\title{
BLAST: A Digital Computer Program for the Dynamic Simulation of the High Temperature Gas Cooled Reactor Reheater-Steam Generator Module
}

R. A Hedrick

J. C. Cleveland

OAK RIDGE NATIONAL LABORATORY

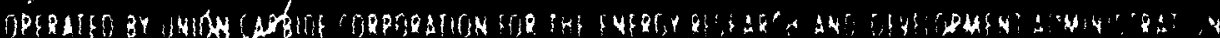


Printed in the United Siates of America. Arailable from National Technical Information Service

U.S. Department oi Commerce

5285 Port Royal Road. Springfield. Virginia 2<!E1

Price Printed Copy \$5.00, Microficite \$2 25

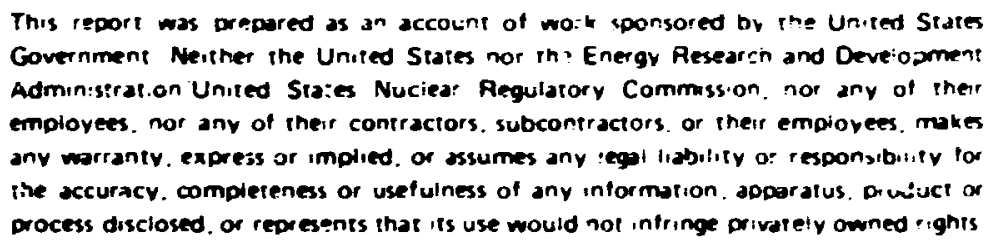

This report was prepared as an account of wo:t sponsored by rese United States Covernment Neither the United States nor th? Energy Research and Deve:opment Administration United Sta:es Nucieat Regulatory Commission. nor any of their employees. nor any of their contractors. subcontractors or their empiovees. makes any warranty. express or implied. or assumes any agal liability of responsibility for the accuracy. completeness or usefulness of any information. apparatus. prinici or process disciosed, or represents that its use would not infringe privalety owned : ghis 
ORNL/MREG/TH-38

NRC-8

Contract No. H-7405-eng-26

BLAST: A DIGITAL COEPUTER PROGRAY FOR THE DYMAMIC SIMULATION OF THE BIGA TEMPERATURE GAS COOLED

REACTOR REAEATER-STEAY GENERATOR MODULE

\author{
R, A. Hedrick \\ J. C. Cleveland \\ Reactor Division
}

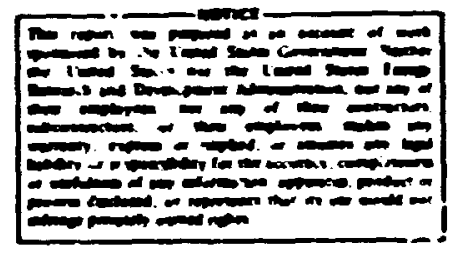

AUGUST 1976

(Th1s work was performed for the U. S. Muclear Regulatory Comission uder Interagency Agreement ERDA No. 40-495-75.)

Manuacr 1pt Completed - June, 24, 197\%

MOTICE: Th1s document contalns inforation of a prelialnary nature and was prepared prianrily for intermal use at the oak Ridge Mational laboratory. It 1s subject to revision or correction and therefore does not represent a final report.

\author{
OAK RIDGE MTIOMAL LABORATORY \\ Oak Ridge, Tennessee 37830 \\ operated by \\ UNION CARBIDE CORPORATION \\ for the \\ ENERGY RESEARCH AND DEVELOPHEIT ADMINISTRATION
}




\section{ACKHONLDGIESTS}

The authors would like to express thefr sincete thonks to S. I. Ball

and J. P. Sanders for their susgestions durting development of oust and co Paula Renfro and J111 secka for chelr patience in preparacion of ti:e report. 
Abstract $\ldots \ldots \ldots \ldots \ldots \ldots \ldots \ldots \ldots \ldots \ldots \ldots \ldots \ldots \ldots \ldots \ldots \ldots \ldots \ldots \ldots \ldots \ldots \ldots \ldots$. vit

Table of nonenclature $\ldots \ldots \ldots \ldots \ldots \ldots \ldots \ldots \ldots \ldots \ldots \ldots \ldots \ldots \ldots \ldots \ldots$

Introduction $\ldots \ldots \ldots \ldots \ldots \ldots \ldots \ldots \ldots \ldots \ldots \ldots \ldots \ldots \ldots \ldots \ldots \ldots \ldots \ldots \ldots$

Scean Generacor Description $\ldots \ldots \ldots \ldots \ldots \ldots \ldots \ldots \ldots \ldots \ldots \ldots \ldots \ldots \ldots \ldots \ldots .1$

Conservat Ion Equetions $\ldots \ldots \ldots \ldots \ldots \ldots \ldots \ldots \ldots \ldots \ldots \ldots \ldots \ldots \ldots \ldots$

Heac Transfer Correlations. Friction Factor Correlations, and Tube Properties ................................. 9

Steady state search technique $\ldots \ldots \ldots \ldots \ldots \ldots \ldots \ldots \ldots \ldots \ldots \ldots \ldots \ldots \ldots \ldots$

Integration Technique for Transient Solution ............... 13

Equetion of State and Thernodynaic Transport Properties ........ 16

ג. Heliv $\ldots \ldots \ldots \ldots \ldots \ldots \ldots \ldots \ldots \ldots \ldots \ldots \ldots \ldots \ldots \ldots \ldots \ldots \ldots \ldots \ldots \ldots \ldots \ldots$

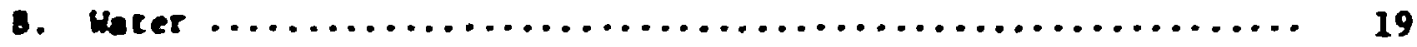

Saple Calcularion $\ldots \ldots \ldots \ldots \ldots \ldots \ldots \ldots \ldots \ldots \ldots \ldots \ldots \ldots \ldots \ldots \ldots \ldots \ldots \ldots$

Plans for Future tee $\ldots \ldots \ldots \ldots \ldots \ldots \ldots \ldots \ldots \ldots \ldots \ldots \ldots \ldots \ldots \ldots \ldots \ldots$

References $\ldots \ldots \ldots \ldots \ldots \ldots \ldots \ldots \ldots \ldots \ldots \ldots \ldots \ldots \ldots \ldots \ldots \ldots \ldots \ldots \ldots \ldots$

Append Ix A. Input Description $\ldots \ldots \ldots \ldots \ldots \ldots \ldots \ldots \ldots \ldots \ldots$

Appendix 8. Input Liscing and Princout of Results for sample Problem ................................. 54 
BLAST sinulates the high cenperature 8 as cooled reactor reheaterstean generator nodule with a nult-node, fixed boundary, homogenous flow sodel. The the dependent conservation of energy, ass, and noEeutur equations are soived by an implicit integration technique. The code contains equation of staze formulions for both heliu and water as well as heat transfer and íriction factor correlations. Normal operational transients and nore severe transients such as those resulting in $10 w$ and/or reverse flow can be simulated. The code calculates helium and water temerature, pressure, flov rate, and tube bulk and wall temperatures at various points within the ceheater-stean generatcr module during the trarisients. BLAST predictions will be conpared with dynanic test resulis obtained from the Fort St. Vrain reactor owned by Public Service of Colorado, and, based on these compariscns, appropriate improvements w11 be made in BLAST. BLAST is written in FORTRAN IV for the IBM $360 / 91$ computer at the Oak Ridge National Laboratory.

Keywords : gas cooled reactors, dyni alc response, programs (computer), once-through steani generacor. 
TABLE OF NOMENCLATURE

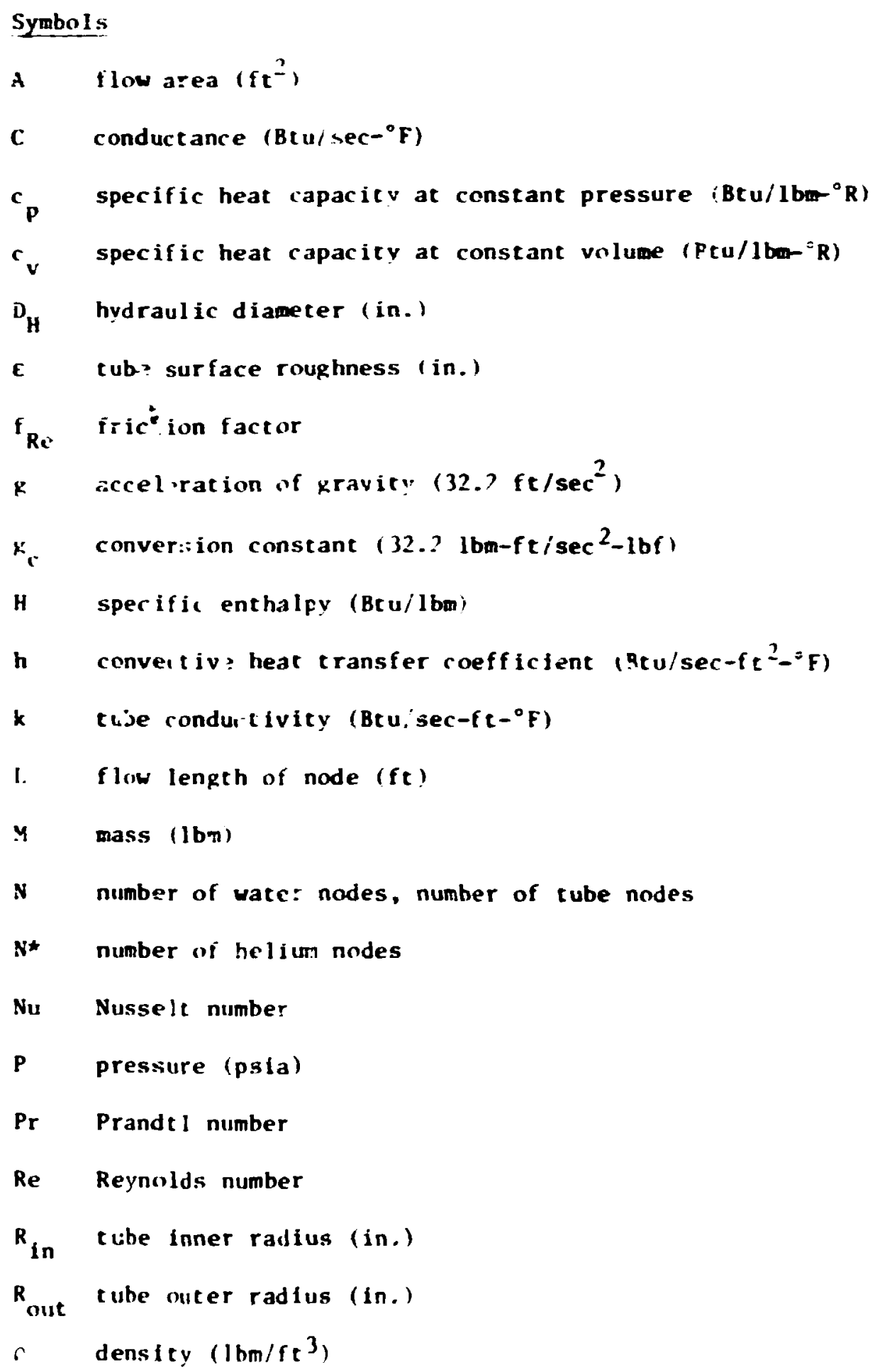




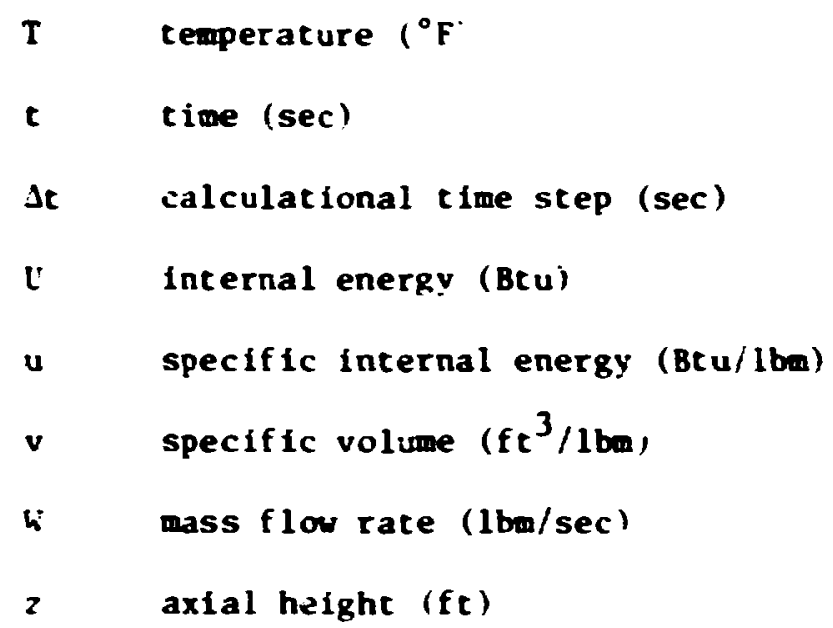

\section{Superscripts}

denotes water node vartable
h denotes helium node vartable
t denotes tube iodt vartable

\section{Subscripts}

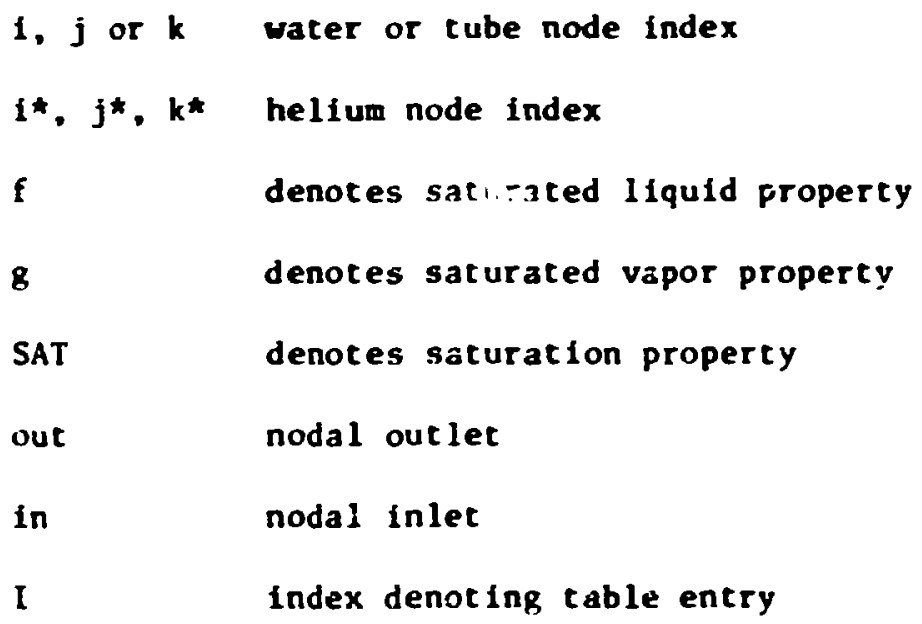


BLAST: A DICITAL COMPLTER PROGRAM FOR THE DYNAMIC SIMLATION OF THE HIGH TEPPERATLRE GAS COOLED

REACTOR REHEATER-STEAY GEIERATOR MODCLE

\author{
R. A. Hedrick J. C. Cleveland
}

\title{
INTRODLCTION
}

BLAST was developed specifically to predict the dynaric resporse of the high temperature gas cooled reactor (HTGR) reheater-steal generator ruduie for use in a system response zode for the HTGR plant. A typical HTCR reheater-stean generator module, developed by the General Atomic r.mpany, is shown in Figure 1. The HTCR utilizes a once-through steam gen-rator. The code is not limited to the specific design show in Figur: 1 and can be used to simulate different desigrs with appropriate input description. The version of BLAST described here is the component simulatior. Slight modifications are required to Incorporate this component simclation into a systex response code.

This report contains a derivation of the integration technique used to solve the conservation equations, a discussion of the heat transfer and friction factor calculations, and of the equation of state formulation both for helium and for water, an input description and a sample problem. A FORTRAN IV listing or deck is avallable upon request.

\section{STEAM GENERATOR DESCRIPTION}

Ide..tical reheacer-ateam generator modules are located in symetric cavities within the prestressed concrete reactor vessel (PCRV) of the. HTCR. The $2000 \mathrm{MW} / \mathrm{t}$ ) HTGR contains four such modules, and the $300 \mathrm{MW}(\mathrm{t})$ 


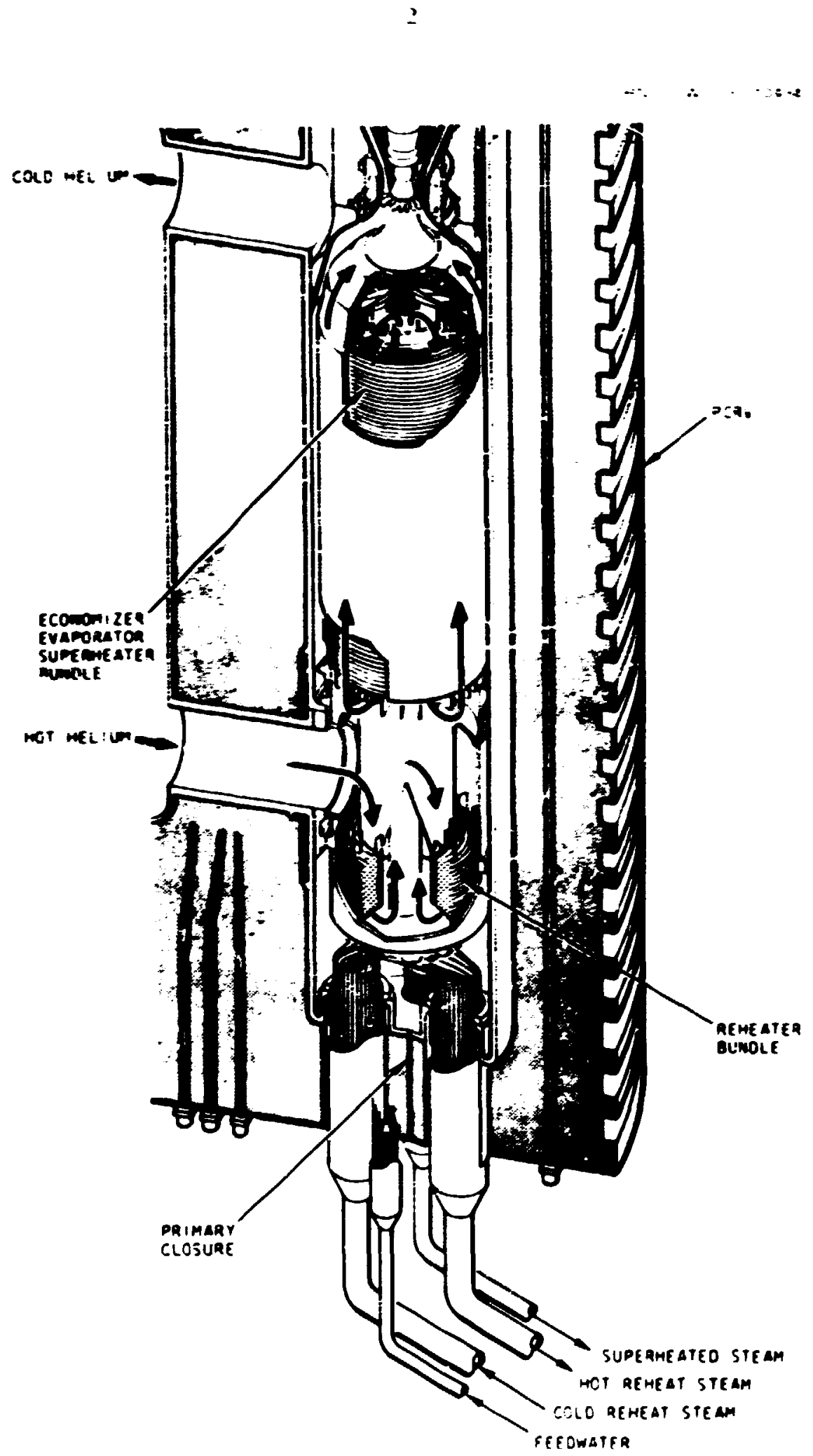

Fig. 1. Large HTGR plant steam gerierator. 
plant cuntains six. Each module is composed of reheater and zain stean tube bundles arranged as stown in Figure 2. The heat exchanger bundles corsist ct gultistar: colls wound in a hellcal arrangesent. Het helium encers the reheater near the boctu af the zoduie, flows down over the reheater tube banks, up through a central duct, and dosn cver the axin steas bundle. The reheater tubes are coiled upward and then dowmard so that the reheat stean flow is fnitially countercurrent and then cocurrent to the heliua flow. The water-stear flow in the gain steas bundle is upard, countercurrert to the heilu flow. Further design details of the sodule shom in figure 1 are indicated in the input to the sample problez iAppendix $B$.

\section{CONSERTATION EQTATIONS}

BlAST solves the cons:rvation of energy, mass, and momentur equai ions for both heifu and vater and the conservation of energy equation for the tube in nodal forn. Figure 2 shows schematically a nodal arrangement represent ing the design show in Figure 1 . Sinze a more detalled nodal structure is often desirable or. the water side than on the hellum side, the code allows for more than one tube metal node to receive heat from a given helium node. Each tube node must have one associated water node. As many as twenty water nodes, twenty hel fum nodes, and twenty tube nodes may be used to represent the four sections reheater, economizer, evaporator, and superheater- of the reheater-steam renerator module. fnother version of the code has been developed which allows as many as 100 water nodes, 100 hellum nodes, and 100 tube nodes and allows parallel flow paths. This version yields nodal temperatures and pressures in sufficlent detall for input to stress analyses. 
ORNL OWG $76235,6 R$

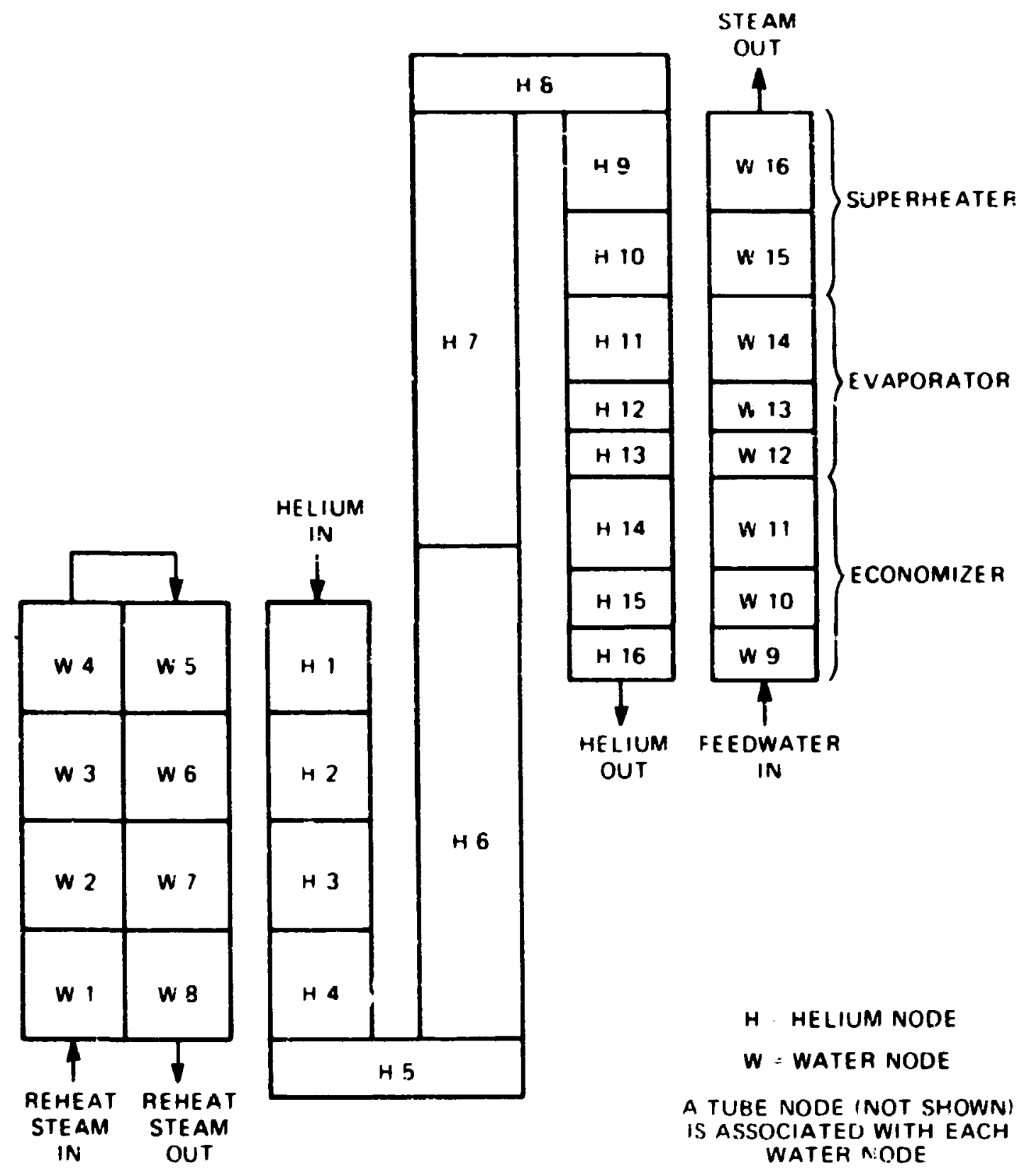

Fig. 2. HTGR reheater-steam generator lodal arrangement. 
Figure 3 shows a general case in which three tube nodes receive heat from one heliur node. The conservation equations for water node $j$ are as follows:

Conservation of energy:

$$
\begin{aligned}
& \frac{d U_{j}^{w}}{d t}=H_{j}^{w} w_{i}^{w}-h_{k j}^{w} w_{j}^{w}+C_{j}^{w}\left(T_{j}^{t}-T_{j}^{v}\right), \\
& \text { (rate of change (net rate of en- (rate of energy } \\
& \text { of nodal inter- ergy flow into transfer via } \\
& \text { nal energy) node via trans- convection and } \\
& \text { port) conduction) }
\end{aligned}
$$

where $H_{j}^{W}$ is the inlet enthalpy to water rode $j$, and $c_{j}^{w}$, the conductance from the tuhe node to the water node, is given by

with

$$
\begin{gathered}
c_{j}^{w}=\frac{2 \pi R_{i n, j} L_{j}^{W}}{\left[\frac{R_{i n, j} \ln \left(\bar{R}_{j} / R_{i n, j}\right)}{k_{j}}\right]+\frac{1}{h_{j}^{W}}}, \\
\vec{R}_{j} \equiv \frac{{ }_{\text {in }, j}+R_{\text {out }, j}}{2} .
\end{gathered}
$$

Conservation of mass:

$$
\begin{aligned}
& \frac{d M_{j}^{w}}{d t}=w_{i}^{w}-w_{j}^{w} \text {, } \\
& \begin{array}{lll}
\text { (rate of change (mass flow rate (mass flow rate } & \\
\text { in nodal mass) into node) } & \text { out of node) }
\end{array}
\end{aligned}
$$

Conservation of momentum:

$$
\begin{array}{lll}
L_{j}^{w} \frac{d w_{j}^{w}}{d t}= & { }^{w} 44 g_{c} A_{j}^{w}\left(P_{j}^{w}-P_{k}^{w}\right) & \rho_{j}^{w} A_{j}^{w}\left(z_{\text {out }, j}^{w}-z_{i n, j}^{w}\right)+ \\
\text { (rate of change } & \text { (net force on fluid } & \text { (gravitational force } \\
\text { of momentum of } & \text { in node due to pres- } & \text { on fluld in node) } \\
\text { f luid in node) } & \text { sure differonce) } &
\end{array}
$$


OANL OWG $76 \cdot 10495$

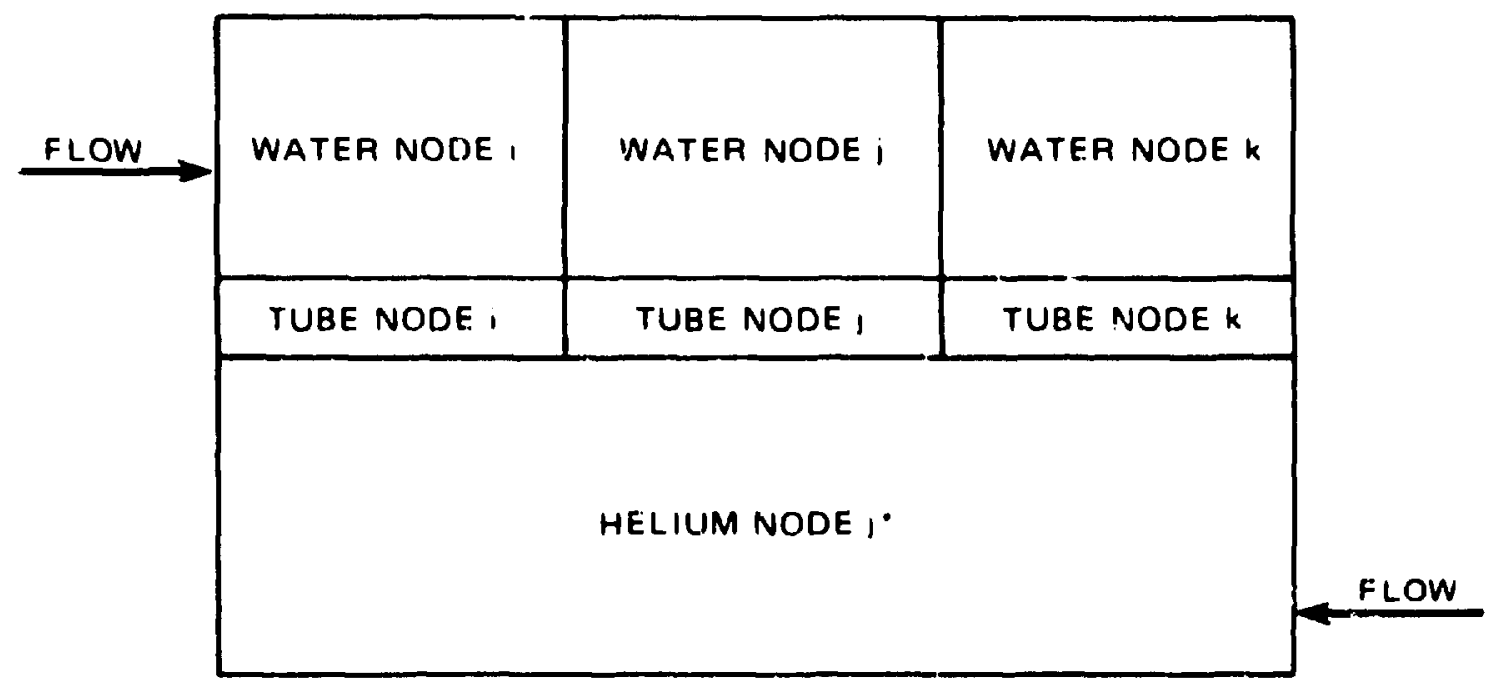

UPSTREAM HELIUM NODE IS I*

DOWNSTREAM HELIUM NODE IS $k$.

Fig. 3. Typical nodal description. 


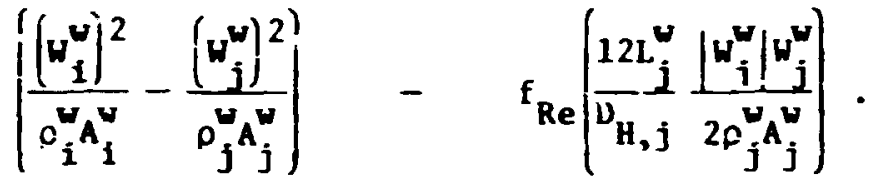

$$
\begin{aligned}
& \text { (rate of momentum inflow (drag due to frictional } \\
& \text { - rate of momentum outflow) force) }
\end{aligned}
$$

Sote that changes of kinetic and potential energy have been neglected in the conservation of erergy equation.

The water node pressures and temperatures are considered $t r$, be functions of internal ene:gy and mass, 1.e.,

$$
P_{j}^{w}=P_{j}^{w}\left(U_{j}^{w}, M_{j}^{w}\right) \quad \text { and } \quad T_{j}^{w}=T_{j}^{w}\left(U_{j}^{w}, M_{j}^{w}\right) \text {. }
$$

Since the typical nodal description show in figure 2 allows more than one tube node to transfer heat with the helfum node, the conservation of energy equation for the helium node $j^{*}$ is:

Conservation of Energy:

$$
\begin{array}{lll}
\frac{d U_{j^{\star}}^{h}}{d t}= & H_{j^{\star}}^{h} w_{j^{\star}}^{h}-H_{k^{\star}}^{h} w_{j^{\star}}^{h} & \sum_{\alpha=1, j, k} c_{j^{\star}, \alpha}^{h}\left(T_{j^{\star}}^{h}-T_{\alpha j}^{t},\right. \\
\text { (rate of change (net rate of ener- } & \begin{array}{l}
\text { (rate of energy transfer } \\
\text { of nodal inter- gy flow into node }
\end{array} \\
\text { nal energy) } & \begin{array}{l}
\text { via transport) } \\
\text { duction) }
\end{array}
\end{array}
$$

where $c_{j^{*}, \alpha}^{h}$ the conductance frum hellum node $j *$ to tube node $\alpha$ (with $\alpha=1, f$, or $k)$ is

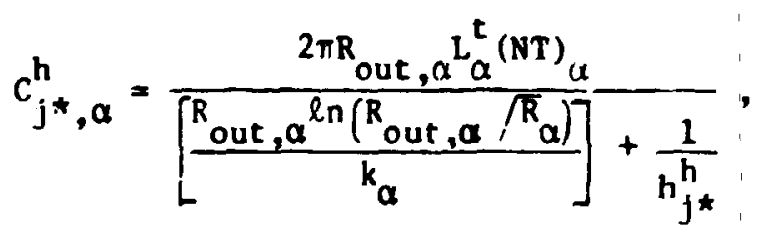


where $L_{\alpha}^{t}$ is the length of tubing in tube node $\alpha$, and (NT) is the number of tube coils which receive heat from the helium node. The summation over $1, j$ and $k$ accounts for the fact that in the typical configuration shown in Figure 3, three tube nodes transfer heat with one helium node. The conservation of mass and momentum equations for helium node $j^{*}$ are similar to those for water node $j$. They are given below for later reference.

Conservation of mass:

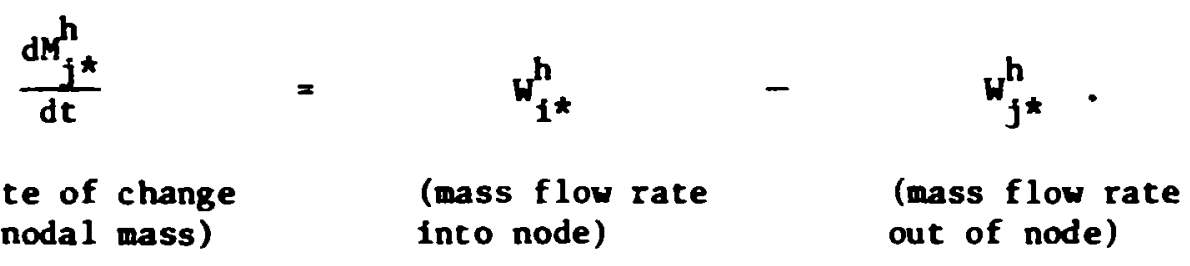

Conservation of momentum:

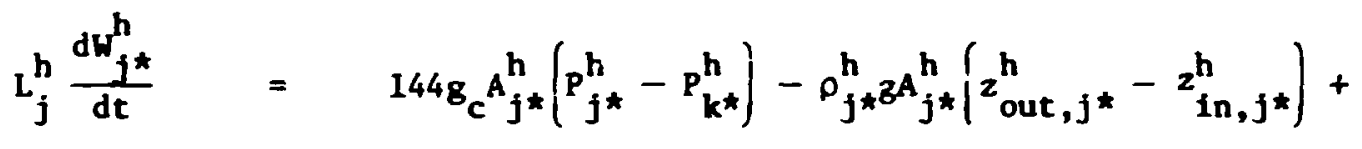

(rate of change (net force on fluid (gravitational force of momentum of in node due to pres- or. fluid in node) fluid in node) sure difference)

$$
\begin{aligned}
& \left(\frac{\left(w_{i^{\star}}^{h}\right)^{2}}{\rho_{i^{\star} A^{\star}}^{h}}-\frac{\left(w_{j^{\star}}^{h}\right)^{2}}{\rho_{j^{A^{*}}}^{h}}\right)-f_{\operatorname{Re}}\left(\frac{12 L_{j^{\star}}^{h}}{D_{H, j^{\star}}} \frac{\left|w_{j^{\star}}^{h}\right| w_{j^{\star}}^{h}}{2 \rho_{j^{\star} A_{j \star}^{h}}^{h}}\right) . \\
& \text { (rate of momentum in- (drag due to fric- } \\
& \text { flow - rate of momentum tional force) } \\
& \text { out f low) }
\end{aligned}
$$

The helium nodal pressures and temperatures are considered to be functions cf nodal Internal energy and mass, 1.e., 


$$
P_{j^{\star}}^{h}=P_{j^{\star}}^{h}\left(U_{j^{\star}}^{h}, M_{j^{\star}}^{h}\right), T_{j^{\star}}^{h}=T_{j^{\star}}^{h}\left(v_{j^{\star}}^{h}, M_{j^{\star}}^{h}\right)
$$

The conservation of energy equation for tube node $j$ is:

$$
\begin{aligned}
& M_{j}^{t} c_{P_{j}}^{t} \frac{d T_{j}^{t}}{d t}=C_{j^{\star}, j}^{h}\left(T_{j^{\star}}^{h}-T_{j}^{t}\right) \quad-C_{j}^{w}\left(T_{j}^{t}-T_{j}^{w}\right) . \\
& \text { (rate of change (rate of heat trans- (rate of heat trans- } \\
& \text { of internal ener- fer from helfum by fer to vatrir by con- } \\
& \text { gy in tube node) conduction and con- duction and convection) }
\end{aligned}
$$

\section{HEAT TRANSFER CORRELATIONS, FRICTION \\ FACTOR CORRELATIOAS AND TUBE PROPERTIES}

In order to solve the conservation equations (Eqs. 1-7), values for convective heat transfer coefficients on both the helium and water side and the tube properties, $p, c_{p}$ and $k$ must be obtained. To obtain the convect ive heat transfer coefficient on the hr.11u side, BLAST uses the modified Grimison correlation' for hel:um flowing over banks of tubes:

$$
N u=B(\text { Re })^{n}(\operatorname{Pr} / 0.69)^{0.33}
$$

where $B$ and $n$ are cabulated in Reference 1 as funct lons of the transverse and longitudinal pitch to diameter ratios. These functions are stored in the code.

For the hellur. side friction factor, the code uses correlations: for flow over banks of tubes based on the cransverse and longleudinal pitch to dianeter ratios and the Reynolds number. Allowance ts made for cube arrangementa chat are partly inline and partly stapkered by 
weighting tla correlations for inline tubes and staggered tubes appropriately.

Various correlations are used to determine the heat transfer coefficient on the water side depending on the water flow regime. These correjacions are listed in Table 1. The correlations for departure from nucleate bolling (DNB) flux, also given in Table 1, are used as trips to deternine when two phase correlations beyond LNB rather than the nucleate bolling correlation should be applied. Trips from other flow regimes are based on quality (e.g., from film boiling to superheat forced convection) or on a comparison of tube wall to bulk fluid temperature drop as calculated by correlations for adjacent flow regimes. For example, if a Dittus-Boelter correlation in the subcooled forced convection flow regime results in a tube wall to bulk temperature drop greater than the Thom nucleate bofling correlation, but the DNS flixx has not been exceeded, the nucleate bolling $h$ at transfer correlation is used.

Friction factors on the water side are obtained from fits to the Fanning friction factor curves. ${ }^{12}$ In the two phase regions, MartinelifNelson two phase multipliers ${ }^{13}$ or Thom modified Martinelli-Nelson two phase multipliers ${ }^{14}$ are applied depending on the pressure. The curvature effects for helfcally wound tubes are also taken into account based on informat tor in Reference 1 .

Presently the code contains density, conductivity and specific heat for three tube types: Carbon steel (SA-210-A1), Incoloy 800 and Croloy (SA-213-T22). Properties for other tube materials could easily be added by the user if necessary. 
Table 1. Heat transfer and DNB flux correlations:

\begin{tabular}{ll} 
Regine & Correlation \\
\hline
\end{tabular}

Subcooled forced convertion

Bittus-Boelter

Two phase
a. Nucleate bolling
Throm $^{3}$
(subcooled and saturated)
b. Transition boiling
McDonough-Milich \& King"
c. Film botling
Dougall Rosenhow 5
or
Groeneve1d 6
Morgan $\stackrel{\text { or }}{?}$ (for low flow)

Superheat forced convection

Dittus-Boe1ter

DNB flux

$$
\begin{aligned}
& W-3^{8}, \text { Jansen-Levy } \\
& \text { or } \\
& \text { B\&H-2 }{ }^{10} \text {, Barnet } t^{11}
\end{aligned}
$$

*These correlations were chosen on the basis that they are acceptable for emergency core cooling system evaluations for light water cooled react ors (10-CFR-50, Appendix K). 


\section{STEADY STATE SEARCH TECHNIQUE}

At the beginning of each run, the code performs a =ceady state sta-ch. The flow rate in each node is input equal to the specified inlet ilow rate so that the steady state conservation of mass equations (2) and (5) are autonatically satisfied. Starting with initial guesses at nodal pressures and enthalpies, the code detemines $\frac{d W}{d t}$ for ea:h helium and water node by evaluating the right hand side of the momentum equations (3) and (6). Unless the correct steady state values of nodal enthalpies and pressures have been supplied, $\frac{d W}{d t}$ will not be zero. Beginning with the inlet nodes to the reheater and main steam bundle, the code next adjusts the nodal pressures so that this time derivative is zero for each node. Using these adjusted pressures and the original enthalpies, the above process is repeated (i.e., $\frac{d W}{d t}$ is computed for each node from equat:ons (3) and (6) and the nodal pressures readjusted to force $\frac{d W}{d t}$ to equal zero) for the ner statcs unt 1 nodal pressures converge.

Next, a guess at nodal tube temperatures is made so that the temperature dependent tube conductivity can be estimated. Heat transfer coefficients fur helium and water nodes are also calculated so that the nodal heat fluxes can be found. These nodal heat fluxes, along with the inlet flow rates and enthalpies to the reheater and main steam oundle are then used to determine nodal outlet enthalples, assuming stiady state. The average nodal enthalpies are then determined and compared wth the previous guesses of nodal enthalpies. If they differ by more than a preset convergence criteria, the code repeats the tteration on nodal pressure discussed in the previnus paraglaph using the new values of nudal enthalpy. This iterative technique is continued unt 1 crivergence 
is achieved on helium and water nodal pressures and enthalpies and on nodal tuhe temperatures.

\section{INTEGRATION TECHNIQLE FOR TRANSIENI SOLLTION}

Defining $N$ to be the number of water nodes and the number of tube nodes and $N^{\star}$ to be the number of helfum nodes, the conservation equations (1-1) can be written in state variable form as

$$
\dot{\mathbf{Y}}(t)=\underline{\mathrm{f}}[\mathbf{Y}(t)],
$$

where $y$ is the $4 N+3 N *$ column vector of state variables:

$y=\left(u_{1}^{w}, \ldots, u_{n}^{w}, M_{1}^{w}, \ldots, M_{n}^{w}, w_{1}^{w}, \ldots, w_{n}^{w}, T_{1}^{t}, \ldots, T_{n}^{t}, u_{1}^{h}, \ldots, u_{n \star}^{h}, M_{1}^{h}, \ldots, M_{n \star}^{h}, w_{1}^{h}, \ldots, w_{n^{\star}}^{h}\right)$, and $\underline{f}[y(t)]$ is the $4 N+3 N *$ column vector of functions determined by the right-hand sifes of equations (1-7). The value of the nth state variable at time $t+\Delta t$, where $\Delta t$ is the computational time step, can be written in terms of state variables at time $t$ by a Iinearized implictit formulation:

$$
y_{n}(t+\Delta t)=y_{n}(t)+(\Delta t) \frac{d y_{n}(t+\Delta t)}{d t}
$$

where, using Eq. 8,

$$
\frac{d y_{n}(t+f, t)}{d t}=f_{n}[y(t+\Delta t)] \doteq f_{n}[y(t)]+(\Delta t) \frac{d}{d t} f_{n}[y(t)] .
$$


Applying the chain rule to the $\frac{d}{d t} f_{n}[y(t)]$ term gives

$$
{\frac{d y_{n}}{d t}}^{(t+\Delta t)} \doteq f_{n}[y(t)]+(\Delta t) \sum_{m=1}^{4 N+3 N{ }^{*}} \frac{\partial f_{n}}{\partial y_{m}}[y(t)] \frac{d y_{m}(t)}{d t}
$$

Approximating $\frac{d y_{m}(t)}{d t}$ in Eq. 11 by $\frac{y_{m}(t+\Delta t)-y_{m}(t)}{\Delta t}$ and substituting

Eq. 11 into Eq. 9 gives

$$
\Delta y_{n}-(\Delta t) \sum_{m=1}^{4 N+3 N *} \frac{\partial f_{n}}{\partial y_{m}}[\underline{y}(t)]{\Delta y_{m}}_{m}=(\Delta t) f_{n}[y(t)],
$$

where $\Delta y_{n} \equiv y_{n}(t+\Delta t)-y_{n}(t)$.

This equation can be written in terms of the Jacobian matrix, $J(y(t))$, as

$$
[\underline{\underline{I}}-(\Delta t) \underline{J}\{\mathbf{y}(t)]] \Delta \underline{y}=(\Delta t) \underline{f}[\underline{y}(t)],
$$

where $\stackrel{I}{\rightleftharpoons}$ is the identity matrix, and the lmth element of $\mathrm{J}$ is $\frac{\partial \mathrm{f}_{\ell}}{\partial \mathrm{y}_{\mathrm{m}}}$. Next, each of the conservation equations $(1-7)$ is cast in the form of Equation 12. For example, the conservation if energy equation for water node $j$ (Eq. 1) becomes, $\Delta U_{j}^{w}-(\Delta t)\left[H_{j}^{w} \Delta W_{i}^{w}-H_{k}^{w} \Delta w_{j}^{w}+c_{j}^{w}\left(\Delta T_{j}^{t}-\frac{\partial T_{j}^{w}}{\partial U_{j}} \Delta U_{j}^{w}-\frac{\partial T_{j}^{w}}{\partial H_{j}} \Delta M_{j}^{w}\right)\right]=(\Delta t) \frac{d U_{j}^{w}(t)}{d t}$

Note that the two partial derivitive terms appear because the nodal water temperature, $T_{j}^{W}$, is considered to be a function of the state variables, $U_{j}^{W}$ and $M_{j}^{W}$. Note also that $H_{j}^{W}$ and $H_{k}^{W}$, the nodal inlet and 
out let enthalpies, and $c_{j}^{w}$, the conductance from the tube node to the water, have been assumed constant during st so that, for instance, there is no $3 \mathrm{H}_{\mathrm{j}}^{\mathrm{w}} / \mathrm{x}_{\mathrm{j}}^{\mathrm{w}}$ term in Equation 13. Inlet and out let enthalpies and conductances are recomputed at the end of each time step.

Writing the moment um Equations (3) and (6) for water and helium in the form of Equation (12) introduces $\frac{\partial P}{\partial V}, \frac{\partial P}{\partial M}, \frac{\partial F}{\partial U}, \frac{\partial P}{\partial M}$ terms. However, terms containing the derivatives of density are orders of magnitude smaller than terms containing the derivatives of pressure and are, cherefore, neglected. Also, the friction factors are assumed constant during st and are recomputed at the end of each time step. When all of the conservation Equations (1-7) have been written in the implicit form of Equation (12), terms containing $\Delta \mathrm{L}^{W}, \Delta \mathrm{M}^{\mathrm{W}}, \Delta \mathrm{W}^{\mathrm{W}}$, $\ni T^{w} / \partial v, \partial T / \partial M, \partial P \omega / \partial v$, and $\partial P \omega / \partial M$ for water nodes, similar terms for the helfum nodes, and $\Delta T^{t}$ for the tube nodes have been introduced. The $\Delta \mathrm{U}^{\mathrm{W}}, \Delta \mathrm{L}^{\mathrm{h}}, \Delta \mathrm{M}^{\mathrm{W}}$, and $\Delta \mathrm{M}^{\mathrm{h}}$ terms can be eliminated from the $4 \mathrm{~N}+3 \mathrm{~N}^{*}$ equitions by algebraic manipulation, leaving a $2 N+N^{*}$ system of equations that may be written

$$
\underline{A} \underline{\mathbf{v}}=\underline{\mathbf{b}} \text {. }
$$

where $\mathrm{v}$ is the $2 \mathrm{~N}+\mathrm{N}$ column vector

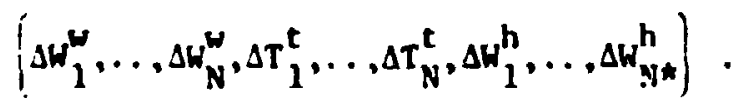

$\underline{A}$ and $\underline{b}$ are determined by the values, at time $t$, of heat transfer coefficlents, tube properties, friction factors, enthalpies the deriva: ives 
of pressure and temperature with respect to internal energy and mass and the values of the right-hand sides of the conservation Equations $(1-T)$. Once the components of $\underline{A}$ and $\underline{b}$ have been determined, Equation (14) is solved by inverting $\stackrel{A}{=}$. From the resulting values of $\Delta W^{W}$ and $\Delta W^{\text {h }}$ for the water and helium nodes and $\Delta T^{t}$ for the tube nodes $\Delta U^{W}, \Delta \mathrm{C}^{\mathrm{h}}, \Delta \mathrm{M}^{\mathrm{W}}$, $\Delta M^{h}$ can be determined by back substitution into the conservation equations which were witten in the form of Equation 12.

Results obtained using the implictt integration technique described ahove agree quite well with results obtained using an explicit Euler integration technique. For HTGR transients, which tend to be "slow"from a few minutes to an hour or two in duration--the implicit integration technique is judged superior since explictt terhniques are 1 imfted to small time steps by stability considerations. A discussion of the stability and error propagation for the implicit technfque is given in Reference 15 .

The version of the code which allows up to 100 helium nodes, 100 water nodes, and 100 tube nodes to frovide the detailed temperature and pressure distributions required for stress analysis employs the explicit integration technique. The implictt technique is not suttable for simulations using this large number of nodes because it requires inversion of the A matrix (Eq. 14).

\section{EQUATION OF STATE AND THERMODYNAMIC TRANSPORT PROPERTIES - HELIUM}

In order to calculate terms in the $\stackrel{A}{\underline{A}}$ matrix and the $\underline{b}$ vector in Equation (14), the helium state and thermodynamic transport properties must be found. The solution at $t$ ime $t$ yields values of $U(t)$ and $M(t)$ 
for each helium note. From internal energy and mass, the code determines temperature and pressure and their derivatives with respect to internal energy and mass as well as the transport properties $\mu, c_{p}$ and $k$. The helium nodal temperature, in degrees Rankine, is found by

$$
T=\frac{1}{c_{v}} u \text {, }
$$

where $u$ is specific internal energy $\left(B t u / 1 b m-{ }^{\circ} R\right)$ and $c_{v}$ is the specific heat at constant volume $\left(.75 \mathrm{Btu} / 1 \mathrm{bm}{ }^{\circ} \mathrm{R}\right)$. Liodal pressure follows from the helium equation of state (Ref. 16).

$$
P=\frac{1}{\frac{B}{\rho T}-\frac{A}{T^{1.2}}} \text {, }
$$

where $A$ and $B$ are constants. The derivatives of temperature with respect to internal energy and mass are found from Equation (15):

$$
\left.\frac{\partial T}{\partial \mathrm{U}}\right|_{M}=\left.\frac{1}{M} \frac{\partial T}{\partial u}\right|_{\rho}=\frac{1}{M c_{v}},
$$

and

$$
\begin{aligned}
\left.\frac{\partial T}{\partial M}\right|_{U} & =\left.\frac{1}{v} \frac{\partial T}{\partial \rho}\right|_{u \rho}, \\
& =\left.\frac{1}{v} \frac{d T}{d u} \frac{\partial u}{\partial \rho}\right|_{u \rho}, \\
& \left.=\frac{1}{V c} \frac{\partial}{\partial \rho}\left(\frac{u \rho}{r}\right)\right)\left.\right|_{u \rho}, \\
& =-\frac{1}{V c_{v}}\left(\frac{u}{n}\right) .
\end{aligned}
$$


The derivatives of pressure with respect to internal cnergy and mass are obtained as follows:

$$
\left.\frac{\partial P}{\partial U}\right|_{M}=\left.\frac{1}{M} \frac{\partial P}{\partial u}\right|_{\rho}=\left.\frac{1}{M} \frac{d T}{d u} \frac{\partial P}{\partial r}\right|_{\rho} .
$$

From Equaiion (16)

$$
\left.\frac{\partial P}{\partial T}\right|_{\rho}=\frac{P^{2}}{T}\left[\frac{B}{\rho T}-\frac{1.2 A}{T^{1.2}}\right] \text {, }
$$

so

$$
\left.\frac{\partial P}{\partial U}\right|_{M}=\frac{1}{M c_{v}} \frac{P^{2}}{T}\left[\frac{B}{\rho T}-\frac{1.2 A}{T^{1.2}}\right] \text {. }
$$

Finally

$$
\left.\frac{\partial P}{\partial M}\right|_{U}=\left.\frac{1}{V} \frac{\partial P}{\partial \rho}\right|_{u \rho}
$$

Equations (15) and (16) can be combined to give

$$
P=\frac{1}{\frac{B c_{v}}{\rho u}-\frac{A\left(\rho c_{v}\right)^{1.2}}{(\rho u)^{1.2}}} \text {, }
$$

and it follows that

$$
\left.\frac{\partial P}{\partial M}\right|_{U}=\frac{p^{2}}{V} \frac{(1.2) A}{\rho T^{1.2}}
$$

The thermodynamic iransfort properties are obtained from the following fits to data in the indicated references

$$
\begin{aligned}
\mu= & 5.9178 \times 10^{-4} \mathrm{~T}^{0.7}(1 \mathrm{bm} / \mathrm{ft}-\mathrm{hr}), \text { (Ref. 16), } \\
k_{\text {he }}= & 1.29 \times 10^{-3} \mathrm{~T}^{0.674}+8.15 \times \\
& 10^{-4}(\mathrm{P}-14.69)^{0.28}\left(\mathrm{Btu} / \mathrm{hr}-\mathrm{ft}-{ }^{\circ} \mathrm{R}\right),(\text { Ref. 17), }
\end{aligned}
$$




$$
c_{p}=1.2462 \frac{B r u}{1 b_{m}^{\circ} R},(\operatorname{Ref} .16),
$$

where $T$ is in degrees Rankine, and $P$ is psia.

\section{EQUATION OF STATE AND THERMODYNAMIC \\ TRANSPORT PROPERTIES - WATER}

Determining the state and transport properties for each water node is somewhat more involved than for helium. The water equation of state is determined by data from the 1967 ASME Steam Tables (Ref. 18), that is stored in BLAST in tabular form. For a series of values of saturation pressure the tables contain the corresponding values of $\rho_{f}, \rho_{g}, u_{f}, u_{g}$, and $\mathrm{T}_{\mathrm{SAT}^{-}}$. In the subcooled region the code also stores

$$
\left.\frac{\partial u}{\partial P}\right|_{\rho},\left.\frac{\partial h}{\partial F}\right|_{\rho},\left.\frac{\partial T}{\partial P}\right|_{\rho},
$$

and in the superheat region, the code stores

$$
\left.\frac{\partial P}{\partial u}\right|_{\rho},\left.\frac{\partial h}{\partial P}\right|_{\rho},\left.\frac{\partial T}{\partial P}\right|_{\rho} \cdot
$$

This information was obtained from References 19 and 20. The thermodynamic transport properties of viscosity, conductivity, specific heat and Prandt 1 number ace ietermined from fits to the 1967 ASME steam tables.

The code applies interpolation and iteration techniques to calculate pressure, temperature and the required derivatives using the above information from values of specific internal energy, $u$, and density, $p$, known at time $t$. In the single phase regions the techniques are basically those presented in Reference 20. 
The first step in the pressure search is to compare the density, to the critical density, and the specific Internal energv, $u$, to the saturated specific internal energy, "SAT, at the known density $\rho$. The value of $u_{\text {SAT }}$ is calculated by interpolation on density. From this, it can be determined shether the water is in a liquid, two phase or vapor state.

If the water is in the liquid phase, the saturation pressure, PSAT' and the derivative, $\left.\frac{\partial P}{\partial u}\right|_{C}$ at the known density, are determined by linear ficerpolation on density from data stored in the tables. Then the pressure, $P$, is found from

$$
\mathbf{P}=\mathbf{P}_{\text {SAT }}+\left.\frac{\partial P}{\partial u}\right|_{\rho}\left(u-u_{\text {SAT }}\right) .
$$

The enthalpy follows since $h=u+P / \rho$. Nodal temperatures are next determined using interpolated values from the tables of $T_{S A T}$ and $\left.\frac{\partial T}{\partial P}\right|_{\rho}$ at the known density:

$$
T=T_{\text {SAT }}+\left.\frac{\partial T}{\partial P}\right|_{\rho}\left(P-P_{S A T}\right) .
$$

To calcu'ate $\left.\frac{\partial P}{\partial \rho}\right|_{u \rho}$, recall that pressure may be considered a function of specific internal energy and density, i.e.,

$$
P=P(u, \rho) .
$$

Let $\rho_{\mathrm{I}}$ and $\rho_{\mathrm{I}+1}$ be the densitfes stored in the tables that brarket the known density, $\rho$, as shown on the constant density lines in the pressureenthalpy diagram, Figure 4. Values of pressure at densities $p_{1}$ and $\rho_{1+1}$ 


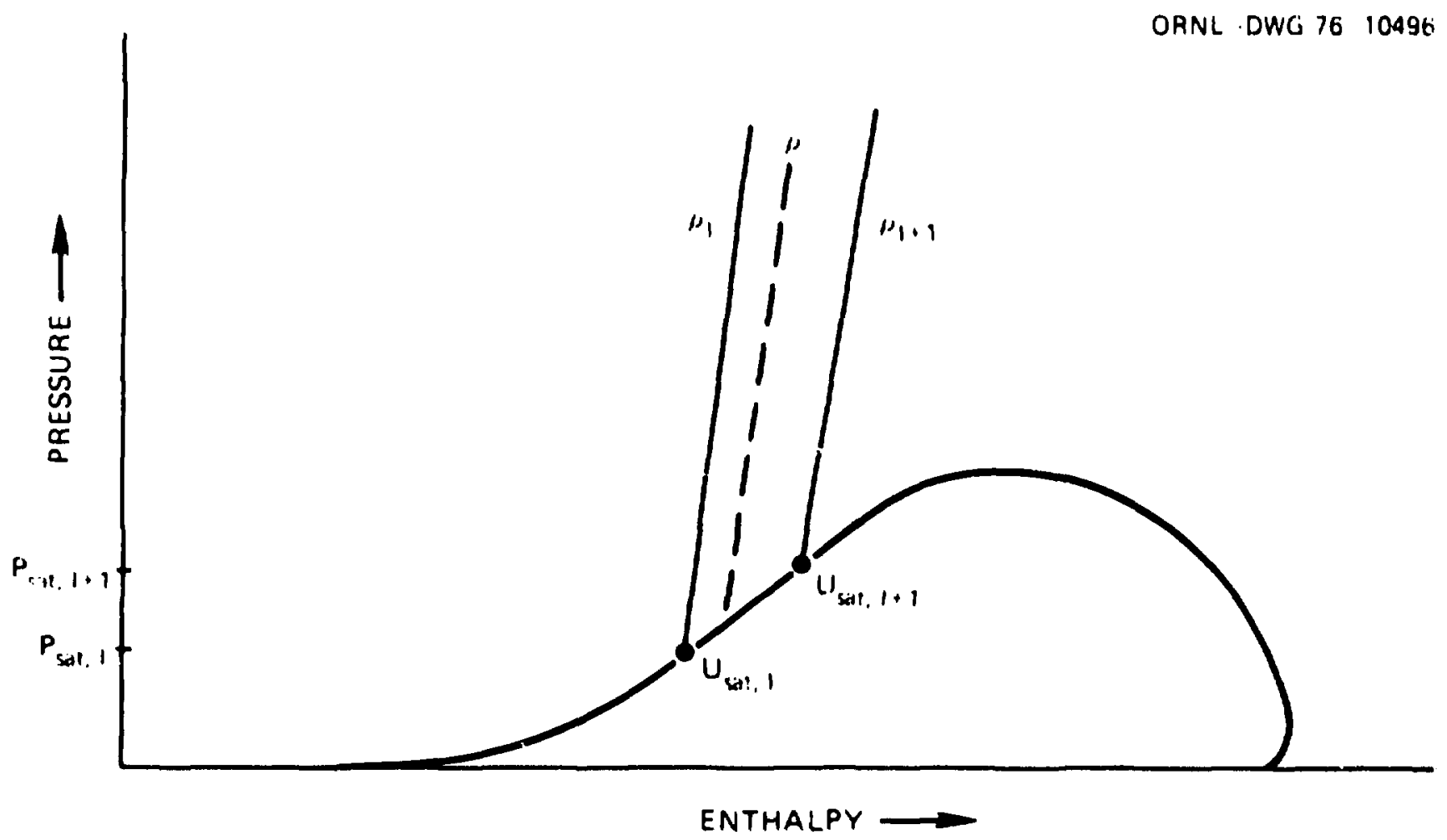

Fig. 4. Pressure vs enthalpy for water. 
with a constant product of internal energy and density are determined

$$
P\left(u, v_{I}\right)=P_{\text {SAT,I }}+\left.\left(u-u_{\text {SAT, I }}\right) \frac{\partial P}{\partial u}\right|_{\rho_{I}} \text {. }
$$

and

$$
P\left(\frac{\rho_{I}}{\rho_{I+1}}, \rho_{I+1}\right)=P_{S A T, I+1}+\left.\left(\frac{\rho_{I}}{P_{I+1}}-u_{S A T, I+1}\right) \frac{\partial P}{\partial u}\right|_{\rho_{I+1}} \text {. }
$$

where the variables subscripted with $I$ and $I+1$ are found in the tables.

Then

$$
\left.\frac{\partial P}{\partial \rho}\right|_{u \rho} \div \frac{P\left(\frac{u_{I}}{\rho_{I+1}}, \rho_{I+1}\right)-P\left(u, \rho_{I}\right)}{\rho_{I+1}-\rho_{I}}
$$

The value of $\left.\frac{\partial T}{\partial o}\right|_{u p}$ is calculated next usir, the values of pressure, deterained in Equations (22) and (23), and values of $T_{\text {SAT, I }}, T_{\text {SAT, I+1 }}$, $\left.\frac{\partial T}{\partial P}\right|_{\rho_{I}}$ and $\left.\frac{\partial T}{\partial P}\right|_{p_{I+1}}$ from the tables, $1 . e$.

$$
T\left(u, \rho_{I}\right)=T_{S A T, I}+\left.\frac{\partial T}{\partial P}\right|_{\rho_{1}}\left[P\left(u, \rho_{I}\right)-P_{S A T, I}\right] \text {, }
$$

and

$$
\tau\left(\frac{u \rho_{I}}{\rho_{I+1}}, \rho_{I+1}\right)=T_{S A T, I+1}+\left.\frac{\partial T}{\partial P}\right|_{\rho_{I+1}}\left[P\left(\frac{u \rho_{I}}{\rho_{I+1}}, o_{I+1}\right)-P_{S A T, I+1}\right] .
$$

Then

$$
\left.\frac{\partial T}{\partial \rho}\right|_{u \rho}=\frac{T\left(\frac{u \rho_{I}}{\rho_{I+1}}, \rho_{I+1}\right)-T\left(u, \rho_{I}\right)}{\rho_{I+1}-\rho_{I}} .
$$


The remainine teaperature derfvat Ive can br written

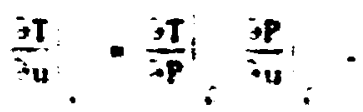

Both of the terax on the right-hand side can be deteralned by Interpolathor on density in the tables.

A very xisflat technlque to thet described above for the state search for the liquid phase is tollowed if the water is in the vapor phase.

In the two phase recion, a different sestch cechnique is used to Ind cemperature. pressure, and the requited derlvat lves froe known Internal enerky and density. Lerating on nodal pressure, two values of pressure. $P_{a}$ and $P_{b}$. are found such that the corresponding specif Ic volumes. $v_{a}$ and $v_{B}$, bracket the knom speciflc volue $v^{\prime}=\frac{1}{i}, 1 . e .$,

$$
v_{0}<v<v_{8}
$$

aind are as close to $v$ as desired. 1.e.

$$
|v-v|<\varepsilon \text { and }\left|v_{3}-v\right|<\varepsilon \text {. }
$$

where $\varepsilon$ is a preset convergence. The values of $v_{u}$ and $v_{B}$ are decermined from $P_{Q}$ and $P_{B}$ by, e.g...

$$
v_{a}=v_{f}\left(p_{a}\right)+\frac{u+P_{a}-h_{f}\left(P_{a}\right)}{h_{f_{R}}\left(P_{a}\right)} \cdot v_{f_{g}}\left(p_{a}\right) \text {. }
$$


where $u$ and $v$ are known, and the saturation properties at $P_{Q}$ and $P_{B}$ are deternined by incerpolation on prassure using the tables. Having found $v_{0}$ and $v_{8}$ wich jracket $v$ and satisfy the restristions in Equation 27 , the pressure corresponding to the known $u$ and $v$ is found by interpolation:

$$
P=P_{a}+\frac{\left(v-v_{a}\right)}{\left(v_{B}-v_{a}\right)} *\left(P_{B}-P_{a}\right)
$$

Now the saturation properties at $P$ can be deterained.

The requirid derivatives, $\left.\frac{\partial P}{\partial u}\right|_{c},\left.\frac{\partial P}{\partial p}\right|_{u p},\left.\frac{\partial T}{\partial u}\right|_{\rho}$ and $\left.\frac{\partial T}{\partial \rho}\right|_{u p}$, in the two phase region can now also be determined. The first of these is found from the relactoo

$$
\left.\left.\left.\frac{\partial P}{\partial u}\right|_{\rho} \frac{\partial u}{\partial \rho}\right|_{P} \frac{\partial o}{\partial P}\right|_{u}=-1
$$

since

$$
\left.\frac{\partial \rho}{\partial u}\right|_{P}=-\left.\frac{1}{v^{2}} \frac{\partial v}{\partial u}\right|_{P}=-\frac{1}{v^{2}} \frac{v_{f_{g}}}{u_{f g}}
$$

and

$$
\left.\frac{\partial \rho}{\partial P}\right|_{u}=-\frac{1}{v^{2}} \frac{\left(v_{\beta}-v_{\alpha}\right)}{\left(P_{B}-P_{\alpha}\right)}
$$

it follows that

$$
\left.\frac{\partial P}{\partial u}\right|_{\rho}=-\frac{v_{f_{B}}}{u_{f_{B}}} \frac{\left(P_{B}-P_{\alpha}\right)}{\left(v_{B}-v_{Q}\right)}
$$

To find the other derivative of pressure, $\left.\frac{\partial P}{\partial \rho}\right|_{u \rho}$, Eq. (29) can be comblned with 


$$
\left.\left.\left.\frac{\partial P}{\partial \mathcal{F}}\right|_{u f} \frac{\partial F}{\partial(u c)}\right|_{P} \frac{\partial(u F)}{\partial P}\right|_{C}=-1 .
$$

to obtain

$$
\left.\frac{\partial P}{\partial c}\right|_{u p}=\left.\frac{\partial P}{\partial c}\right|_{u}-\left.\frac{u}{c} \frac{\partial P}{\partial u}\right|_{f} .
$$

The derivatives on the right-hand side come from Equations (30) and (31).

Since remperature in the two phase region is a function of pressure only, the derivatives of temperature follow from the derivatives of pressure in the following way:

$$
\left.\frac{\partial T}{\partial \rho}\right|_{u \rho}=\left.\left|\frac{d T}{d P}\right|_{\text {SAT }} \frac{\partial P}{\partial \rho}\right|_{u \rho},
$$

and

$$
\left.\left.\frac{\partial T}{\partial u}\right|_{\rho}=\mid \frac{d T}{d P}\right)\left._{S A T} \frac{\partial P}{\partial u}\right|_{\rho},
$$

where

$$
\left(\frac{\mathrm{CT}}{\mathrm{dP}}\right)_{\text {SAT }} \doteq \frac{\mathrm{T}_{\text {SAT, I }}-\mathrm{T}_{\text {SAT, I-1 }}}{\mathrm{P}_{\text {SAT, I }}-\mathrm{P}_{\text {SAT, I-1 }}} .
$$

${ }_{\text {SAT, I }}$ and $P_{\text {SAT, I-1 }}$ are the pressures in the tables that bracket $P$, and $T_{\text {SAT, I }}$ and $T_{\text {SAT, I-1 }}$ are the corresponding saturation temperatures.

\section{SAMPLE CALCLLATION}

The sample caiculation presented in this section is intended to illustrate the use and features of BLAST. This calculation simulates the dynamic response of the reheater-steam generator module to a reactor 
trip froe 100: power. The nodal arrangenent shown in F:R. I was used for this saple problem. Tine dependeni boundary conditions required as Input to the component simulation were derived from printout to a saple problew supplied with the General Atonic TAP progran' which sinulates the ATCR nuclear stem supply systen. Input Instructions for BLAST are given in Appendix $A$, and a list Ing of the user supplied subroutines, the Input data card Images and sample transient printout for this saple calculation are given In Appendix B. Plots generated by BLAST for the reactor trip are included in this section. The IBH $360 / 91$ CPU tine required for this saple calculation was $0.2 \mathrm{sec} / \mathrm{t}$. A description of the event sequences corresponding to reactor cooldown using the reheater-stean generator modules following a reactor trip Is given in Reference 22. The sequence of events for this sample proble are quice sinilar and are sumarized below. The signal for reactor trip causes the control rods to be rapidly Inserted intc the core. The plant control systee ramps the feeduater flow down to 25 ; at a rate of 6.57 per sec as show in Fig. 5. The heliu flow (Fig. 6) is also reduced by the plant control system during the intelal part of the transient to -277 and then increases as the control systew increases the circulator rpa in an attempt to maintain the main steam temperature at a preset value. Upon initiation of the reactor trip, this high pressure turbine throttle valve area is decreased, resulting in an increase in main steam pressure as shown in Fig. 7. Two alnutes after the reactor is tripped, a turbine trip occurs, and the steam generator outlet pressure remains essentially constant at 2603 psia as the steam is discharged to the main steam bypass system. 
The reheater heliur inlet temperature is show in Fig. 8, and tice ialculated stear. generacor heliur. "ut lot terperatire is shown in Fik. Y. This wut let iemperature inftally decteases vitn the decreasing inlet cemperature and then peaks again at 3 in sec due to the peak in the helium flow rate , Fig- hl. The twa in scean out let temperature is shmm in Fik. 10. The sall oscillations shown here are due to changes in flow regime, and the resultin: rlanke in the water side heat transfer coefficients, in the evaporator and superheater nodes. Snte that wet steam is emitted from the steam Renerator irom $395 \mathrm{sec}$ to 550 sec at Wich tine the stean generat or is completely flooded.

To illustrate ane capabilities of the code, the cemperatures, heat transfer coeficients, and heat fluxes for the first superheater section showr in Fig. 2 (represented by nudes $H 10, k 15$ and $T 15)$ were plotted

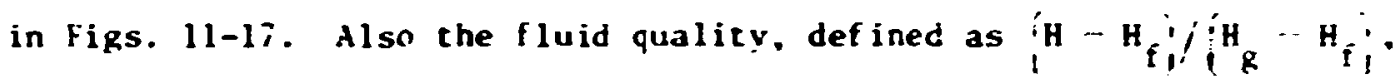
in water node 15 is plotted in Figs. 18-a and 18-b. Figures 12 and 18-a show that this first superheater section contains wet steam of decreasing quality from -100 sec to $-490 \mathrm{sec}$. At $400 \mathrm{sec}$, the fluid quality has declined sufficient ly such that the flow regime changes from a film boiling regime to a nucleate boiling regime with a considerab!; higher heat transfer coefficient (Figs. 16-a and 16-b). The resultant large increase in heat flux (Figs. 17-a and 17-b) drives up the quality (Figs. 18-a and 18-b) causing a roturn to the film boiling regime. This lowers the heat transfer coefficient and therefore the heat flux causing the qualicy to decrease, thercby producing the oscillation in quality, heat Iransfer coefficient, and heat flux shown in the figures. The oscillatinns in fluid quality in water node 15 from -150 sec to 180 sec are the 


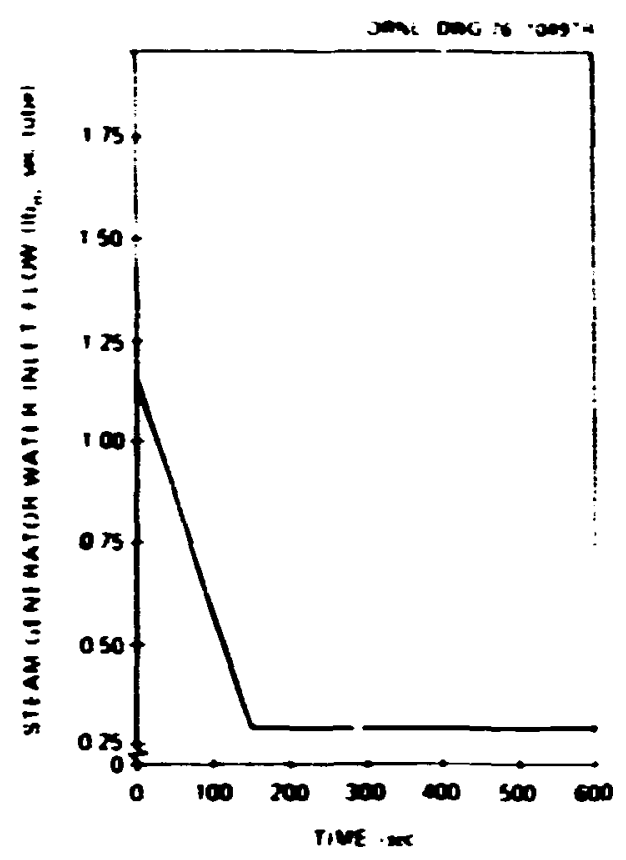

Fig. 5. Sted generator water inlet flow following a reactor trip.

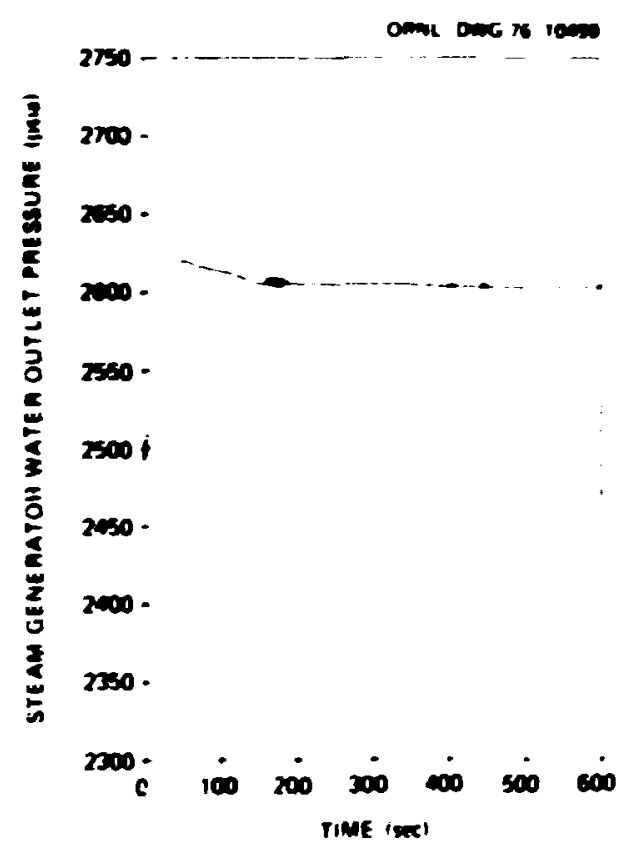

F18. 7. Steam generator water outlet pressure following a reactor trip.

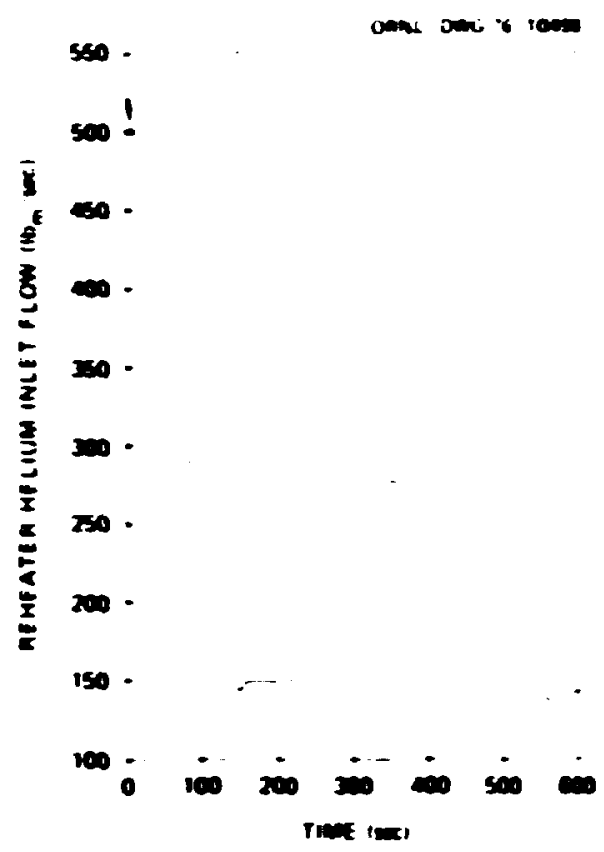

Fig. 6. Reheater helfum inlet flow following a reactor trip.

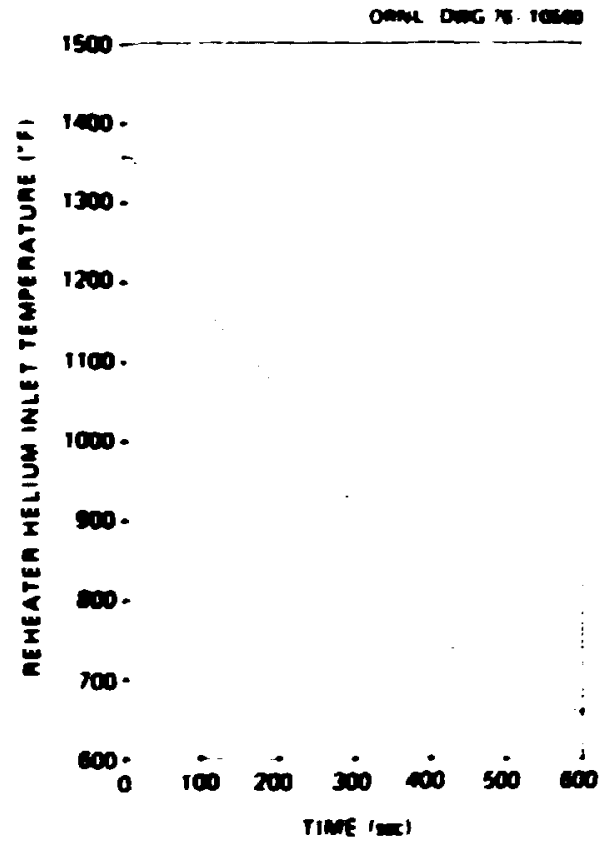

Fig. 8. Reheater tellum inlet temperature following a reactor $t=i p$. 


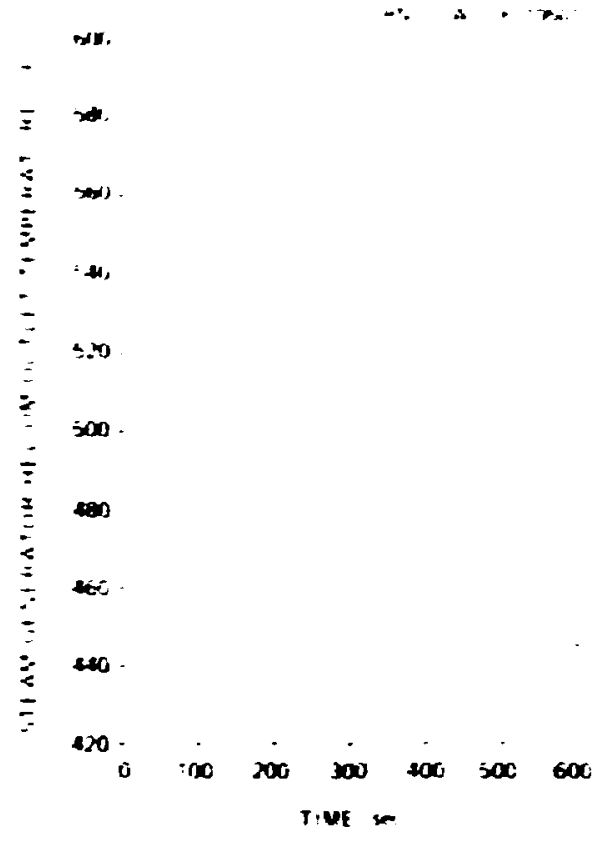

Fig. 9. Steam generator helium out let temperacure following a reactor trip.

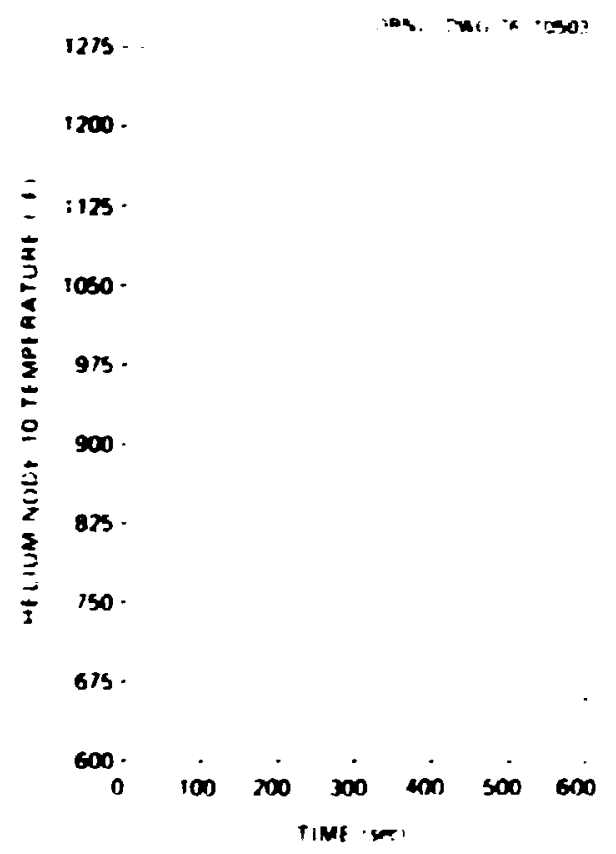

rig. 11. Helium node 10 cemper... fnllowing a reactor trip.

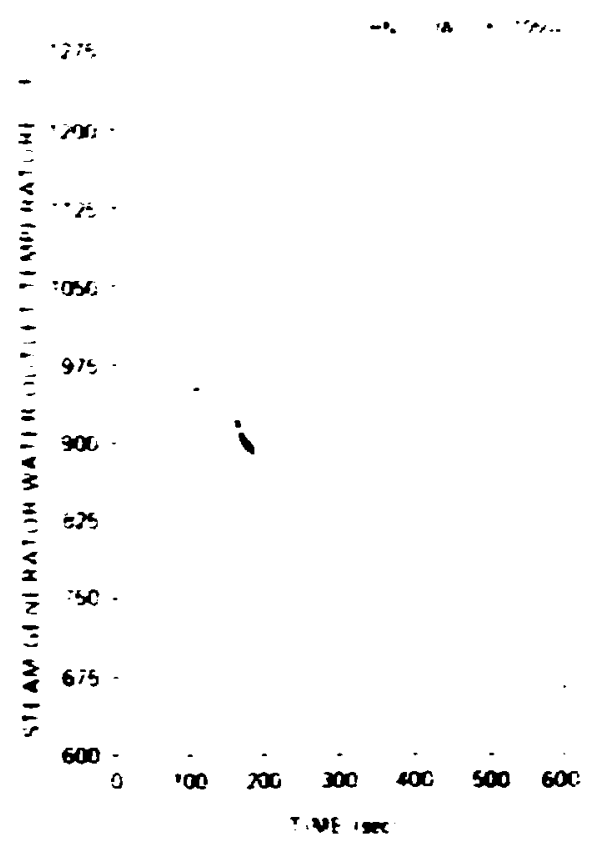

Fig. 10. Jteam generator water outlet cemperature following a reactor trip.

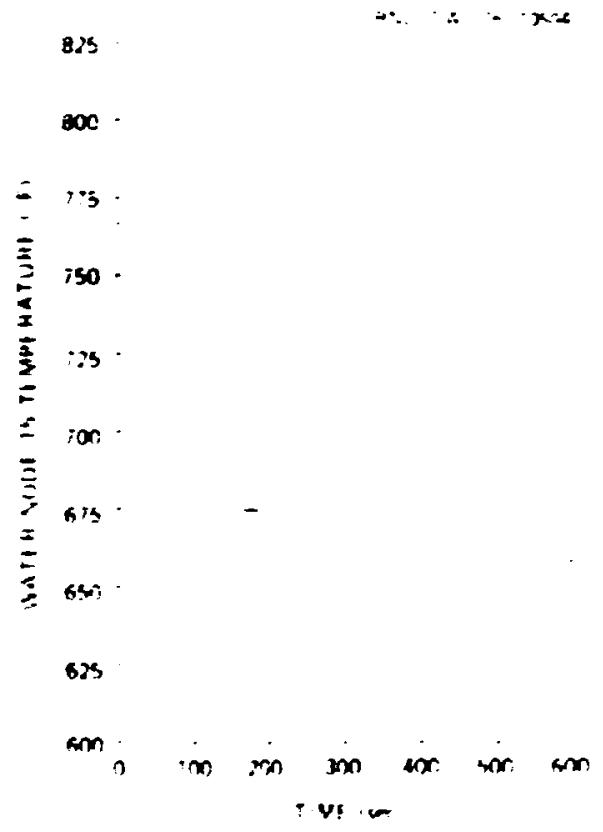

Fig. 12. iater node 15 temperature following a reactor trip. 


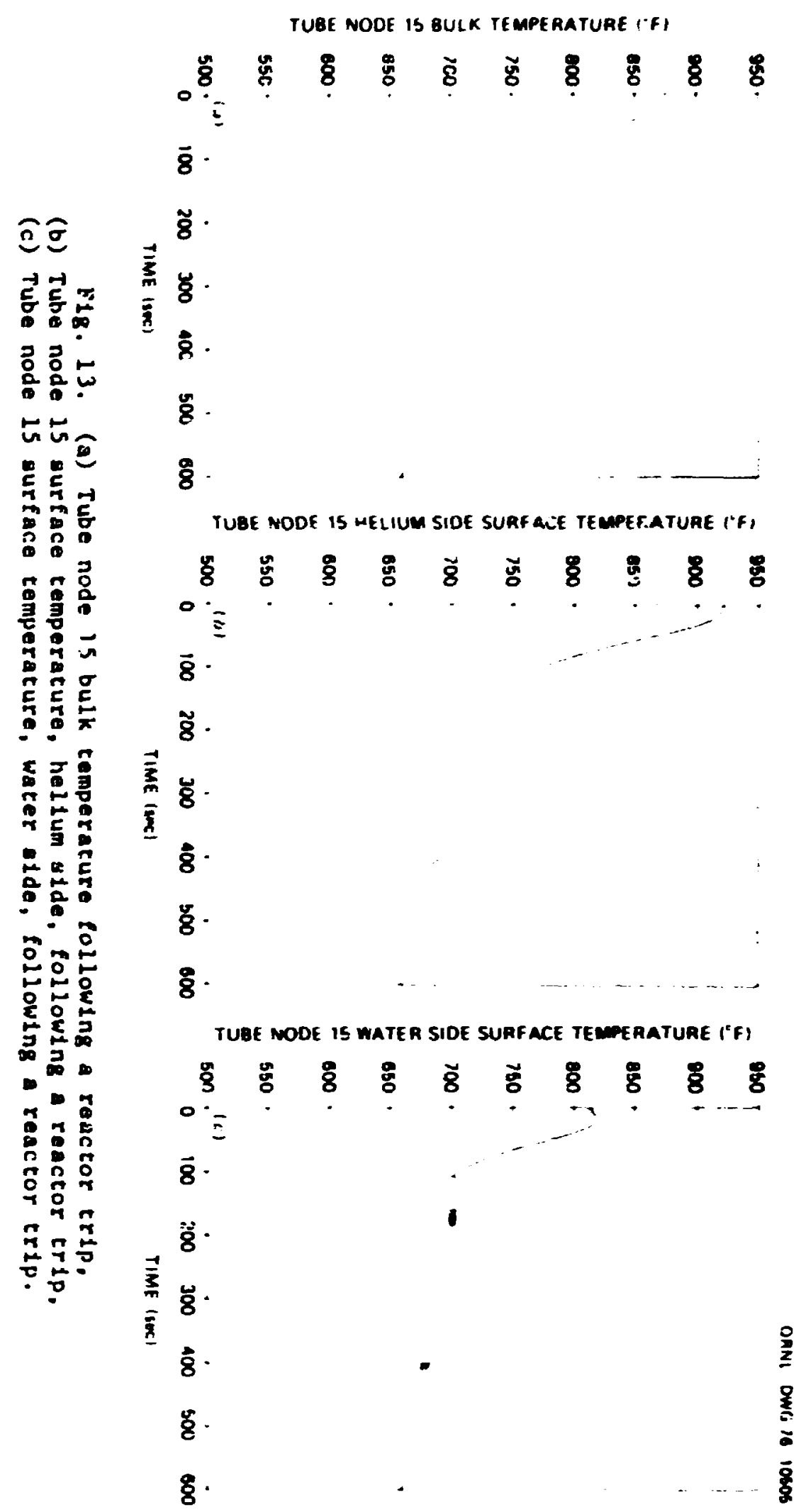



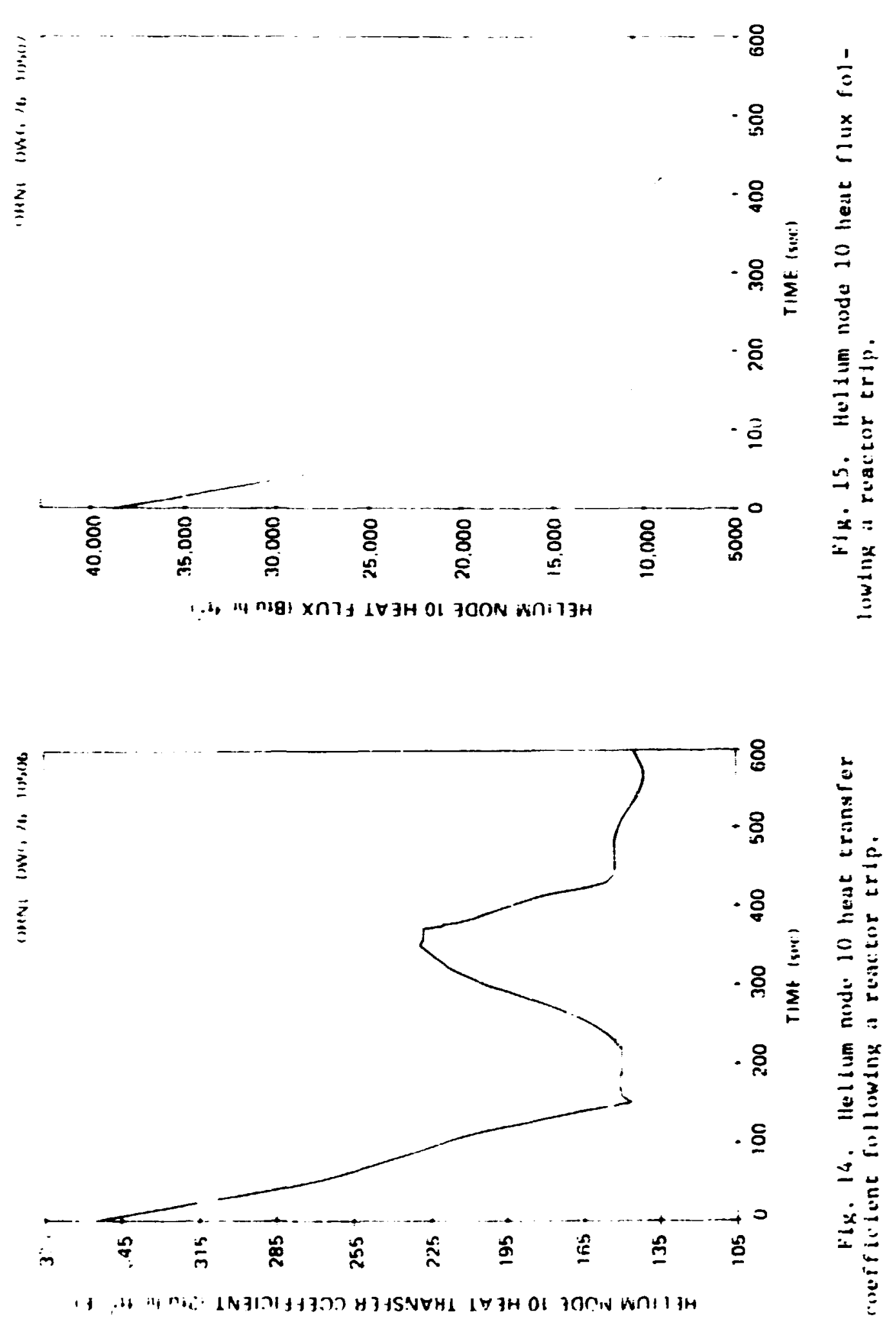

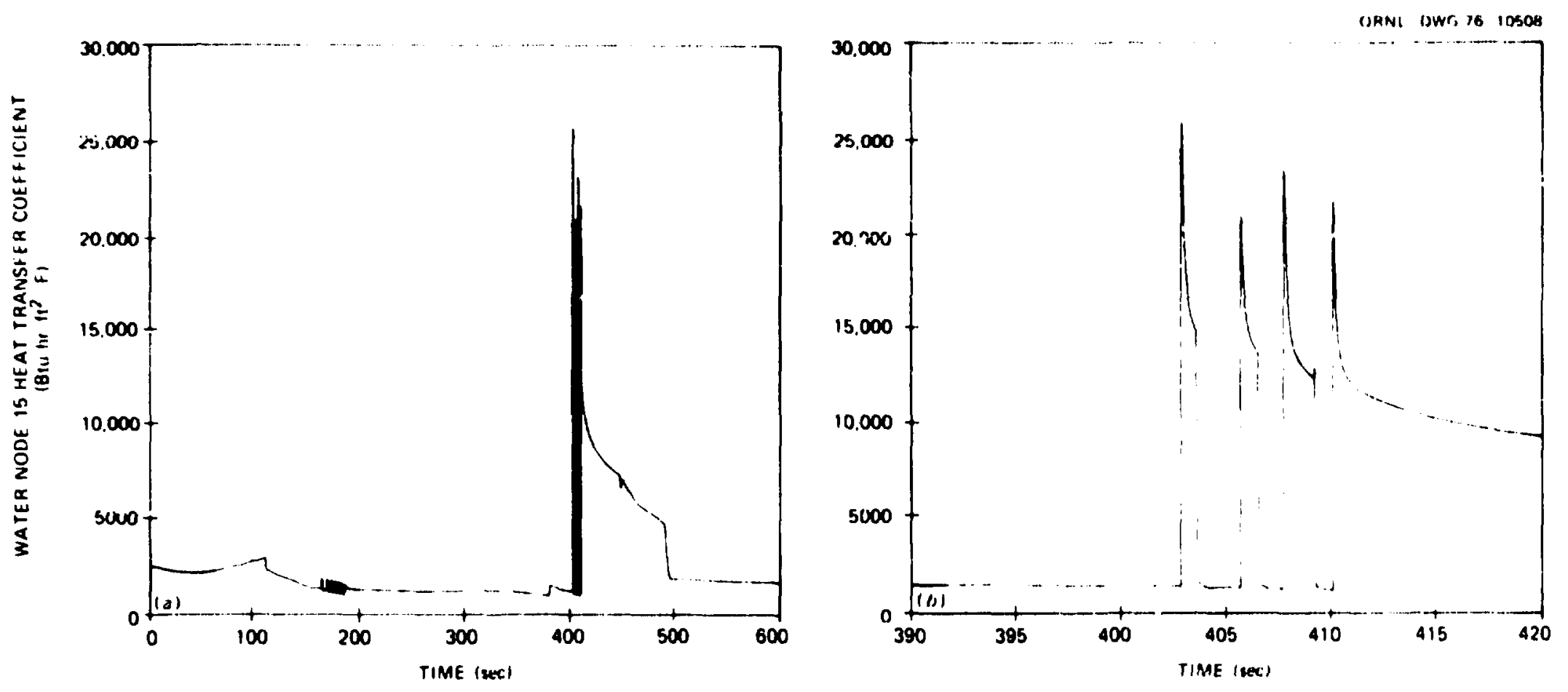

Fig. 16. (a) Water node 15 heat transfer coefficient following a reactor trip, (b) Water node 15 heat transfer coefficlent following a reactor trip. 
OANL DWG $76 \quad 105199$
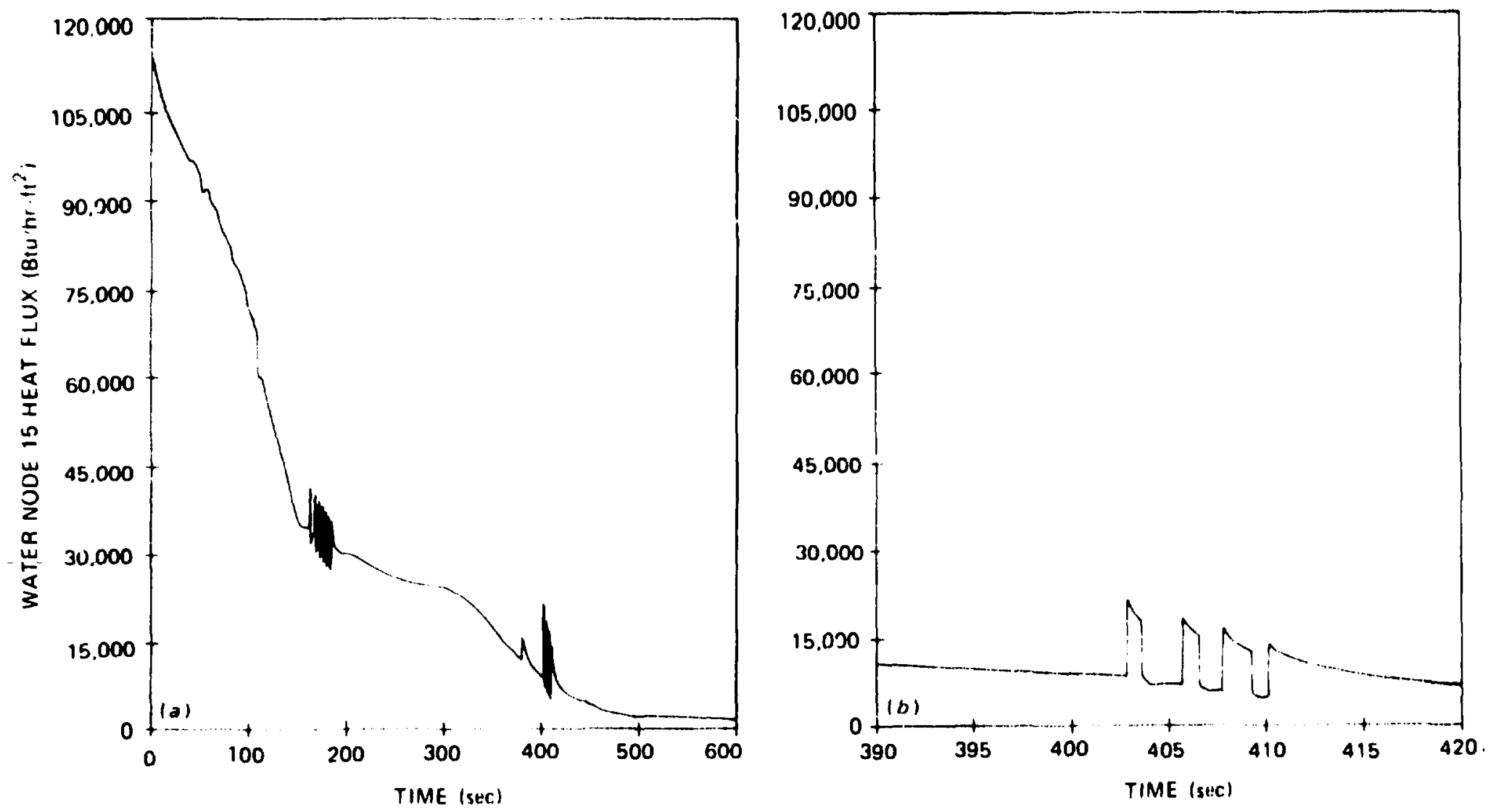

Flg. 17. (a) Water node 15 heat flux following a reactor trip, (b) Water node 15 heat flux following a reactor trip. 

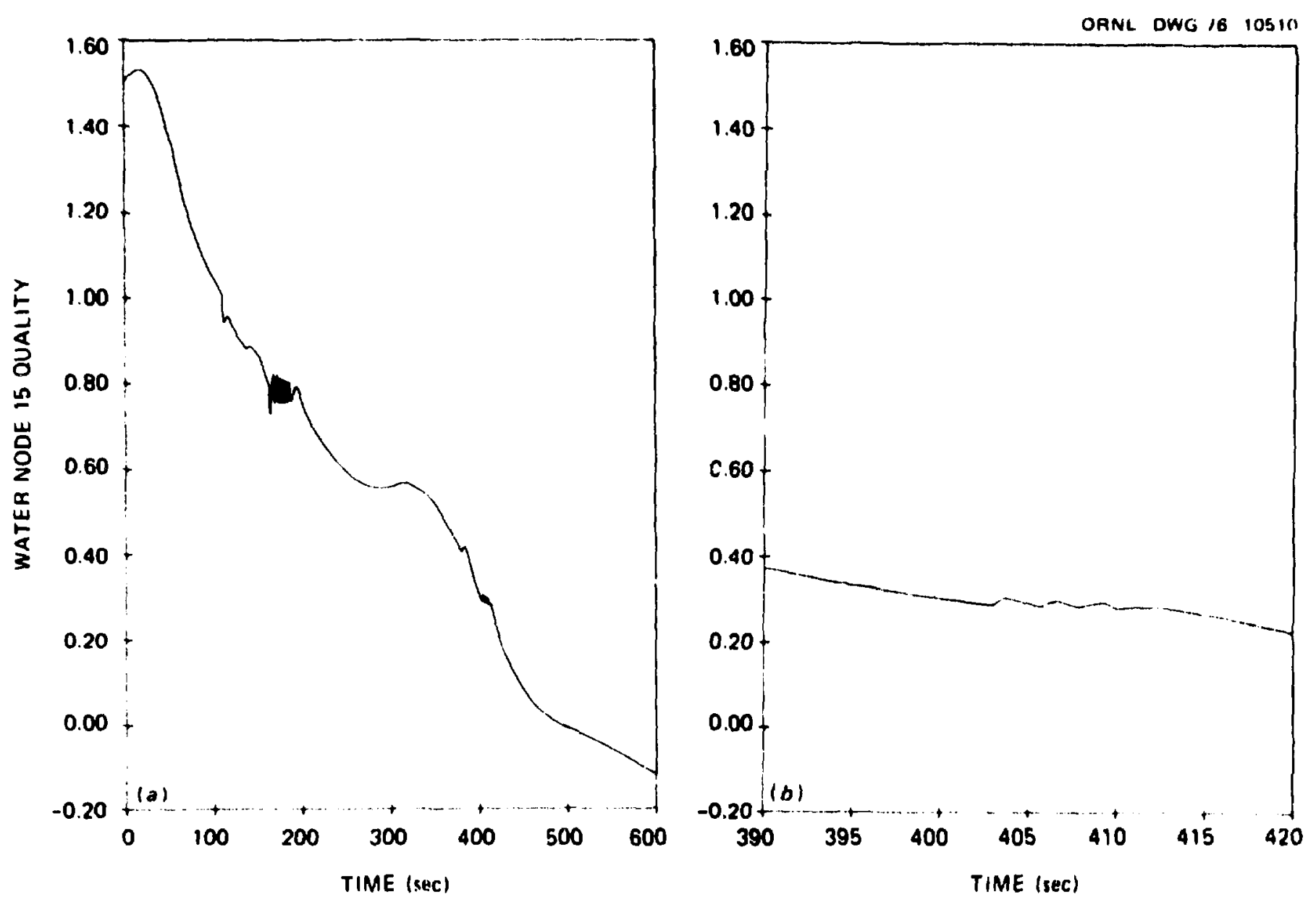

Fig. 18. (a) Water node 15 quality following a reactor trip, (b) Water node 15 quality following a reactor trip. 
result of oscillations in the heat transfer coefficient in the upstream node between film boiling and nucleate boiling.

PLANS FOR FLTLRE USE

The future uses of BLAST include analyzing other transients resulting from normal plant operation and from postulated accident conditions. BLAST is currently being used to model the Fort St. Vrain reheater steam generator module. Results obtained with this model will,first be compared with a linear model developed by the University of Tennessee and then with FSV dynamic test results. BLAST will also be used to analyze the transient behavior of the steam generator during postulated depressurization and partial loss of forced circulation accidents.

BLAST is being used to obtain information concerning pressures and temperatures necessary for stress analyses on the General Atomic redesigned reheater-steam generator module for the Delmarva plant. Also, BLAST has been incorporated into ORTAP, a system simulation code for the HTGR. A comparison of the modeling techniques used in BLAST with those used by General Atomic for the steam generator model in TAP $^{21}$ will be made once the TAP code is made operational at ORNL.

\section{REFERENCES}

1. G. M. Schultz, "Large HTGR Steam Generator Design Verification and Support Programs - Heat Transfer, Fluid Flow, and Stability," GulfGA-A12809. Volume II (GA-LTR-5), (December 15, 1973).

2. F. Kreith, Principles of Heat Transfer, Internationa1 Text Book Co., Scranton, Pennsylvania, 1966. 
3. J. R. S. Thom, et al., "Boiling in Subcooled Water During Flow Up Heated Tubes or Annuli," Proc. Irst. Mech. Eng. 180 (Part 3C), Pp. 226-46 (1966).

4. J. B. McDonough, H. Milich, and E. C. King, Partial Film Boiling with Water at 2000 psig in a Round Vertical Tube, MSA Research Corporation, Technical Report 62 (1958) (NP-6976).

5. R. S. Dougall and H. M. Rosenhow, Film Bofling on the Inside of Vertical Tubes with Upward Flow of the Fluid at Low-Qualities, MITTR-9079-26 (1963).

6. D. C. Groenveld, An Investigation of Heat Transfer in the Liquid Deficient Regine, AECL-3281 (Rev.).

7. C. D. Morgan, "A study of Film Boiling from Vertical Surfaces," Ph.D. Dissertation, Lehigh University, (1965).

8. L. S. Tong, DNB Prediction for an Axiaiiy Non-Uniform Heat Flux Distribution, WCAP-5584, Rev. 1 (1966).

9. E. Jansen, S. Lovy, jnd J. A. Kervinen, "Investigation of Burnoutirternally Heated Annulus Cooled by Water at 600 to 1450 psi," ASME No. $63-W A-149$ (1963).

10. J. S. Gellerstedt, et al., "Correlation of Critical Heat Flux in a Bundle Cooled by Pressurized Water:" pp. 63-71 in Two Phase Flow and Heat Transfer in Rod Bundles Sympos:um, Symposium presented at the Winter Annual Mceting of the ASME, Los Angeles, Calffornia (November 1969).

11. P. G. Barnett, A Correlation of Burnout Data for Uniformly Heated Annuli and Its Use for Predicting Burnout in Uniformly Heated Rod Bundles, AEEW-R463 (1966). 
12. Crane Technical Paper 410, Flow of Fluids Through Valves, Fitcings and Pize, Crane Industrial Products Group, Chicago, Illinois.

13. R. C. Martinelli and D. B. Nelson, "Prediction of Pressure Drop During Forced-Circulation Boiling of hater," Trans. ASME, $\underline{781}$ (1948), pp. 695-702.

14. J. R. S. Thom, "Prediction of Pressure Drop During Forced-Circulation Boiling of Water," Int. J. Heat Mass Transfer, Vol. 7, Pergamon Press (1964), pp. 709-24.

15. R. A. Hedrick, "An Implicit Solution Technique for Analysis of :ossof-Cooiant Accidents," MS Thesis, Lniversity of Tennessee, (1974).

16. H. Petersen, Risö Report No. 224, September 1970.

17. J. R. Tallackson, "The Thermal Transport Properties of Helium, Helium-Air Mixtures, Hater and Tubing Steel tsed in the CACHE Program to Compute HTGR Auxillary Heat Exchanger Performance," ORNL/TM-4931.

18. Thermodynamic and Transport Properties of Steam, ASME, 1967.

19. R. C. Foltz, WPROP - A Program to Calculate Water Properties, Babcuck and Wilcox, NPGD, September 1973.

20. T. A. Porsching, J. H. Murphy, J. A. Redfield, and V. C. Davis, FlASH-4: A Fully Implicit FORTRAN-IV Program foi the Digital Simulation of Transients in a Reactor Plant, WAPD-TM-840, March 1969.

21. "Transient Analysis Program," Culf General Atomic Report GiND-7248 (Revision), 1973.

22. An Analysis of HTGR Core Cooling Capability, Gulf Gu neral Atomic, Gulf-GA-A12504 (GA-LTR-1), 193. 


\section{APPEXDIX A: INPUT DESCRIPTIOA}

The input data required by the code is described below. Subroutines which wust be supplied by the user are described in Appendix B. The input will be wore easily understood if studied in conjunction with the input card listing and initial printout of the sample problem in Aptendix $B$ and with the nodal description for this sample problem show in Figure 2. In determining a nodal arrangement such as in Figure 2, the user should place nodal boundartes where the tube material or diameter changes. Also, dividing a length of tube of a given material and diamecer into more than one node provides finer calculational detail and therefore more accurate results.

The first entry on each data card is a card series number. The data cards must be ordered numerically according to this series number. The series number is in format 110 , and the remaining entries are in 10 column fields.

CARD CARD

SERIES FORMAT

$10 \mathrm{NN} \quad \mathrm{I} 10,7 \mathrm{D} 10.2$

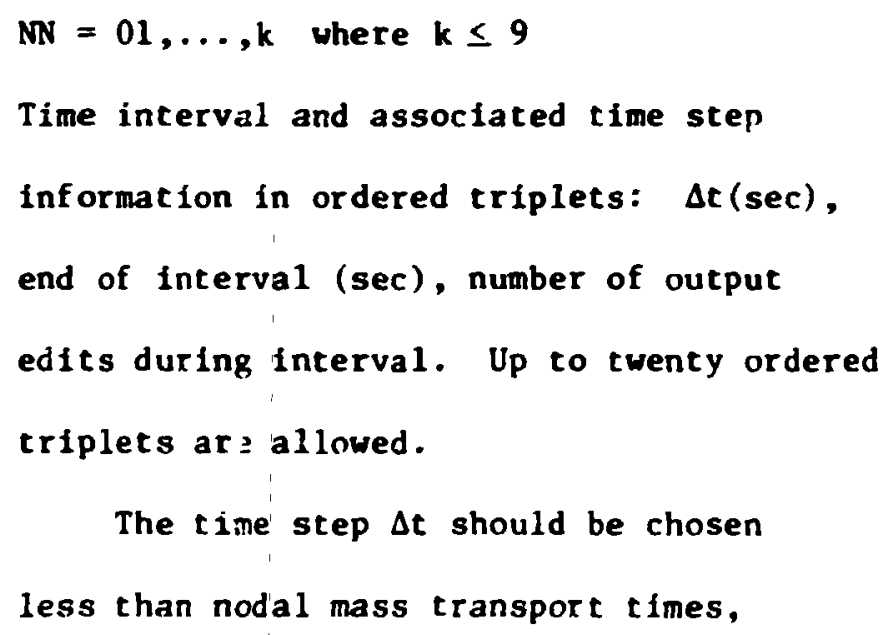


\begin{tabular}{cc} 
CARD & CARD \\
SERIES & FORMT \\
\hline
\end{tabular}

25NN

$M_{i} / W_{1}$. The last card in series loin should be blank in colurens 71-80.

Optional series. See p. 49.

7ONN

$110,4010.2,3110$

NI $=2 N_{v}-1$ where $N_{v} \equiv$ water node number

and $\left(1 \leq N_{w} \leq 20\right)$.

Colums 11-20: Water node $N_{w}$ pressure

guess (psta) for steady state search.

Colums 21-30: Water node $N_{w}$ enchalpy

guess (Btu/1bm) for steady state search.

Columins 31-40: Water node $\mathrm{N}_{\mathrm{w}}$ flow area $\left(f t^{2}\right)$

Colums 41-50: Tube length ( $f t$ ) associated

with water node $N_{w}$.

Columns 5i-60: Outlet posttion $(1=$ top,

0 = bottom) rie: If node is hortzontal,

Input 0 in column 60 and column 70.

Normally the code uses the helght (ft) of

the assoctated helium node for the $\Delta z$

factor in the statio head term in the

water side momentum equation. However,

the user can spacify the value of $\Delta z$ by

inputing, in integer form, $1000 \star \Delta z$ in

columns $61-70$. 
Colurs 71-80: Number of helium node

$\left(A_{h}\right)$ which can transfer heat to this vater node.

70KK 2I10, D10.2, $2110 \quad \mathrm{KK}=2 \star_{w}$; Continuation of information on card TOWN for water node $N_{w}$.

Coluans 11-20: Tube type (Specify 1,2,

or 3)

= 1 for carbon steel (SA-210-A1)

$=2$ f.rr Incoloy 800

$=3$ for Croloy (SA-213-T22)

Colums 21-30: Number of tubes which transfer heat with the helium node referred to in columns $71-80$ of previous card. Columns 31-40: Upstream node number (= 201 for first reheater node) (= 230 for first economizer node.)

Columns 41-50: Downstream node number. (= 215 for last reheater node.) Use $216,217, \ldots$ for multiple reheater exits.

( 251 for last superheater node.) Use $252,253, \ldots$ for multipie superheater exits. 


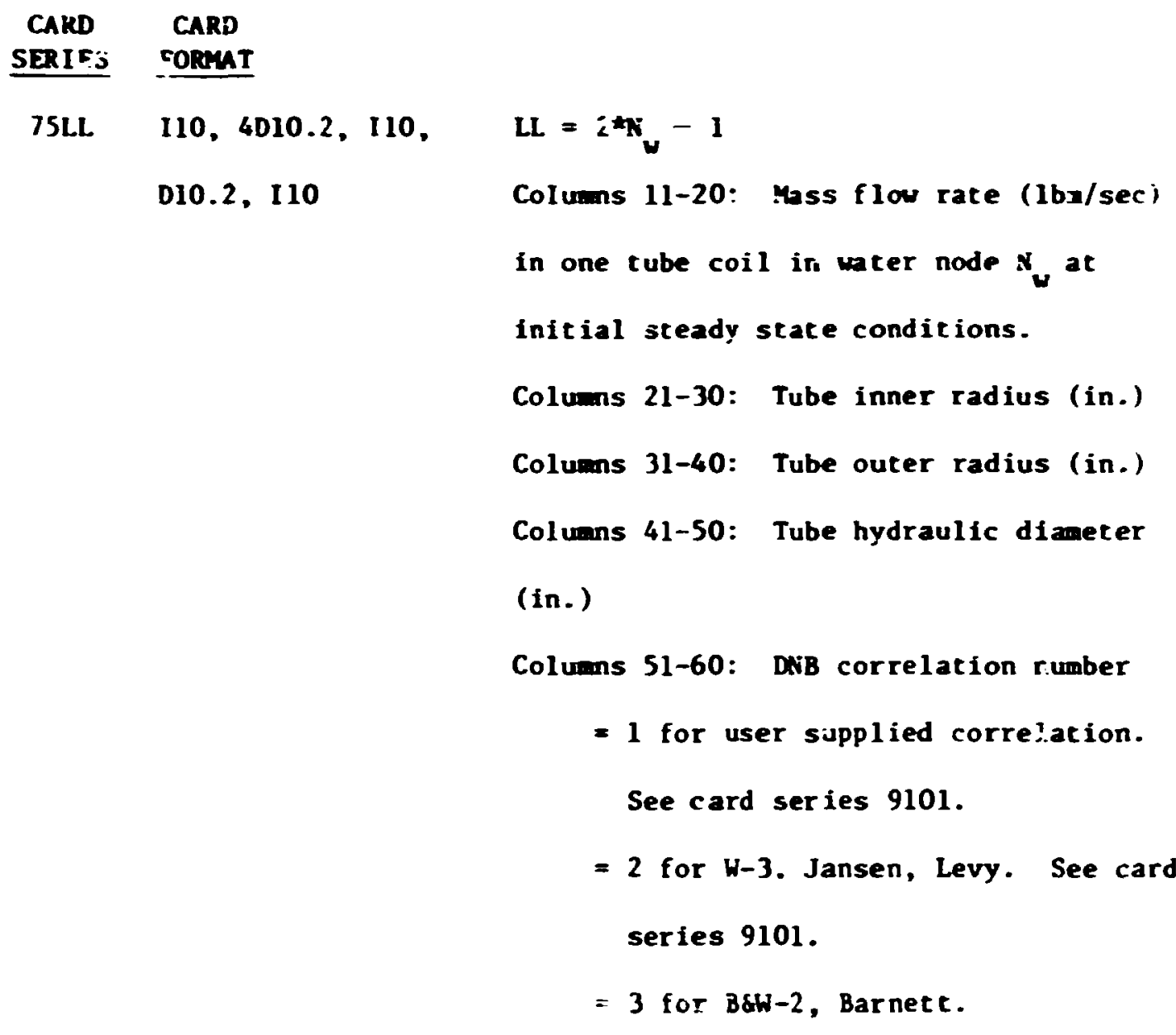

If 1,2 , or 313 shosen, the code will not return to nucleate boiling once DNB has occurred.

$=4$ for user suppifed correlation. See card series 9101.

$=5$ for $W-3$, Jansen, Levy. See card series 9101 .

$=6$ for B\&W-2, Barnett.

If 4,5 , or 6 is chosen, the cocic wijl return to nucleate todlin:; once DNB has occurred. 
Colums 61-70: Minim heat transier

coefficient $\left(B t u / h r-f t^{2}-{ }^{\circ} F\right)$.

Colums 71-80: Fila boiling correlation key.

$$
\begin{aligned}
& \text { (= } 0 \text { for Dougall-Rosenhou) } \\
& \text { (= } 1 \text { for Groeneveld) }
\end{aligned}
$$

7514 $110,3010.2$

wat $=2 W_{w}$; Concinuation oz information on card 75LL for node "N.

Colums 11-20: Constant friction factor for node $\mathrm{N}_{w}$. This friction factor is added to that calculated from the Fanning friction factor curves to determine the friction losses.

Columns 21-30: $\varepsilon / D$ (Roughness to diameter ratio for tube; $D=$ inner didmeter) Columns 31-40: Relative curvature of tubes associated with water node $N_{w}$. (Input 0.0 for straight tubes).

80NN $110,5 D 10.2,2110$ $N N=2 \star N_{h}-1$ where $N_{h} \equiv$ hellum node number and $\left(1 \leq N_{h} \leq 20\right)$. Columns :1-20: Helium node $N_{h}$ pressure guess (psia) for steady state search. 
Coluans: 21-30: Helium node $x_{h}$ enthalpy

guess (Btu/lba) for steady state search.

Coluans 31-40: Helium node $v_{h}$ flow area $\left(f t^{2}\right)$.

Columns 41-50: Helium node $\mathrm{N}_{h}$ flow length (ft).

Columns 51-60: Height of nodal voiume ( $t$ ).

Columns 61-70: Inlet position (l=top,

$0=$ bot $\operatorname{tom}$ ) .

Columns 71-80: Oijier position (1=top, $0=$ bot $\operatorname{tom}$ ).

Note: Input 0 in column 70 and column 80 if node is horizontal.

80KK I10, D10.2, 2I 10

KK $=2 \star_{h}$; Continuation of information on card 80NN for node $\mathrm{N}_{h}$.

Columns 11-20: Nodal volume ( $\mathrm{ft}^{3}$ ).

Columns 21-30: Jpstream node number. ( $=201$ for first reheater node)

(= 215 for first turinel node) $(=230$ for first superheater node)

Columns 31-40: Downstream noje number. i= 215 for last reheater node) Use $216,217, \ldots$, for multiple reheater exits. 


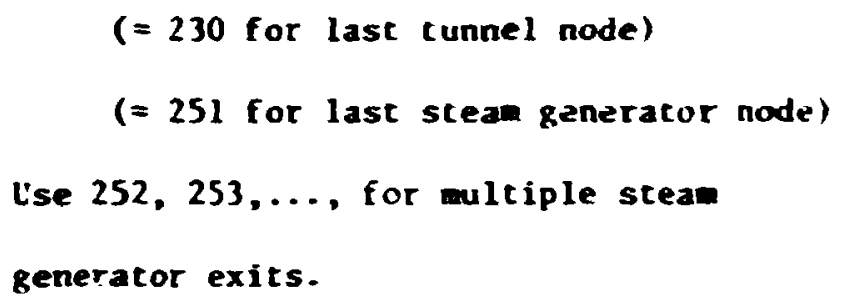

85LL I10, 4D10.2, 2110 ,

$\mathbf{L}=2 * \mathbf{K}_{h}-1$

D10.2

Colwans 11-20: Mass flow rate ( $1 \mathrm{bm} / \mathrm{sec})$

in helium node $N_{h}$ at initial steady state conditions.

Columns 21-30: Average tube OD ( $\left.1 \mathbf{:}^{\circ}\right)$ in helium node $\mathrm{N}_{h}$.

Colums 31-40: Constant friction factor. Columns 41-50: $E / D$ (Roughnes: to diameter ratio: $D=$ outer diameter.). This is used as a key. If $\varepsilon / D \leq 0.0$, only the constant friction factor will be used to compuce friction losses. If $\varepsilon / D>0.0$, the code will calculate a friction factor based on the correlation described in section 6 and add this to the constant friction factor to determine the friction losses. Columns 51-60: Number of inline rcws of tubes in helfum node $\mathrm{N}_{h}$. Columns 61-70: Number of staggered rows of tubes in helium node $N_{h}$. 
$\begin{array}{cc}\text { CARD } & \text { CARD } \\ \text { SERIES FORMT }\end{array}$

Colums 7i-80: Pitch to dianeter ratiotransverse.

6SEM I10, D10.2

$M=2 \star N_{h} ;$ Conitinuation of inforeation on card 85LL for heliu node $N_{h}$.

Colums 11-20: Pitch to dianeter ratiolongl tudinal.

90013110

Colums 11-20: Nubber of first helium node in tunnel.

Columns 21-30: Number of last heliun node in tunsel.

This card series is required if DNB correlation number on card series $75 L L$ is 1 , 2,6 or 5 . Otherwise, this series is omitted.

Columns 11-20: DNB flux (Btu/hr-ft $\mathrm{t}^{2}$ ) for zero qualfty. Used only for INB correlation number $=1$ or 4 .

Columns 21-30: Quality at which DNB occurs. Used only for DNB correlation number $=1$ or 4 .

Columns 31-40: Quality at which DNB flux becomes zero. Used inly for DNB correlation number $=1$ or 4. 
CARD CARD

SERIES FORMT

$9201110,2 \mathrm{D} 10.2$

$18001 \quad 2 \mathrm{I} 10,6 \mathrm{D} 10.2$

$180 \mathrm{NN}$
Colums 41-50: "E factor" in Jansen-Levy correlation. See Reference 9. Used only for DNB correlation number $=2$ or 5.

Colimns 11-20: Allowable temperature change for water before recomputing thermodynamic transport prcperties.

Columns 21-30: Allowable temperature change for helium before recomputing thermodynamic transport properties.

Steam generator (water side) inlet flow rate vs time in one tube.

Columns 11-20: Number of pairs (time, flow rate) describing water side inlet flow rate vs time. Up to 150 pairs may be input.

Columns 21-30: Time (sec).

Columns 31-40: Flow rate $(1 \mathrm{bm} / \mathrm{sec})$.

Columns 41-60: Repeat Columns 21-30.

Columns 61-80: Repeat Columns 31-40.

NOTE: Code interpolates 1inearly between Input values.

NN $=2, \ldots, k$ where $k \leq 42$. Continuation of card $180 \mathrm{CL}$. 


\section{CARD CARD \\ SERIES FORMAT}

$18101 \quad 2110,6010.2$

181NN $110,7 D 10.2$

18201

$2110,6 \mathrm{D} 10.2$

182NN
$110,7010.2$
Steam generator (water side) inlet pressure vs time.

Columns 11-20: Number of pairs, ( $t$ ime, pressure) describing water side inlet pressure vs time.

Coluans 21-30: Time (sec).

Columns 31-40: Pressure (psia).

Columns 41-50: Repeat Columns 21-30.

Columens 61-80: Repeat Columns 31-40.

$\mathrm{MN}=2, \ldots, \mathrm{k}$ where $\mathrm{k} \leq 42$. Continuation of card 18101.

Steam generator (water side) inlet enthalpy vs time.

Columns 11-20: Number of pafrs (time, enthalpy).

Columns 21-30: Tíme (sec).

Columns 31-40: Enthalpy (Btu/1bm).

Columns 41-60: Repeat Columns 21-30.

Columns 61-80: Repeat Columns 31-40.

$N N=2, \ldots, k$ where $k \leq 42$. Continuation of card 18201. 
CARD CARD

SERIES FORMAT

$18501 \quad 2 \mathrm{I} 10,6 \mathrm{D} 10.2$

$185 \mathrm{NN} \quad \mathrm{I} 10,7 \mathrm{D} 10.2$

$186012110,6 D 10.2$

$186 \mathrm{NN}$
$\mathrm{NN}=2, \ldots$

of card 18501.

Reheater (hellur side) inlet pressure vs

time.

Columns 11-20: Number of pairs (rime,

pressure) describing helfum inlet pressure

vs time.

Columns 21-30: Time (sec).

Columns 31-40: Pressure (psia).

Columns 41-60: Repeat Columns 21-30.

Columns 61-80: Repeat Columns 31-40.

NN $=2, \ldots, k$ where $k \leq 6$. Continuation

of card 18601. 
CARD CARD

SERIES FORMAT

$187012 \mathrm{I10}, 6 \mathrm{Dl} 0.2$

$187 \mathrm{NN} \quad \mathrm{I} 10,7 \mathrm{D} 10.2$
Reheater (helium side) inlet enthalpy vs time.

Columns 11-20: Number ố pairs (time, enthalpy) describing helium inlet enthalpy vs time.

Columns 21-30: Time (sec).

Columns 31-40: Enthalpy (Btu/1ba).

Columns 41-60: Repeai Columns 21-30.

Columns 61-80: Repeat Columns 3:-40.

$\mathrm{NN}=2, \ldots, \mathrm{k}$ where $\mathrm{k} \leq 42$. Continuation

of card 18701 .

In addition to the above required input, data cards may be supplied which request plots. Two data cards with successive carri series numbers are required for each plot. Card series numbers for the plot request cards begin with 2501 , cannot exceed 2580 and must be consecutive. They must also be in numerical order with the required input cards, $1 . e .$, they must follow the last 10NN card.

The two cards required for each plot are:

First Card: $\quad(2110,3010.2,110,010.2)$

Columns 1-10: Card series number. 


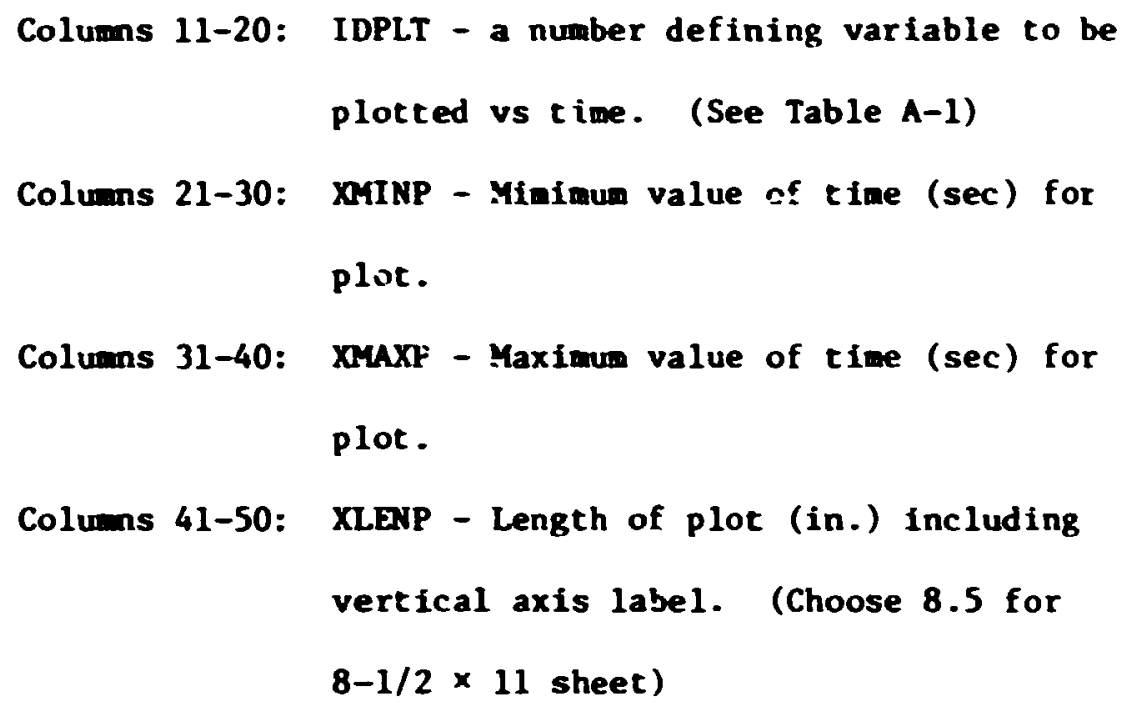

Colums 51-60: Not used.

Colums 61-70: YMINP - Minimu value of dependent variable for plot.

Second Card $\quad(110,2 \mathrm{~J} 10.2,2 \mathrm{I10})$

Columns 1-10: Value of series number on first card (for this plot) plus 1.

Colums 11-20: YMAXP - Maximum value of dependent variable for plot.

Note: If YMINP and YMAXP are both input as 0.0 , the code searches for a maximum and a minimum.

Columns 21-30: YLENP - Height of plot (in.) including horizonta? axis labels. (Choose 11.0 for $8-1 / 2 \times 11$ sheet)

Column 31-40: N1PLT - If plotting $\Delta P$, N1PLT is the first node number for the $\Delta P$. Otherwise N1PLT = 0. 
Columns 41-50 N2PLT - If plotting $\triangle P$, N2PLT is the second note number for the $\triangle P$. Otherwise N2PLT = 0. 
Table A-1. Values of IDPIT for card series 25NN

IDPLT

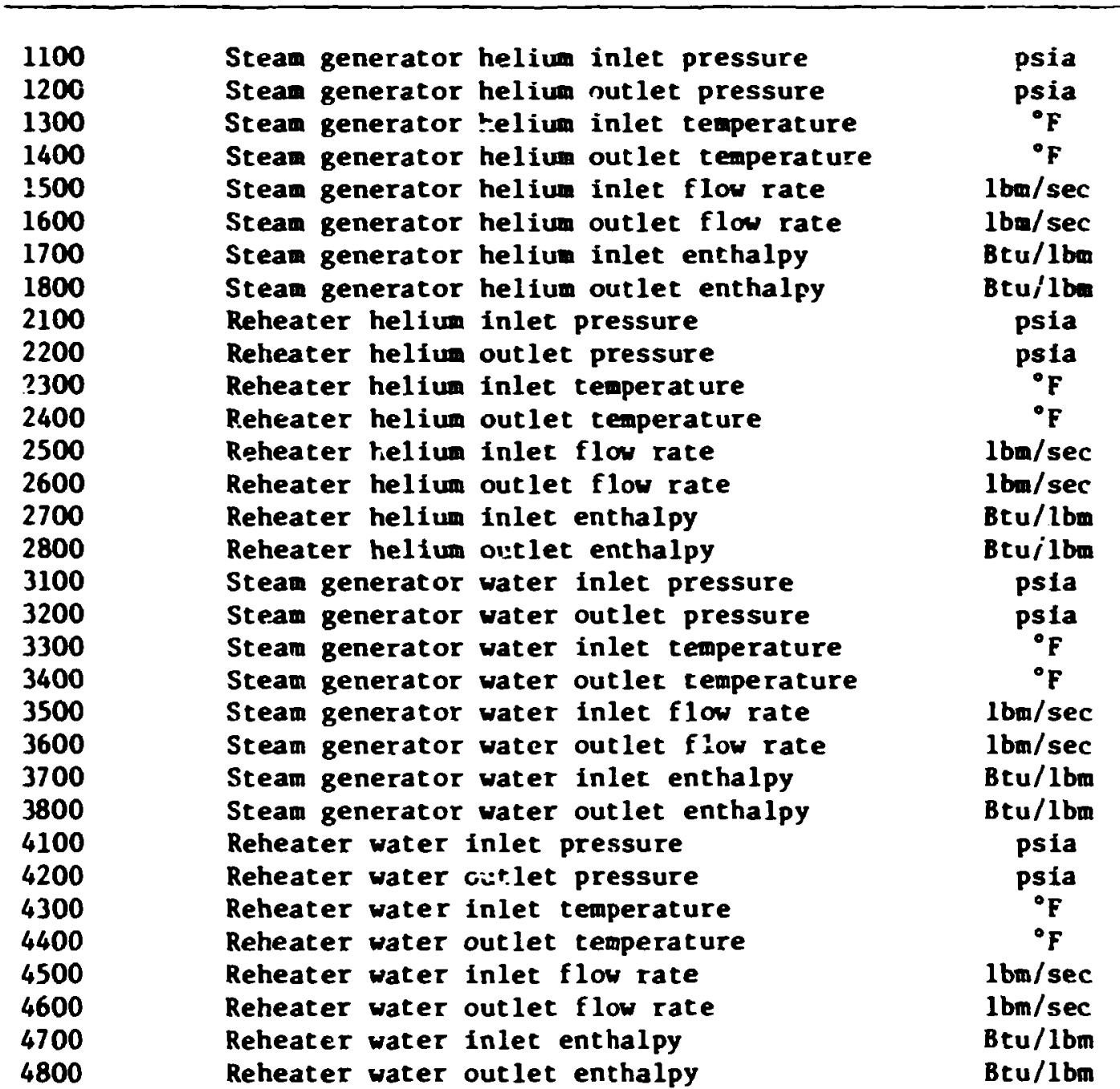


Table A-1. (Cont inued)

IDPLT

NNN $\equiv$ NOUE NUMBER

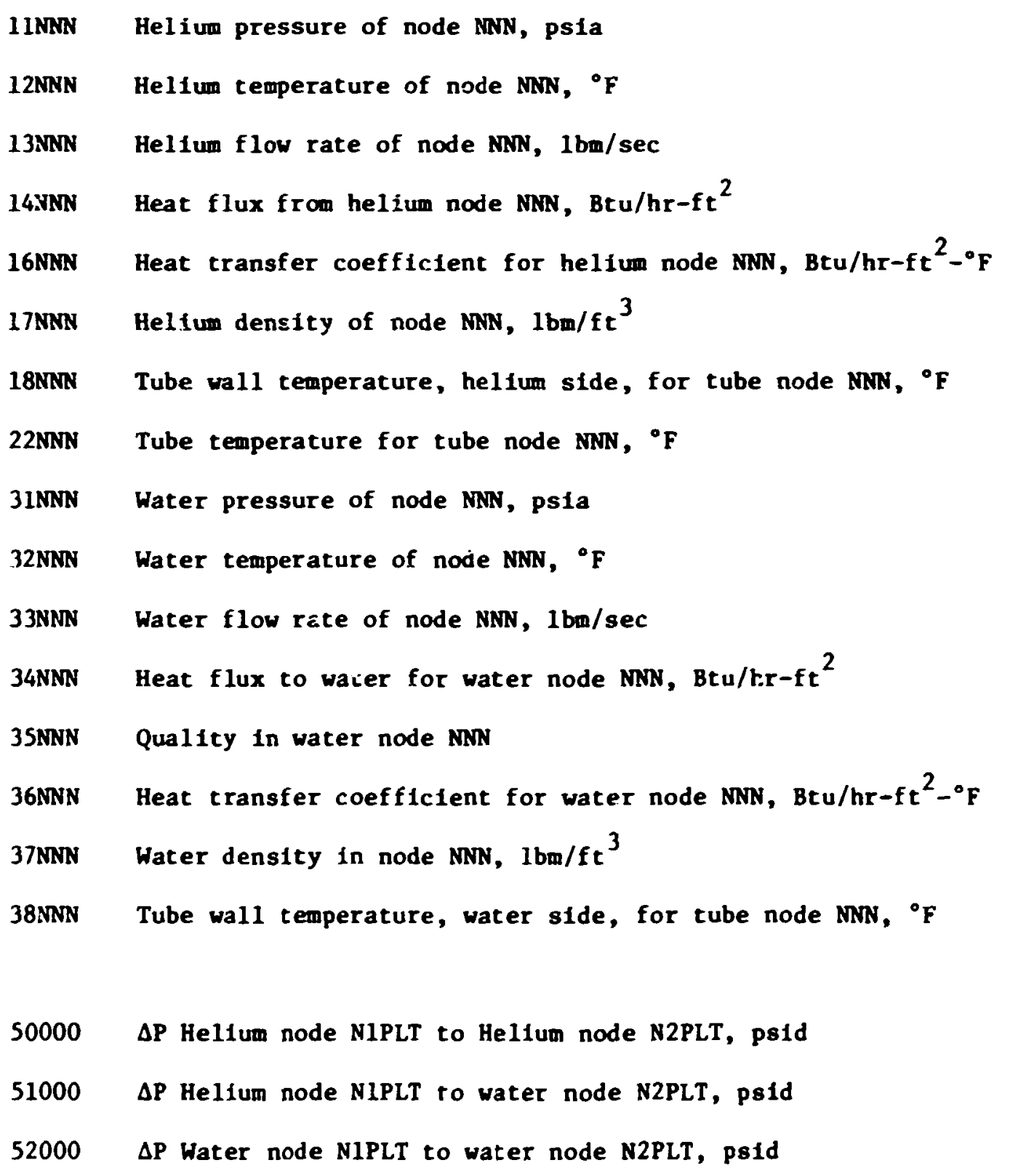


APPENDIX B

BLAST requires the user to supply three subroutires. They are SUBROUTINE POH: Through this subroutine the user supflies the fractional change, FH, in the helium pressure at the outlet of the last helium node as a function of time. This pressure is used only to obtain a value for the $\Delta P$ term in the momentum equation (6) for the last helium node. Since BLAST calculates the helium out let pressure for the initial stcady-state conditions, the out let pressure used in the $\Delta P$ term is found from $P=$ $P_{\text {out }}(t=0) \star F H$. The user must supply the values of the fractional change in helfum pressure at the out let of the last helfum node at selected times through the DATA statements. The code then linearly interpolates to determine FH at each time step.

SUBROUTINE POW: This subroutine supplies the fractional change, FREHET, in pressure at the out let of the last reheat stea'n node and the fractional change, FSGEN, in pressure at the outlet of the last main steam node as functions of time. These pressures are used to determine the $\Delta P$ terms in the momentum equation for the last reheater node and the last superheater node respectively. The user must supply values for the fractional change in pressure at the outlet of the last reheat steam node at selected times through the DATA statements. The code then linearly interpolates to find FREHET and FSGEN at each time step.

SLBROUTINE REHETW: This subroutine is used to provide values of reheater inlet flow rate (REWI), inlet enthalpy (HREWI) and inlet pressure (PREWI) on the stean side vs time. The user must input values of inlet flow rate, inlet enthalpy and inlet pressure at selected times through DATA statements. The code then linearly interpolates to determine inlet flow race, enthalpy and pressure at each time step. 
The first output generated by the code is the listing of the input data card images followed by several pages which display this input information in tabular form. Next, results of the steady-state iteraticn are displayed. The "calculated friction factors" listed in this steadystate output are obtained from the user supplied information and pressure drop correlations while the "input friction factor" is the sum of the constant friction factor (input by the user on card series 75MM) plus an adjustment made by the code to force dW/dt (Eqs. 3 and 6) to be exactly zero atter all parameters have achieved steady-state convergence. This adjustment factor should be an order of magnitude or more snaller than the calculated friction factor. At various times, determined by input on card series 10NN, the code prints out information concerning the water side, helium side and tubes in the reheater and steam generator. These tables contain information concerning the nodal pressure, Irass, internal energy, temperature, flow rate (in one tube on the water side, the total flow rate on the helium side) values for each of the terms in the momentum equations ( 3 and 6 ), heat transfer coefficient, heat flux, tybe surface and bulk temperatures, heat $t r a n s f \in r$ mode and the heat flux required to cause a departure from the nucleate boiling mode. The keys used to indisate the heat transfer mode are given below:

1. subcooled forced convection,

2. nucleate bolling,

3. transition boiling,

4. film boiling (Dougall-Rosenhow correlation),

5. film boiling (Groeneveld cortelation),

6. f11m bolling (Morgan correlation), and

7. superheat forced convection. 
For the sample problem, the steady-state printout at $t=0$ indicates that the reheater (tube nodes $1-8$ in Fig. 2) is in the superineat forced convection mode, the three economizer nodes and the first evaporator node are in subcooled forced convection, the second evaporator node is in nucleate boiling, the third is in film boiling, and the superheater is in the superheat forced convection mode. The nodal heat transfer modes given at $t=200 \mathrm{sec}$ indicate that the last evaporator node has returned to nucleate bolling, and the first superheater node contains a two-phase fluid in the film boiling mode. By $t=500 \mathrm{sec}$, the evaporator has flooded, and vet steam is being emitted from the superheater, and by $t=600 \mathrm{sec}$, the superheater has also flooded. 


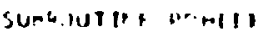

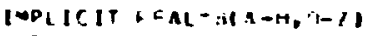

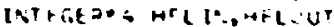

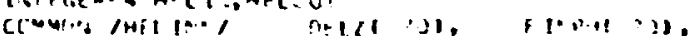

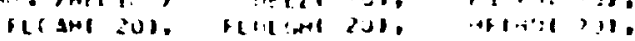

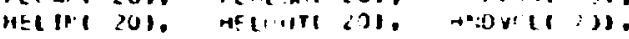

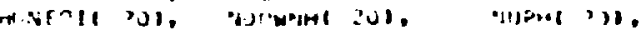

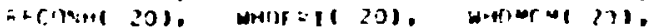

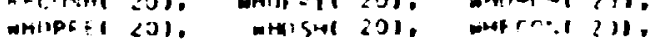

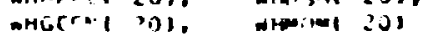

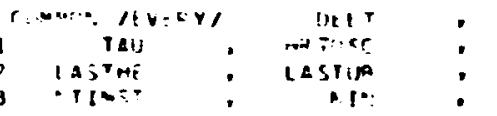

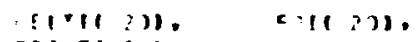

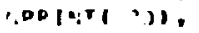

$$
\begin{aligned}
& \because ? ! ?
\end{aligned}
$$

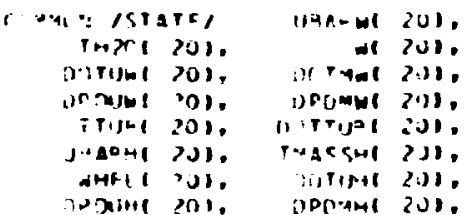

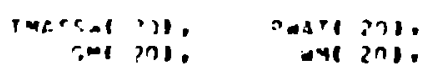

$$
\begin{aligned}
& \text { NTw } 1310
\end{aligned}
$$

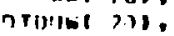

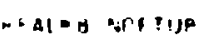

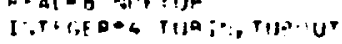

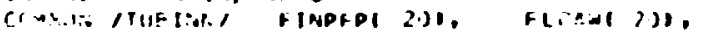

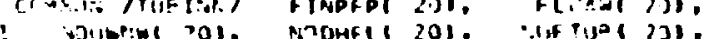

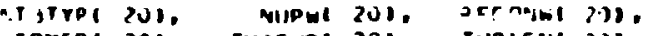

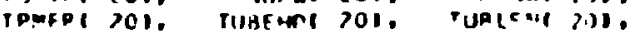

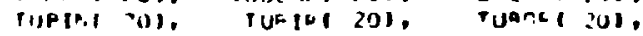

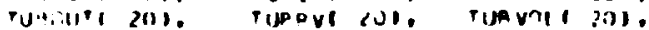

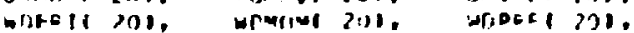

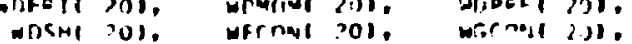

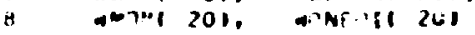

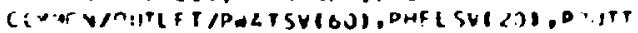

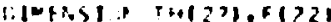

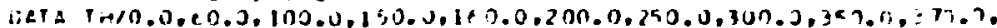

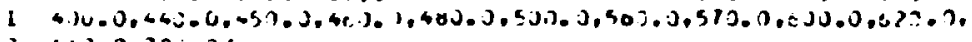

$?+4.0 .700 .0 \%$

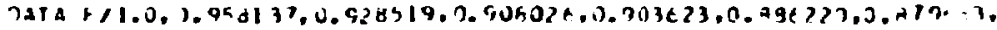

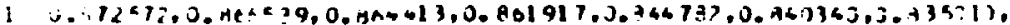

2 i.827u?0.0.611!7?,C. $300949.0 .799000 .0 .189350 .0 .706034 .0 .773 j>50$

3 U. Tn 30121

DATE iH/1/

Sat a nht

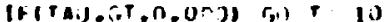

$M+1=N H-1$

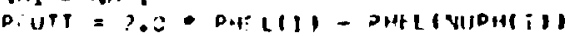

WTIIG.

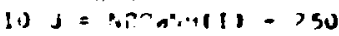

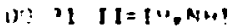

$x=11$

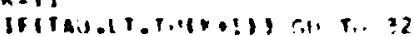

i: Cintiouf

i) $1 \mathrm{in}=\mathrm{n}$

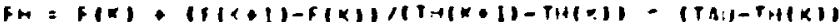

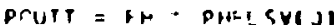

aETUR丨

In)

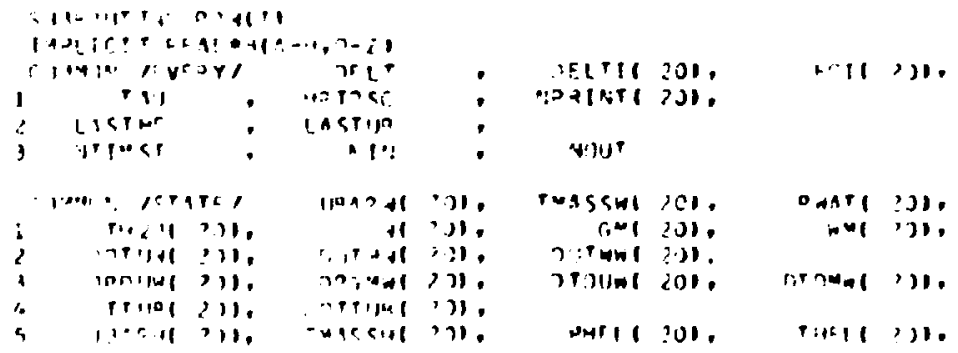




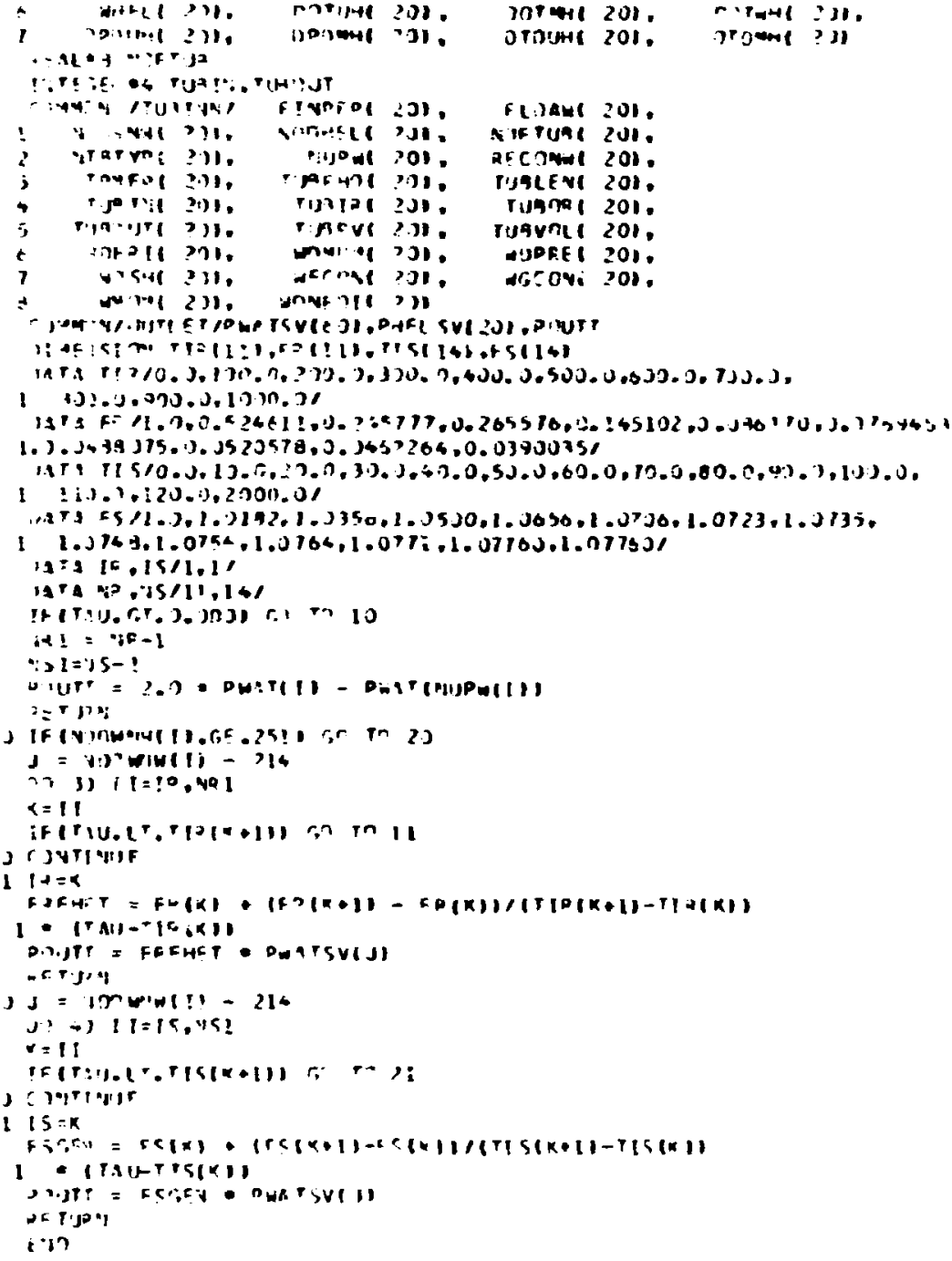

SUBERUTINF UFHETW

C

IPPLICIT DEAL BI A-H, C-LI

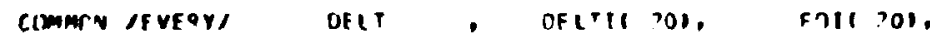

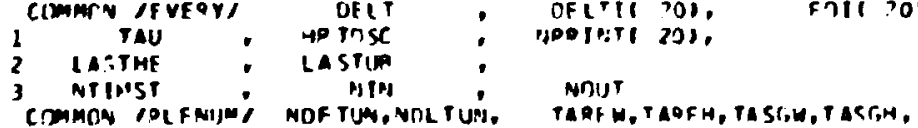

COMMON 100

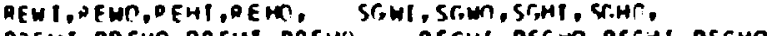

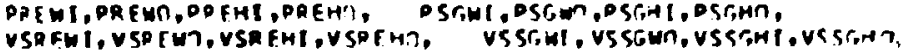

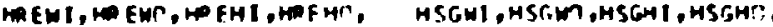

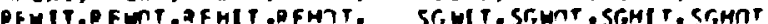

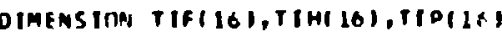

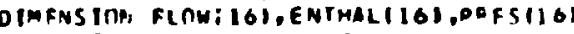

DATA NF,AH, NP/16,16,16/

OATA IF,IH,ID/1,1.1/

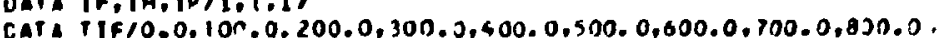

I $900.0,1000.0,1100.0 .1200 .0 .1300 .0 .1400 .0 .1500 .01$

DAT FL NW/ $2225.0,11<6.7,501.3,551.3 .304 .6,173.4 .152 .7 .91 .2 .199 .3$. 
$14,1,70,7,04,7,49.3,35,1,27,0,8,3 /$

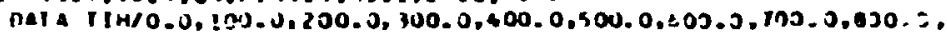

1 Wu.0.1900.0,1100.0.1200.0,1300.0.1400.0.1500.0;

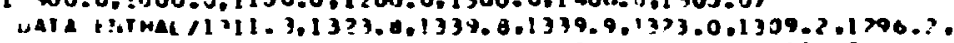

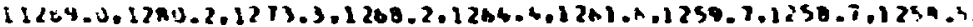

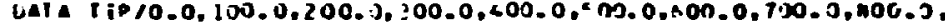

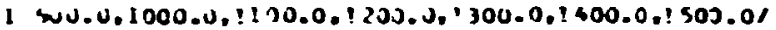

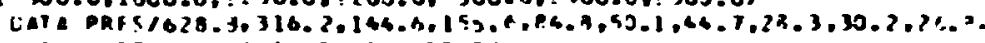

$: \quad 2,0.17 .0,14 .+14.2,13.4,13.51$

p.1 $:=0: 6-1$

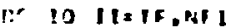

$1=11$

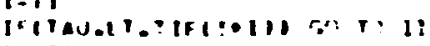

i. $C$ SI Inue

II It = I

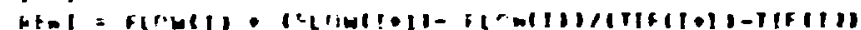

i. Itan- Tiriti)

$\because . r I=:-n-1$

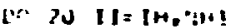

$I=11$

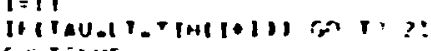

S) Cistinut

21 Int 1

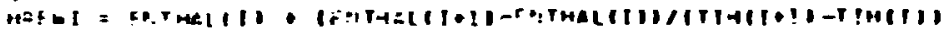

: (1A) - Trilio

P.PI $=P: P-1$

II $30 \quad I I=\left|P_{0}, D P\right|$

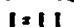

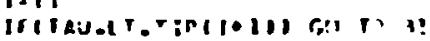

Ju CIRTIIIUF

31 I $b=1$

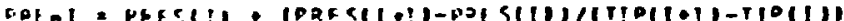

l. I tau - rili II)

$n \mid-1=2 F(1)(t)-219.01$

it Tut

IPet: 
IISTInc igf InDUt oATa capos

\begin{tabular}{|c|c|c|c|c|c|}
\hline 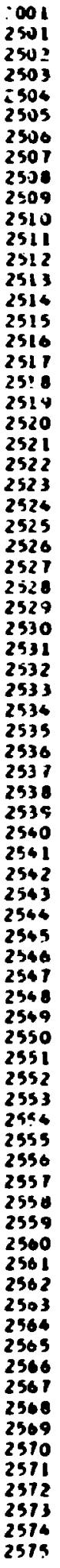 & 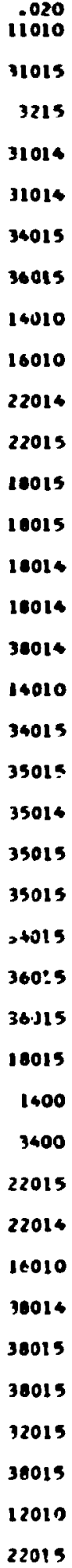 & 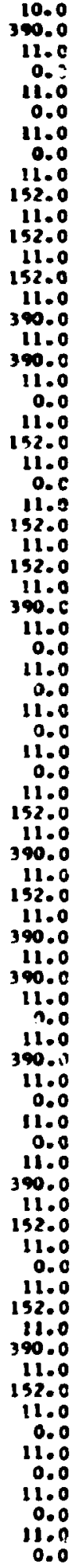 & 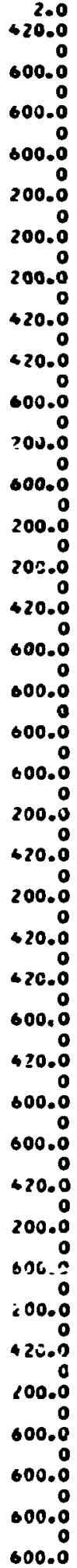 & 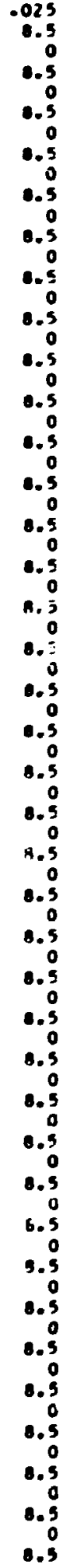 & 610.0 \\
\hline
\end{tabular}




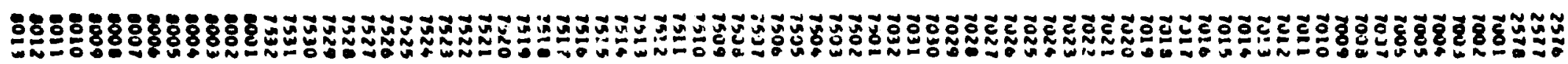

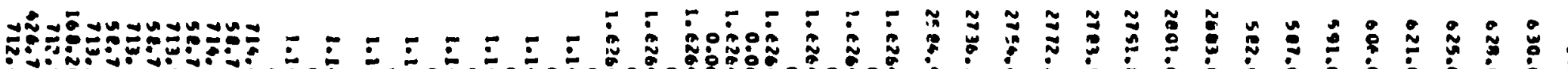

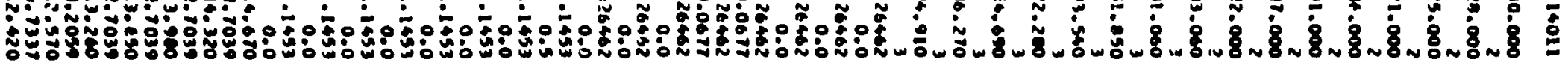

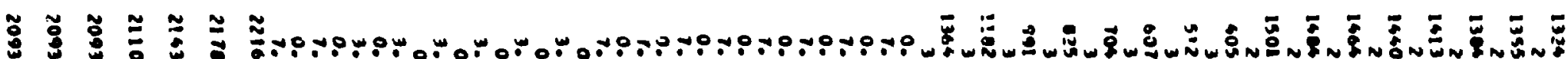
ถั

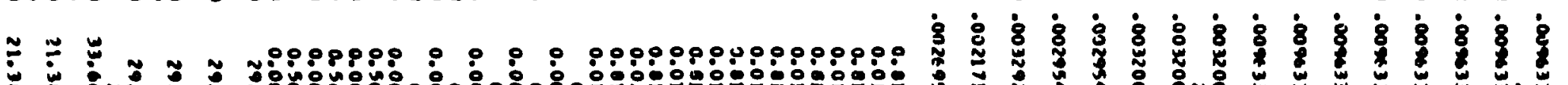

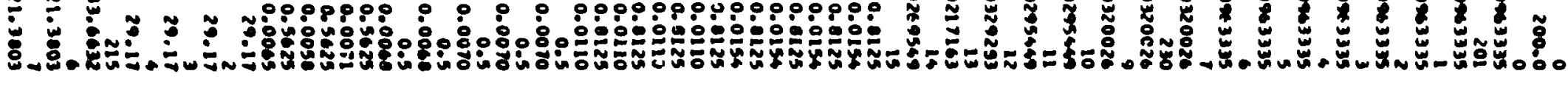

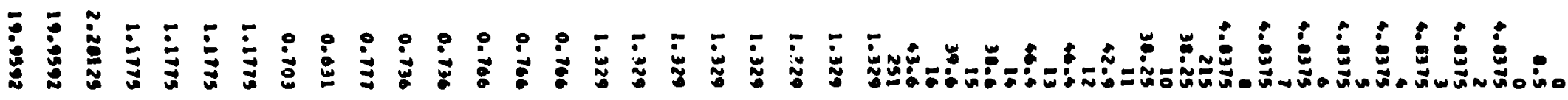
IIIn⿴囗.

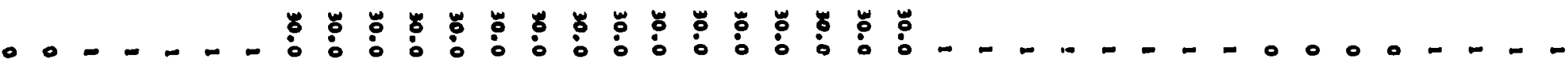




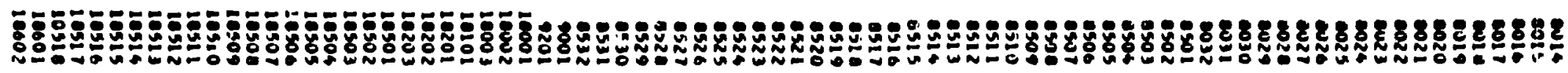

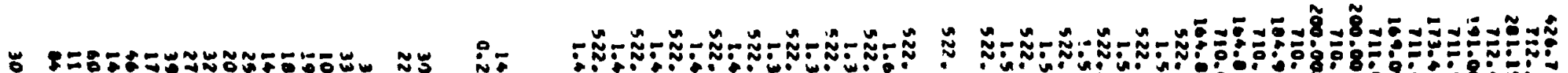

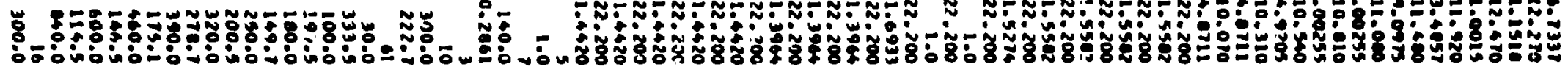

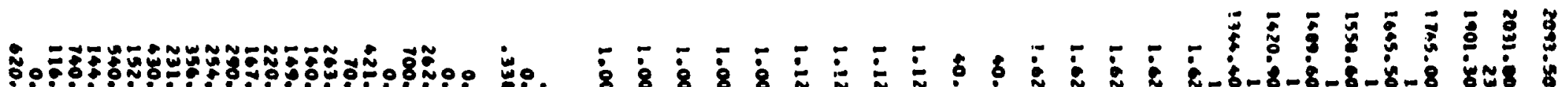

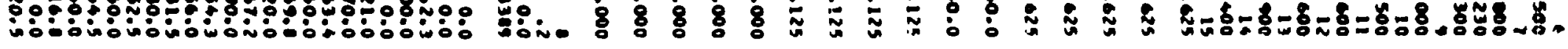

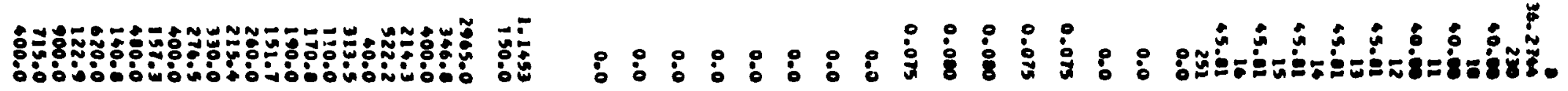

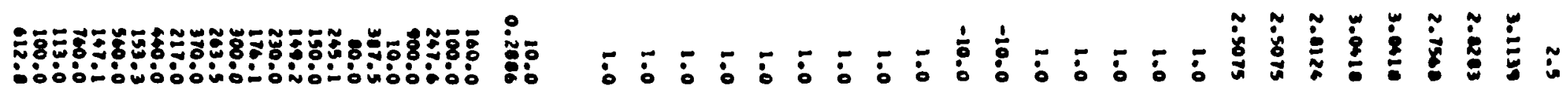

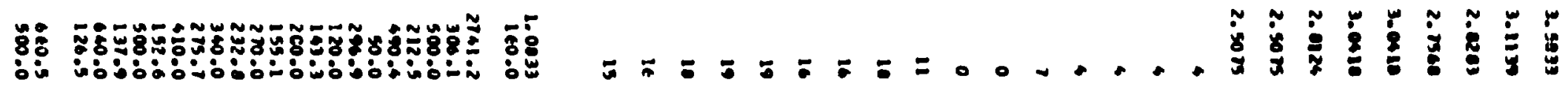

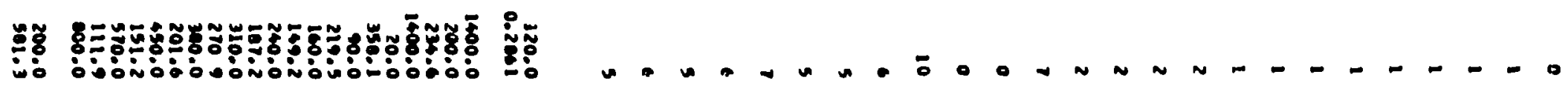

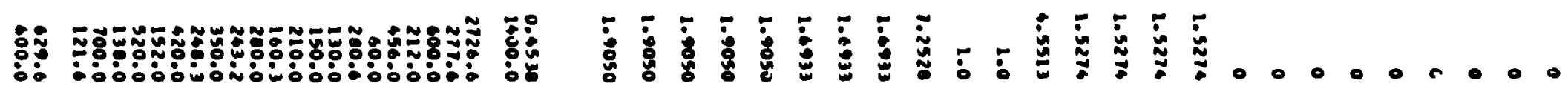




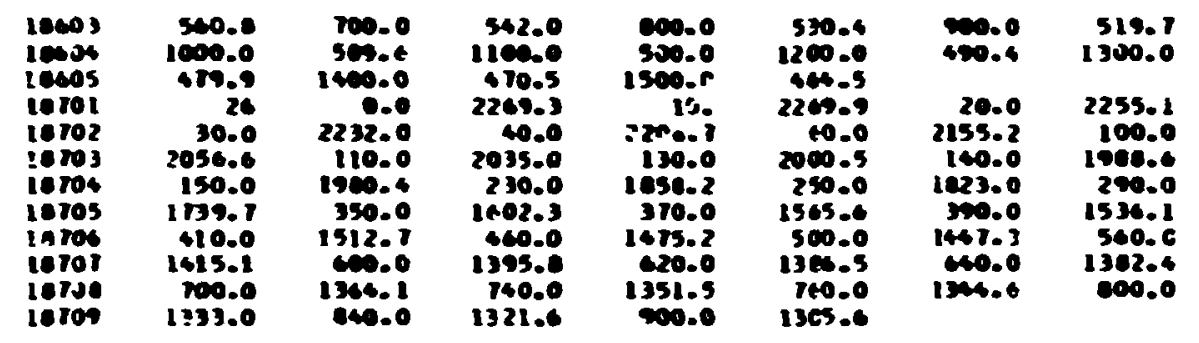




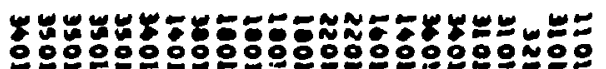

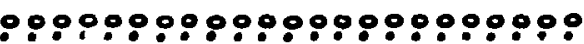
$8000000 \%$

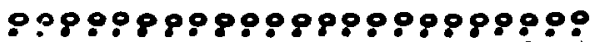

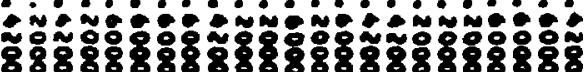

$\sim$

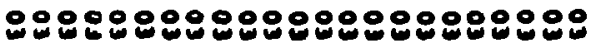

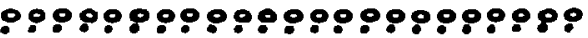

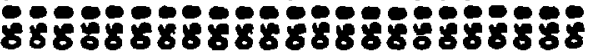
$\mathbf{8 8 8 8 8 8 8 8 8 8 8 8 8 8 8 8 8 8 8 8 8 8 8}$ 9.0009009000909090909009

00000000000000000000000 00000000000000000000000

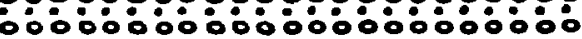

00000000000000000000000 $\because 00: 00: 00: 0: 000: 010000$

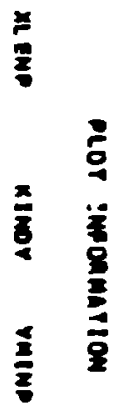

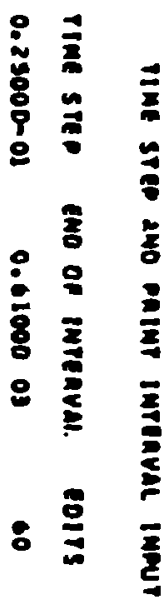

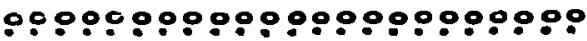

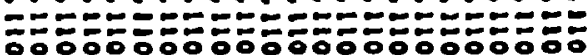

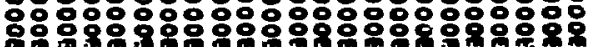

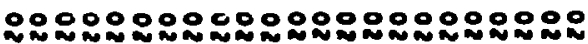

00000000000000000000000

5
5
5
5 
0050000000000000

0050000000000000

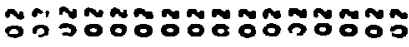

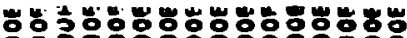

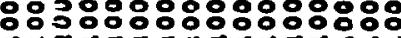

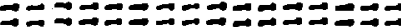

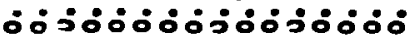

0030000030030000

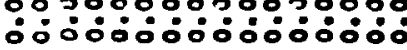

0000000000000000

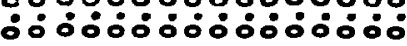
0000000000000000

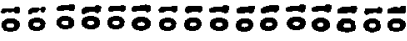

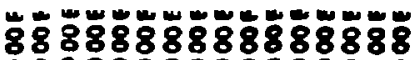

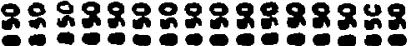

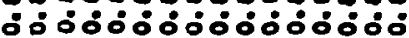

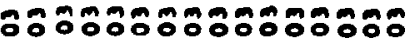

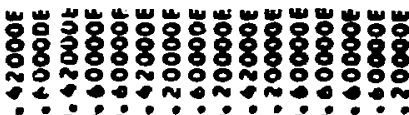

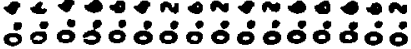

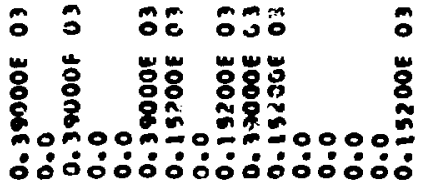

ำ

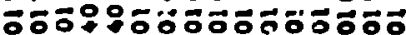

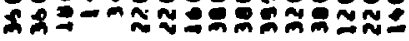

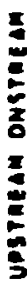

nacos

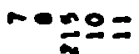

エะะேะ

홍

$e^{-\operatorname{mans}}$<smiles></smiles>

ะェュะ

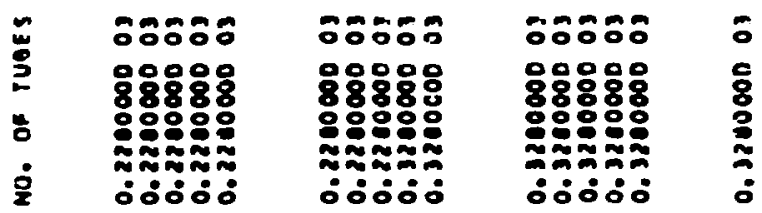

乌ั?

8.

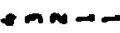

$\cdots+\infty$

ヘேッニー

a

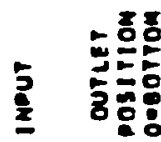

$\infty \sim \infty$

$000-$

$\rightarrow-\infty$

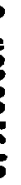

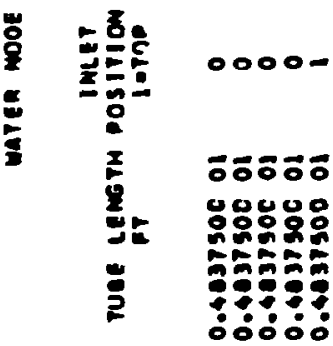

$-\infty-\infty$

00000

-

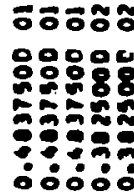

ะัธ์ัธธ์ ะ

붕ํㅇㅇㅛ

89989

:00\%

8
8
8
8
8

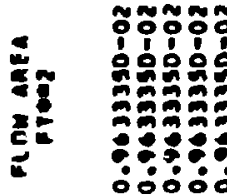

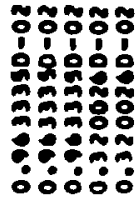

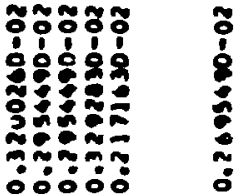

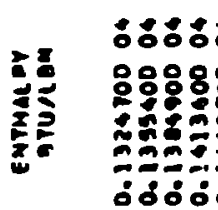

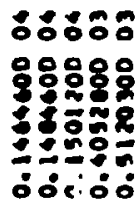

ำดวำ:

용요용

우우ํ츨

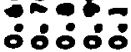

ํํํํำ

ตำ:영

ธะ์:ํ:

8880

$2983 R$

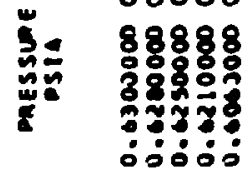

ㅇㅇㅇㅇㅛ

두융요

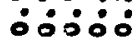


站
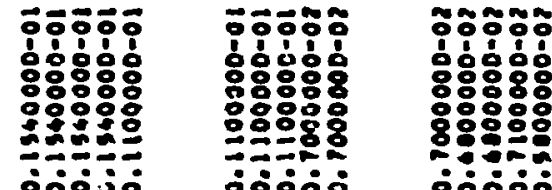

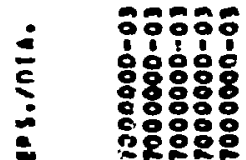

ojojo:
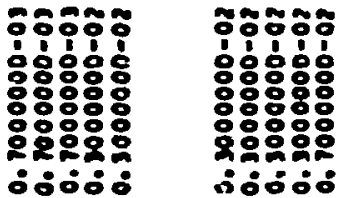

势
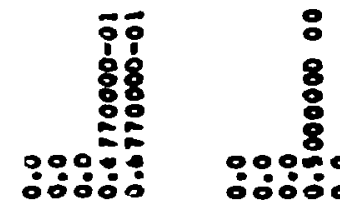

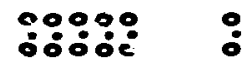

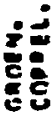

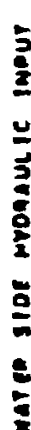

$\underline{\underline{a}}$

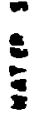

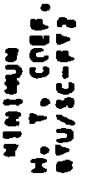
i̊ํํ이 츠르 ำำำำ :
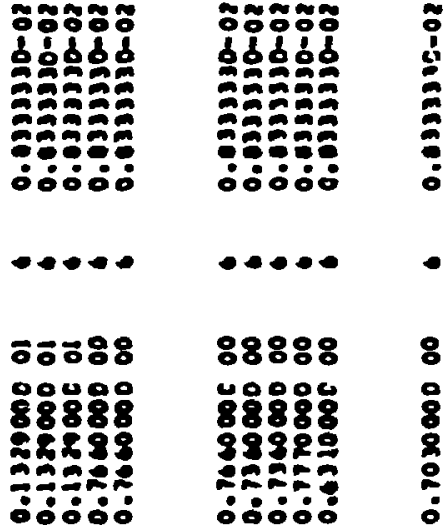

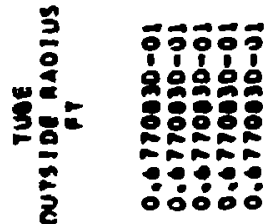

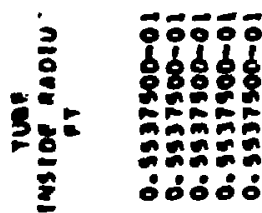

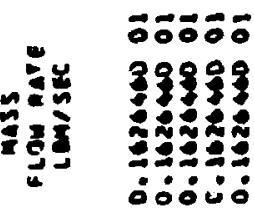
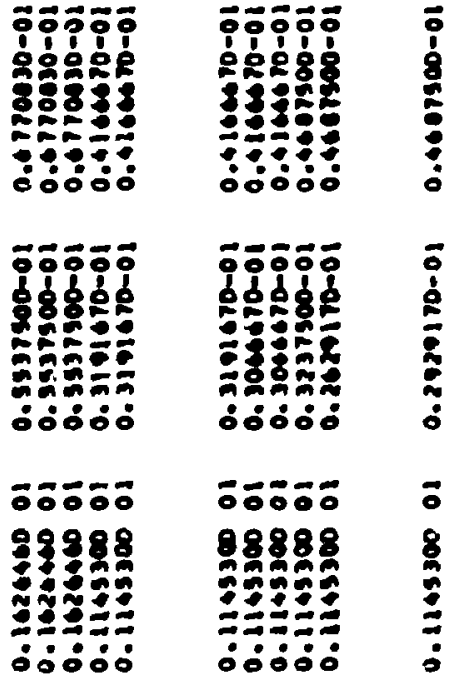

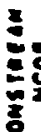<smiles>C1C[C@H]2C[C@H]1C2</smiles>

$\rightarrow \frac{0}{\infty}=$

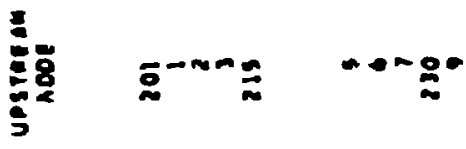

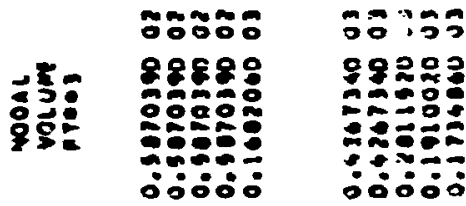

造

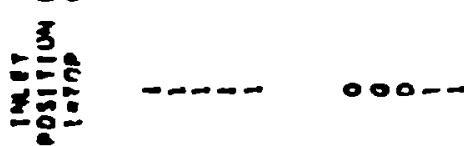

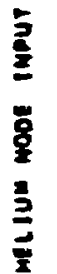

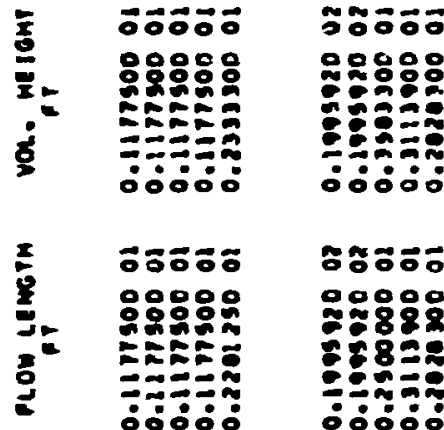

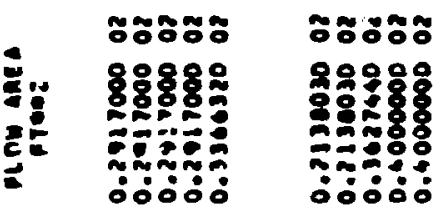

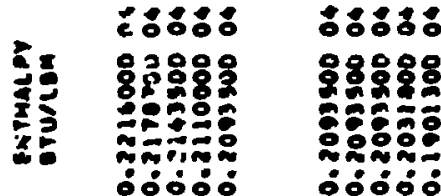

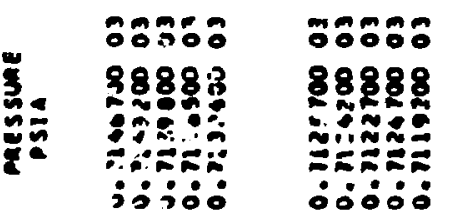




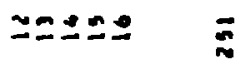

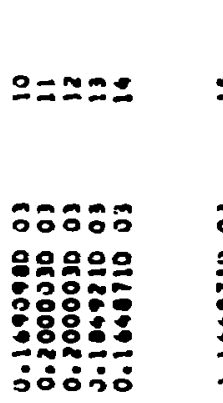

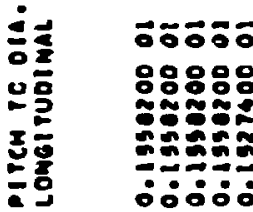

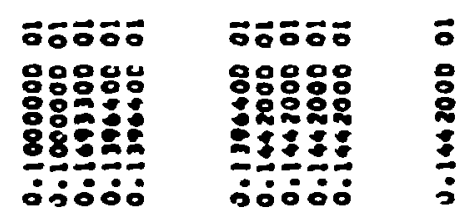

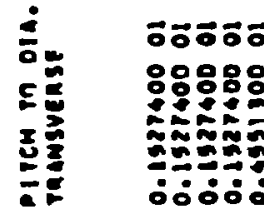

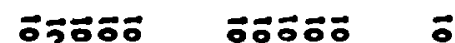

ํํㅇㅇㅛ 용요

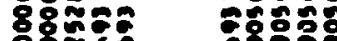

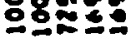

$= \pm$

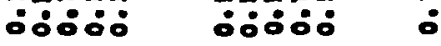

$00000 \quad 0$

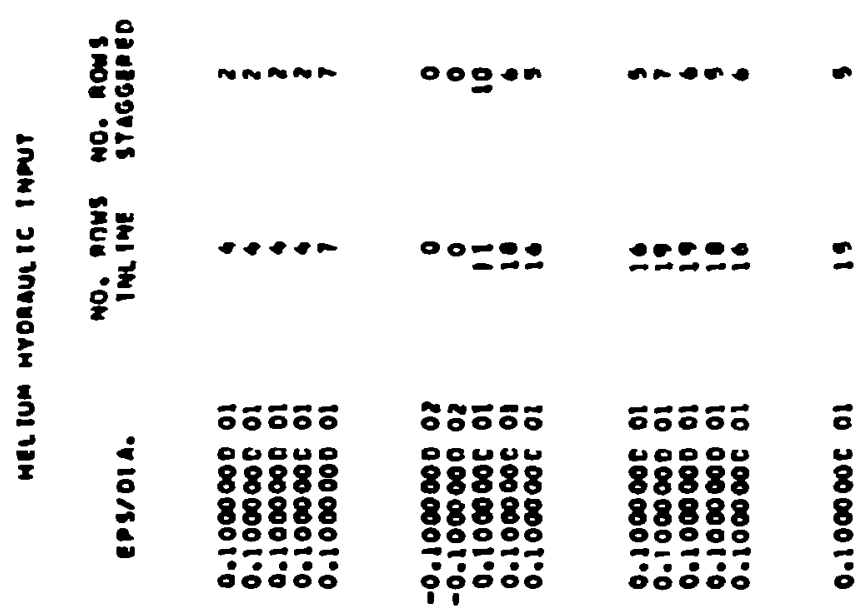

용ㅇㅇ영

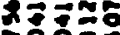

$\pi$

ํㅜㄹ

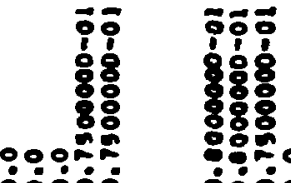

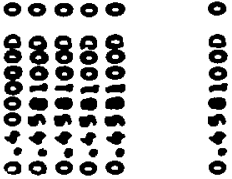

เ์ะ์ะ์ ช

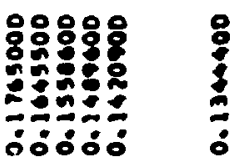

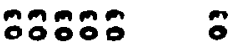

$88888 \quad 8$

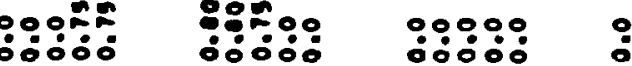

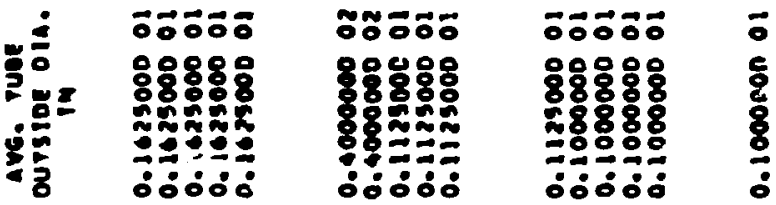

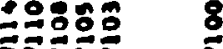

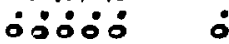

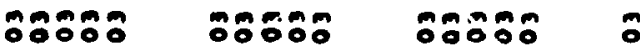

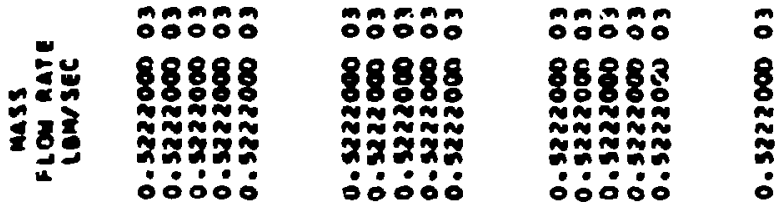




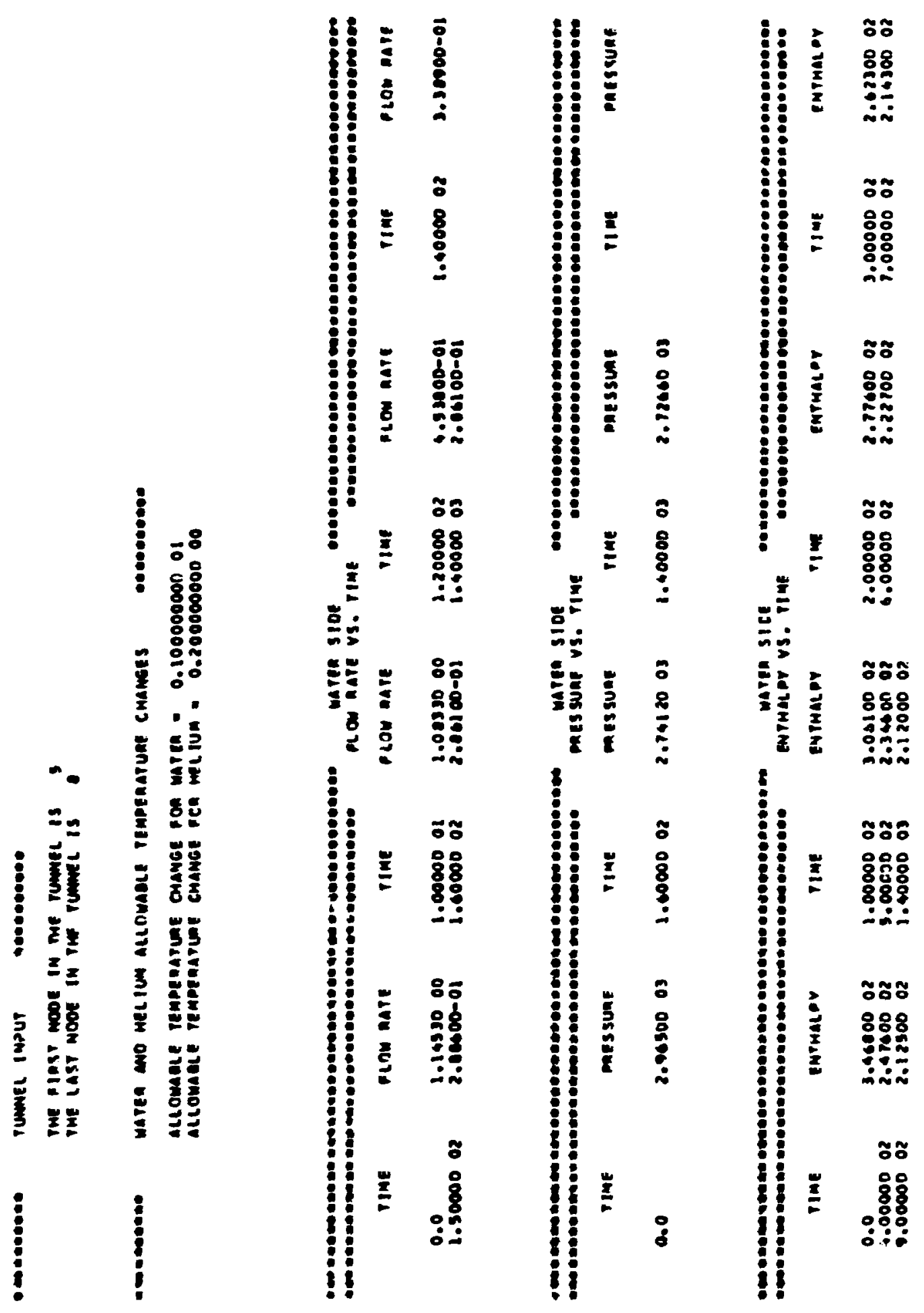



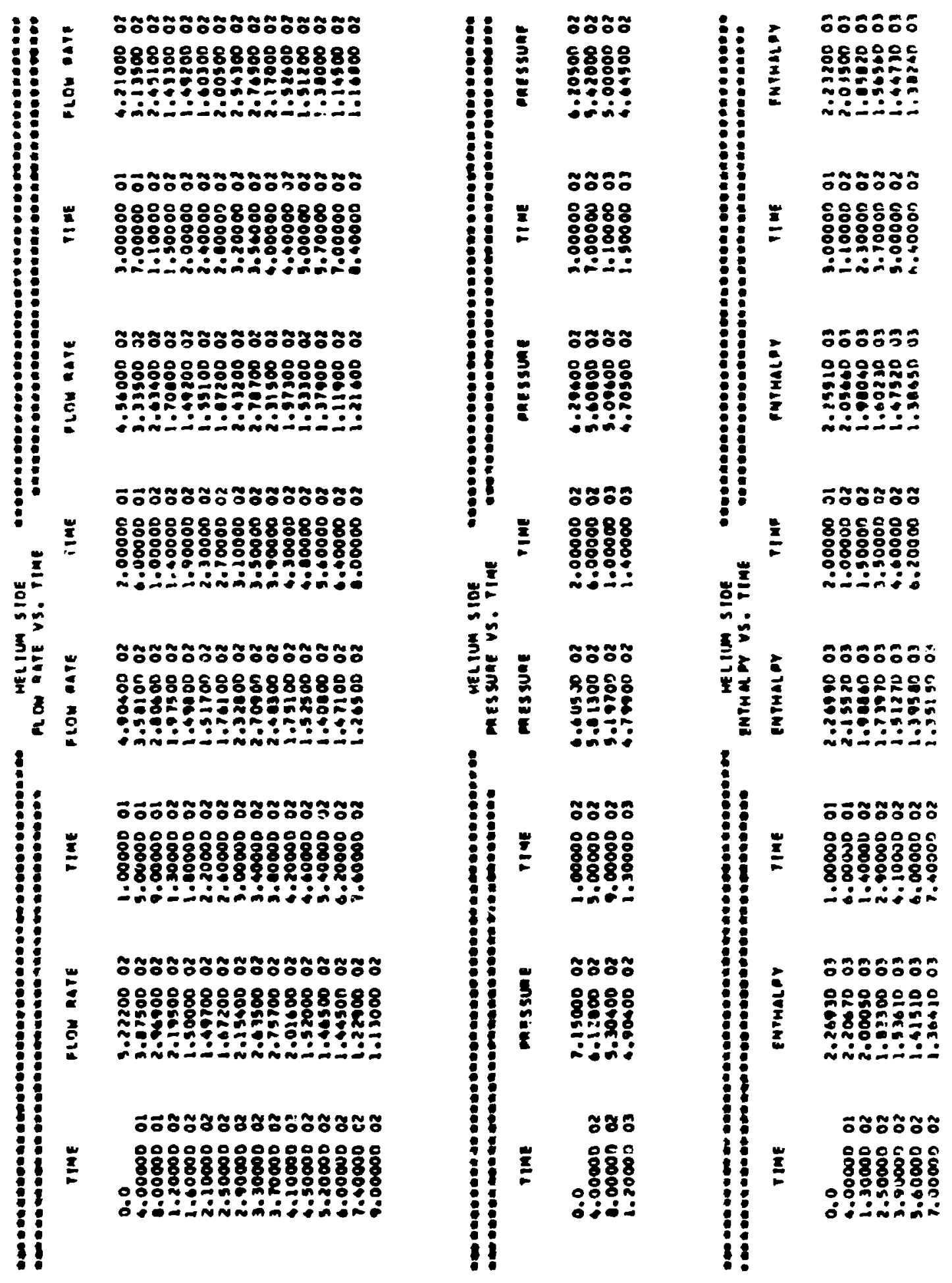


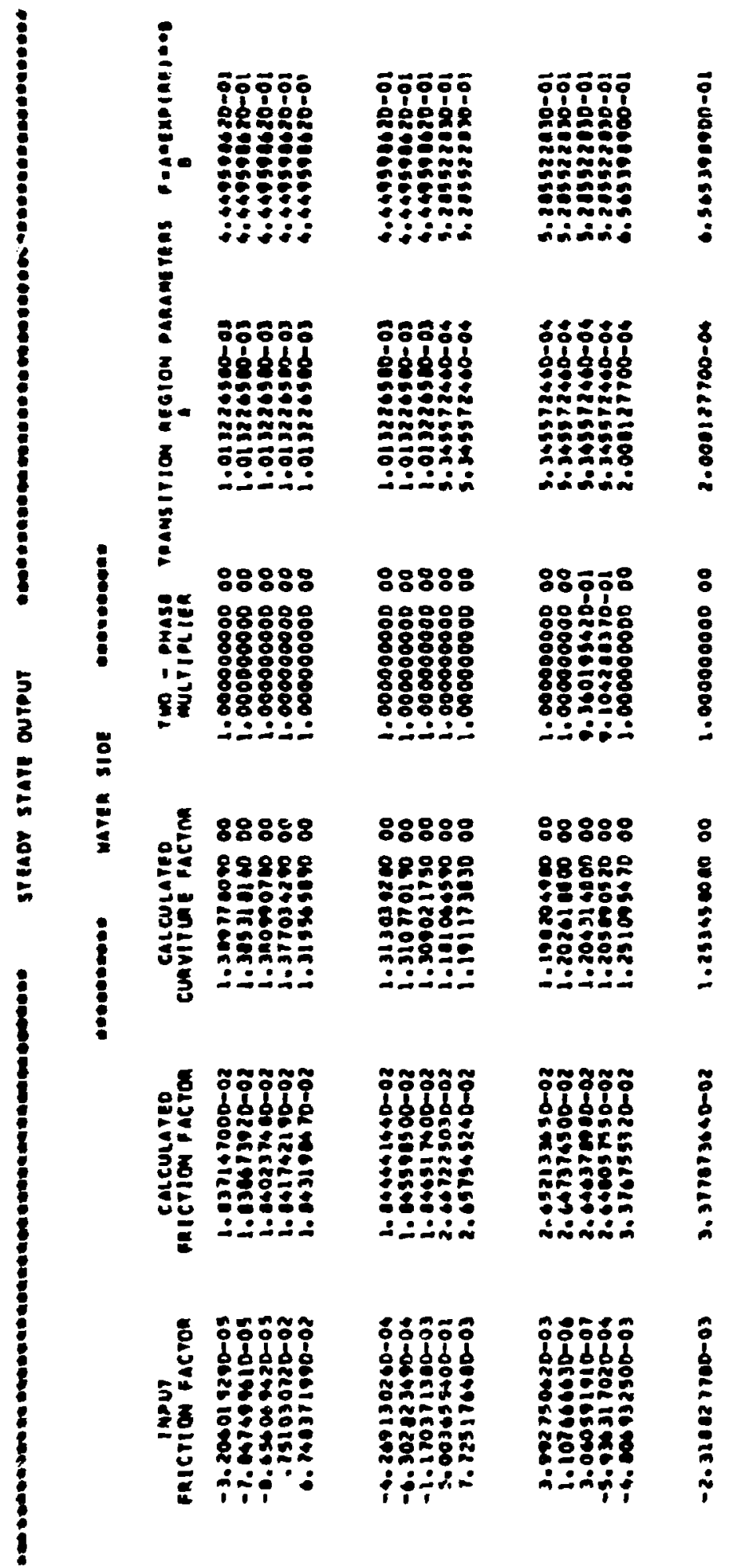




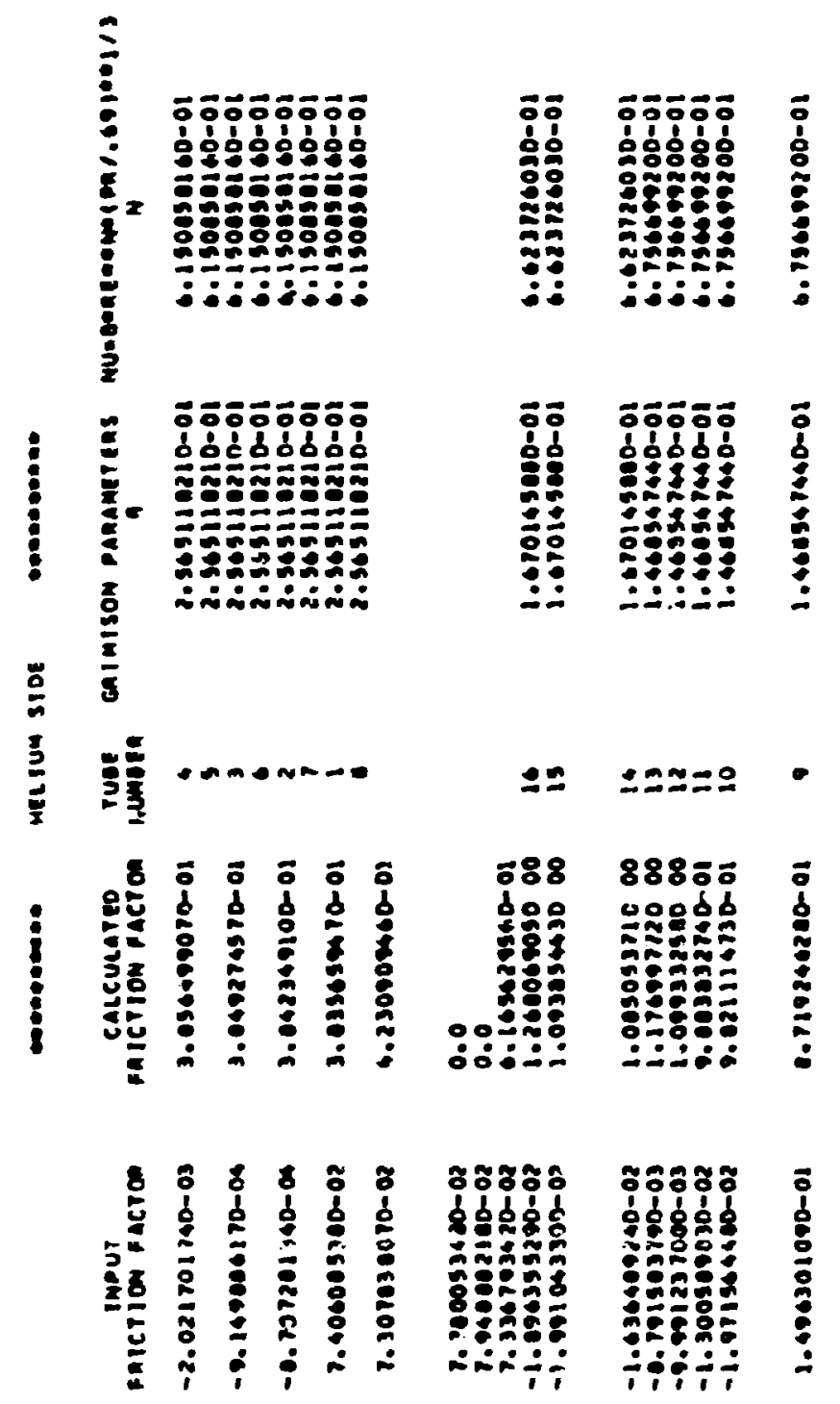




\begin{tabular}{|c|c|c|c|c|c|c|c|c|c|c|}
\hline MUE & $\begin{array}{c}\text { Daessuas } \\
\text { psta }\end{array}$ & inial mass & 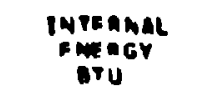 & $\begin{array}{l}\text { Iemp. } \\
\text { Dig. }\end{array}$ & DuAlity & $\begin{array}{l}\text { mass } \\
+ \text { Low hare } \\
\text { towsec }\end{array}$ & 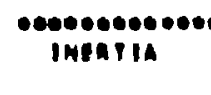 & 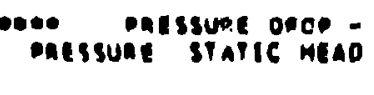 & 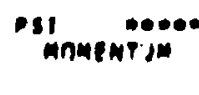 & "enicilon \\
\hline $\begin{array}{l}1 \\
3 \\
3 \\
5\end{array}$ & $\begin{array}{l}029.10 \\
226.25 \\
026 . ? 7 \\
010.09 \\
002.99\end{array}$ & $\begin{array}{l}4.719300-02 \\
6,411000-02 \\
6,201230-02 \\
3.963510-02 \\
3.41930-02\end{array}$ & 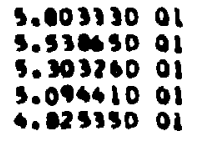 & 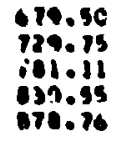 & $\begin{array}{l}1.11 \\
1.22 \\
1.18 \\
1.30 \\
1.39\end{array}$ & $\begin{array}{l}1.12444000 \\
1.12440000 \\
1.62446000 \\
1.02444000 \\
1.024400 \text { on }\end{array}$ & $\begin{array}{r}2.00210-13 \\
3.32500-13 \\
6.09250-12 \\
-7.50910-14 \\
2.6530-11\end{array}$ & 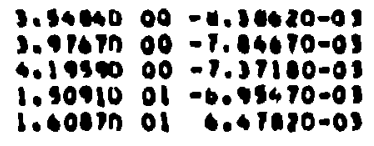 & $\begin{array}{l}-1.92330-01 \\
-4,12940-01 \\
-4,13000-01 \\
-9.09370-01 \\
-5,12230-01\end{array}$ & 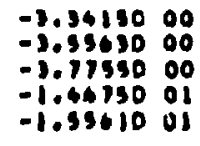 \\
\hline$\frac{1}{7}$ & $\begin{array}{r}500.90 \\
582.00 \\
578.28 \\
2061.59 \\
2790.22\end{array}$ & $\begin{array}{l}3.455960-02 \\
3.321050-02 \\
3.211540-02 \\
6.54360900 \\
3.5050 \% 000\end{array}$ & 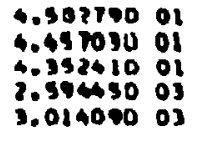 & $\begin{array}{l}920.04 \\
930.06 \\
90.36 \\
98.31 \\
324.32\end{array}$ & $\begin{array}{r}1.39 \\
1.39 \\
1.69 \\
-1.44 \\
-0.09\end{array}$ & $\begin{array}{l}1.024440 \\
1.123440 \\
1.126450 \\
1.1+5300 \\
1.1+530000 \\
00\end{array}$ & $\begin{array}{l}-9.00000-12 \\
3.04609-11 \\
1.66094-19 \\
1.06900-14 \\
0.0\end{array}$ & 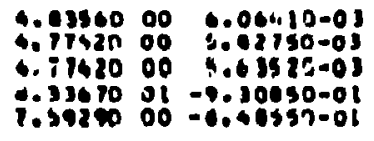 & $\begin{array}{l}-3.10340-01 \\
-3.30940-01 \\
-3.96310001 \\
-2.0540002 \\
-5.01000-02\end{array}$ & $\begin{array}{l}-4.3114000 \\
-4.44310000 \\
-4.4854000 \\
-6.26100 \\
-0.6047000\end{array}$ \\
\hline $\begin{array}{l}11 \\
12 \\
13 \\
16 \\
15\end{array}$ & $\begin{array}{l}2790.0 .3 \\
2797.08 \\
2710.43 \\
2750.50 \\
2727.00\end{array}$ & 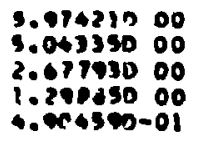 & $\begin{array}{l}3.60136003 \\
3.53517003 \\
2.19543003 \\
1.26794003 \\
3.55192002\end{array}$ & $\begin{array}{l}602,00 \\
604.17 \\
603.35 \\
602.27 \\
100.09\end{array}$ & $\begin{array}{l}-0.54 \\
-0.14 \\
0.21 \\
0.81 \\
1.31\end{array}$ & $\begin{array}{l}1.14530000 \\
1: 1+530000 \\
1.14530000 \\
1.1+530000 \\
1.14530000\end{array}$ & $\begin{array}{r}3.32200-12 \\
1.13070-15 \\
-3.35270-15 \\
0.0 \\
-3.90000-11\end{array}$ & 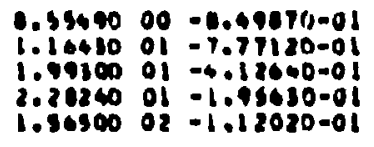 & $\begin{array}{l}-1.00000-02 \\
-8.46390-01 \\
-7.109+0-01 \\
-8.94960-01 \\
-1.9721000\end{array}$ & 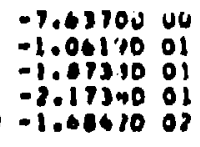 \\
\hline$\omega$ & 2511.10 & 4. 34002001 & 9.331610002 & 938.97 & 1.90 & 1.14530000 & $-1.10540-15$ & $1.9450002-0.02290-08$ & $2.30970-02$ & $-1,5464002$ \\
\hline
\end{tabular}




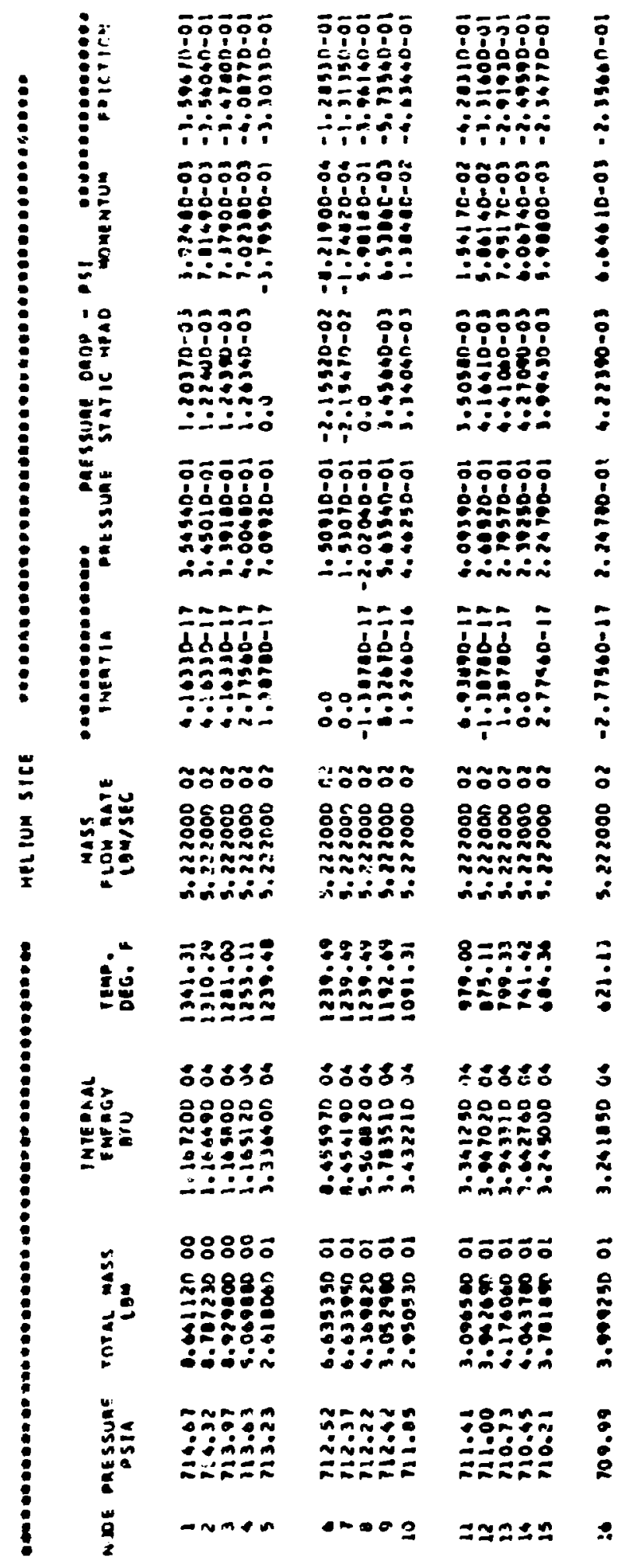




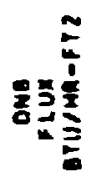

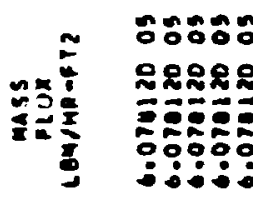

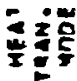

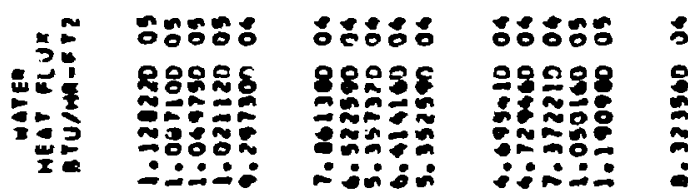

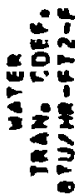

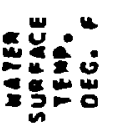

葛

$\therefore=5 \approx$ 8.8.8

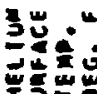

-738:0

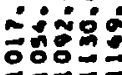

\section{กักับ}

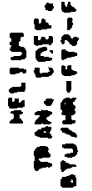

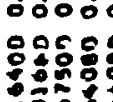
อง

aning

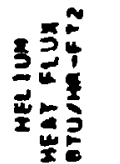

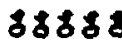

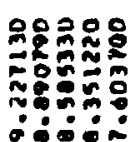

กาM

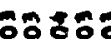

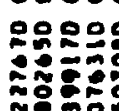

กร.ำ

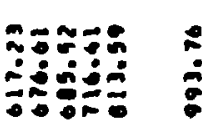

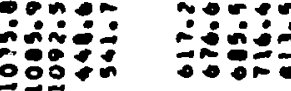

กละกละ

$\bar{Z}:=0$ ถ

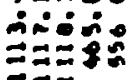

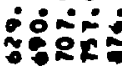

$\stackrel{\circ}{\dot{3}}$

Fะพะก

กำ

69:2 $=$

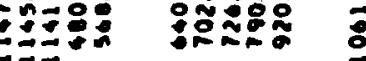

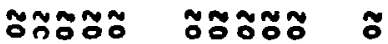

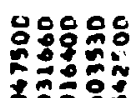

are

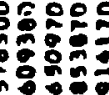

iniming

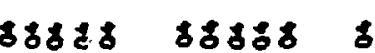

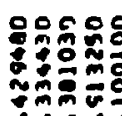

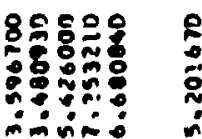

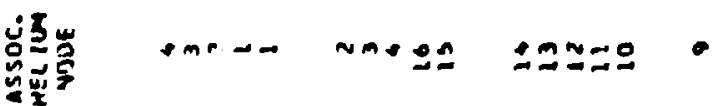

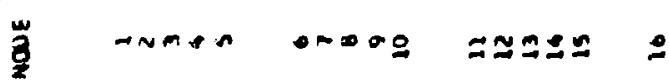

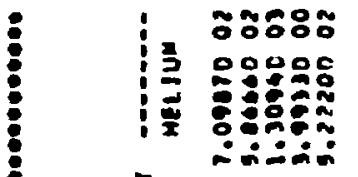

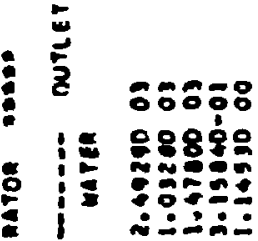

핳

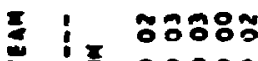

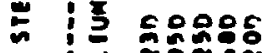

垔

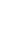

$\underline{z}$

กะก๊กัะ

i

ร

:

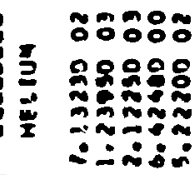

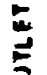

กิธิตำ

门

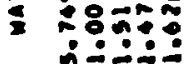

$\exists$

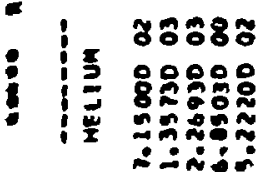

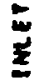

ธะระดำ

1. ระoำ

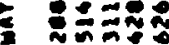

:i二-

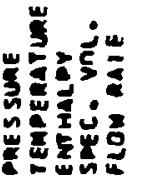




\begin{tabular}{|c|c|c|c|c|c|c|c|c|c|c|c|}
\hline NODE & $\begin{array}{l}\text { PRE SSURE } \\
\text { o SIA }\end{array}$ & roral. mass & 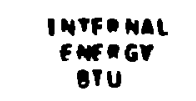 & $\begin{array}{l}\text { IEAND. } \\
\text { DEG. }\end{array}$ & Wat ITY & $\begin{array}{l}\text { mass } \\
\text { rlnm Rate } \\
\text { lom/sec }\end{array}$ & 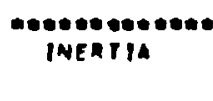 & onessung & $\begin{array}{l}\text { "suaf onar - } \\
\text { STATIC MEAD }\end{array}$ & "si momenYüe. & mocerienen \\
\hline $\begin{array}{l}1 \\
2 \\
3 \\
5 \\
5\end{array}$ & $\begin{array}{l}152.61 \\
151.99 \\
151.14 \\
150.24 \\
1+7.04\end{array}$ & $\begin{array}{l}2.093590-02 \\
1.02970-02 \\
9.767930-03 \\
9.329570-03 \\
0.027570-03\end{array}$ & 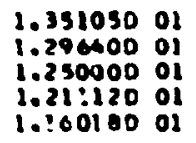 & $\begin{array}{l}664.32 \\
121.47 \\
710.22 \\
926.90 \\
667.12\end{array}$ & $\begin{array}{l}1.19 \\
1.22 \\
1.25 \\
1.28 \\
1.31\end{array}$ & $\begin{array}{l}3.636920-01 \\
3.660170-01 \\
3.669340-01 \\
3.670450-01 \\
3.671500-01\end{array}$ & $\begin{array}{l}-1.26410-03 \\
-6.46060-04 \\
-6.16460-04 \\
-1.38390-03 \\
-1.46340-03\end{array}$ & $\begin{array}{l}6.6933 n-01 \\
8.62900-01 \\
8.12000-01 \\
3.2210000 \\
3.3980000\end{array}$ & $\begin{array}{r}-1.91690-03 \\
-1.006110-03 \\
-1.71400-03 \\
-1.03700-03 \\
1.54900-03\end{array}$ & $\begin{array}{r}2.99050-02 \\
-9.35730-02 \\
-1.77720-62 \\
-1.11930-02 \\
-0.99610-02\end{array}$ & $\begin{array}{l}=7.14560-31 \\
=7.36250-01 \\
-8.00070-01 \\
=3.1496000 \\
-3.3017000\end{array}$ \\
\hline $\begin{array}{c}6 \\
7 \\
8 \\
9 \\
10\end{array}$ & $\begin{array}{l}143.65 \\
142.68 \\
141.73 \\
2624.18 \\
2610.23\end{array}$ & $\begin{array}{l}6.401860-03 \\
6.10000-03 \\
0.026390-03 \\
6.13263000 \\
6.069600\end{array}$ & $\begin{array}{l}1.115100 \text { ol } \\
1.094610 \text { ol } \\
1.079500 \text { ol } \\
2.381020 \text { 03 } \\
2.948970 \text { o3 }\end{array}$ & $\begin{array}{l}994.52 \\
910.20 \\
933.01 \\
305.21 \\
\text { s06.01 }\end{array}$ & $\begin{array}{r}1.32 \\
1.35 \\
1.35 \\
-1.16 \\
-0.15\end{array}$ & $\begin{array}{l}3.672500-01 \\
3.673490-01 \\
3.674490-01 \\
2.051330-01 \\
2.050140-01\end{array}$ & $\begin{array}{r}-1.15700-04 \\
-7.02220-04 \\
3.67810-02 \\
1.97440-04 \\
-1.34540-03\end{array}$ & $\begin{array}{l}9.73100-01 \\
9.51000-01 \\
9.71060-01 \\
5.92640 \text { o0 } \\
1.2110000\end{array}$ & $\begin{array}{r}1.47630-03 \\
1.43670-03 \\
1.40640-03 \\
-9.57740-01 \\
-0.63430-01\end{array}$ & $\begin{array}{l}-1.48240-02 \\
-4.64020-02 \\
-3.69610-02 \\
-1.34230-03 \\
-3.37410-03\end{array}$ & $\begin{array}{l}-8.40600-01 \\
-9.06910-01 \\
-9.04950-01 \\
-4.9671000 \\
-4.05970-01\end{array}$ \\
\hline $\begin{array}{l}11 \\
12 \\
13 \\
14 \\
15\end{array}$ & $\begin{array}{l}2616.96 \\
2615.42 \\
2616.16 \\
2012.75 \\
2611.74\end{array}$ & $\begin{array}{l}0.1956 \pi 00 \\
5.5923700 \\
4.92704000 \\
2.56742000 \\
1.802490-01\end{array}$ & 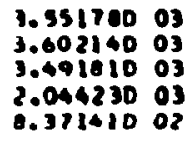 & $\begin{array}{l}579.42 \\
629.50 \\
665.60 \\
674.63 \\
674.51\end{array}$ & $\begin{array}{l}-0.49 \\
-0.27 \\
0.07 \\
0.22 \\
0.15\end{array}$ & $\begin{array}{l}2.832400-01 \\
2.847790-01 \\
2.625060-01 \\
2.694070=01 \\
2.639010-01\end{array}$ & $\begin{array}{r}3.28110-03 \\
4.62000-03 \\
-5.46990-03 \\
2.10990-03 \\
6.07170-04\end{array}$ & 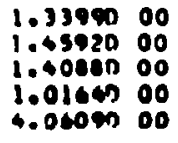 & $\begin{array}{r}-0.01310-01 \\
-0.611110-01 \\
-7.59200-01 \\
-3.16110-01 \\
3.01040-01\end{array}$ & $\begin{array}{l}-3.4106 c-c 3 \\
-1.11630-02 \\
-5.15190-03 \\
-1.66211-02 \\
-2.3990 r-01\end{array}$ & $\begin{array}{l}-4.311020-01 \\
-5.81670-01 \\
-6.49940-01 \\
-6.111000-01 \\
-3.6190000\end{array}$ \\
\hline 1 & 2007.67 & $0.228100-01$ & 1.10722002 & 66.04 & 1.45 & $024090-01$ & . $35690-03$ & $020 \pi 0$ & $14600-01$ & . & -9.4259000 \\
\hline
\end{tabular}


-

\begin{tabular}{|c|c|c|c|}
\hline NODE & $\begin{array}{l}\text { PaE s sune } \\
\text { - sia }\end{array}$ & $\begin{array}{c}\text { Poral mass } \\
\text { Lom }\end{array}$ & $\begin{array}{l}\text { InTenwal } \\
\text { enengy } \\
\text { oru }\end{array}$ \\
\hline $\begin{array}{l}1 \\
2 \\
3 \\
5 \\
5\end{array}$ & $\begin{array}{l}629.50 \\
629.66 \\
629.43 \\
629.40 \\
629.37\end{array}$ & $\begin{array}{l}.045310000 \\
9.15652000 \\
9.26650000 \\
. .37025000 \\
2.70331001\end{array}$ & $\begin{array}{l}1.02762004 \\
1.02740004 \\
1.02734004 \\
1.02720004 \\
2.042950 \text { o4 }\end{array}$ \\
\hline $\begin{array}{l}: \\
10\end{array}$ & $\begin{array}{l}629.31 \\
629.27 \\
629.24 \\
629.25 \\
629.20\end{array}$ & 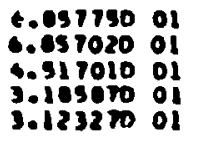 & 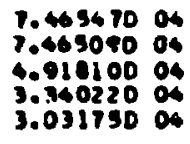 \\
\hline $\begin{array}{l}11 \\
12 \\
13 \\
14\end{array}$ & $\begin{array}{l}629.16 \\
629.13 \\
629.10 \\
429.01 \\
629.06\end{array}$ & $\begin{array}{l}3.243620 \text { ol } \\
3.904760 \text { ol } \\
4.024450 \text { ol } \\
3.909035 \text { ol } \\
3.631950 \text { ol }\end{array}$ & $\begin{array}{l}2.933200 \\
3.491460 \\
3.4904 \\
3.490404 \\
3.226010 \text { O4 } \\
2.874660 \text { O4 }\end{array}$ \\
\hline & & $3.0605 m^{3} 01$ & 1269004 \\
\hline
\end{tabular}

1053.67
1030.48
1030.51

1000.70 Q1.

ขอ1.

921.08

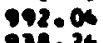

934.24

100.59

670.94

$4+0.13$

9.1

330.40

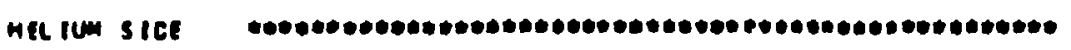

mass

- coescogesecoseso

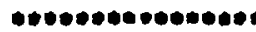
remp. FLOM RATE

inentila

pressune static head monentum

Beicrion Low/sec

\section{$\begin{array}{lll}1.491940 & 02 & 1.28430-07 \\ 1.491970 & 02 & 4.37610-07\end{array}$}

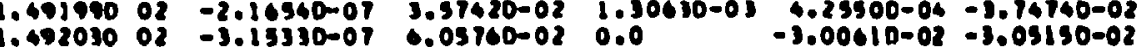

$1.49215002-2.30470-07 \quad 3.24430-02-2.12740-02-1.63990-05-1.01540-02$ $1.49227002 \quad-2.97690-07 \quad 3.26670-02-2.22720-02-1.14060-03-1.03770-02$ $1.49233002-1.02570-07-1.06050-020.0 \quad 4.16290-02-3.60240-02$

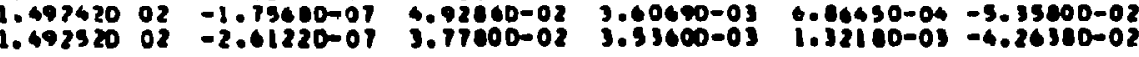

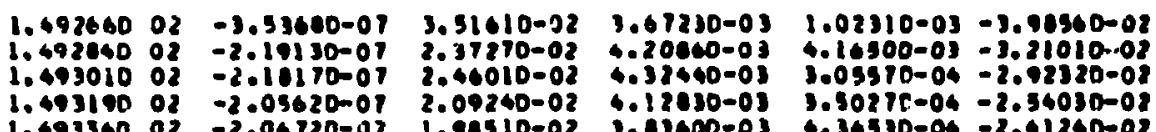

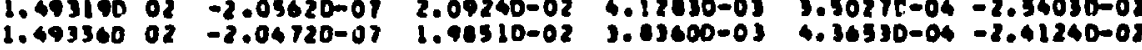

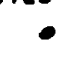

$1.49353002 \quad 7.71990-03 \quad 2.63490-02 \quad 4.00590-03 \quad 0.34740-04-2.33300-08$ 


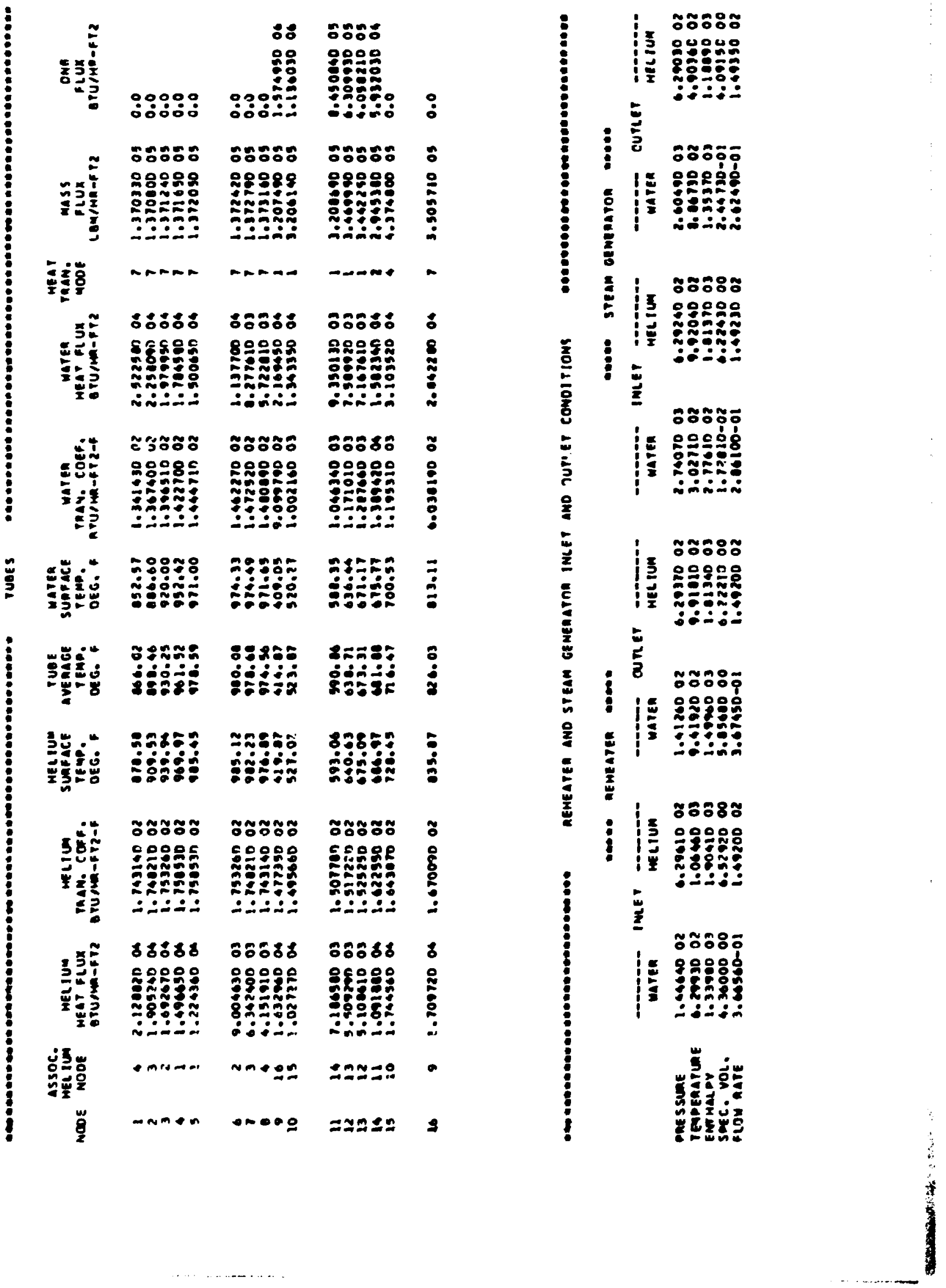




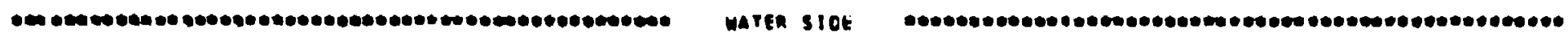

\begin{tabular}{|c|c|c|c|c|c|c|c|c|c|c|}
\hline NODE & $\begin{array}{l}\text { menssuaf } \\
\text { osia }\end{array}$ & rntal mass & 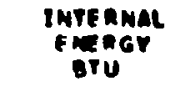 & $\begin{array}{l}\text { remo. } \\
\text { OEg.: }\end{array}$ & OUALITY & $\begin{array}{l}\text { mass } \\
\text { romenare } \\
\text { com/sec }\end{array}$ & 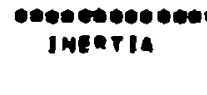 & 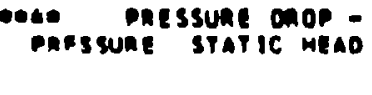 & PI momentum & 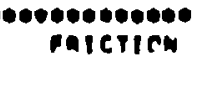 \\
\hline $\begin{array}{l}1 \\
2 \\
3 \\
4 \\
5\end{array}$ & $\begin{array}{l}32.09 \\
32.67 \\
52.40 \\
32.14 \\
31.17\end{array}$ & $\begin{array}{l}4.070450-93 \\
3.934750-03 \\
3.024340-03 \\
3.730350-03 \\
3.020410-03\end{array}$ & $\begin{array}{l}4.91970000 \\
4.99450000 \\
.09502000 \\
4.01605000 \\
4.49156000\end{array}$ & $\begin{array}{l}592.14 \\
613.36 \\
636.40 \\
453.52 \\
64.96\end{array}$ & $\begin{array}{l}1.16 \\
1.17 \\
1.18 \\
1.20 \\
1.20\end{array}$ & $\begin{array}{l}1.270900-01 \\
1.271240-01 \\
1.271510-01 \\
1.271770-01 \\
1.272020-01\end{array}$ & $\begin{array}{l}-1.31690-04 \\
-1.44100-04 \\
-1.46050-04 \\
-2.69610-04 \\
-2.17510-04\end{array}$ & 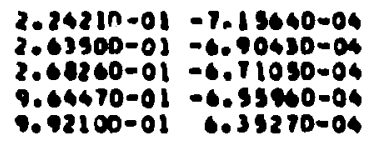 & 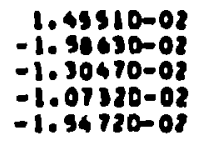 & $\begin{array}{l}30170-01 \\
67090-01 \\
34690-01 \\
53950-01 \\
71540-01\end{array}$ \\
\hline$:$ & $\begin{array}{r}50.16 \\
49.90 \\
49.62 \\
2017.63 \\
2011.79\end{array}$ & $\begin{array}{l}3.513140-03 \\
3.464700-03 \\
3.424670-03 \\
6.07013000 \\
6.12035000\end{array}$ & $\begin{array}{l}4.37436000 \\
4.32433000 \\
4.29332000 \\
2.1940003 \\
2.91271003\end{array}$ & $\begin{array}{l}672.52 \\
678.73 \\
640.05 \\
352.43 \\
497.53\end{array}$ & $\begin{array}{r}1.21 \\
1.22 \\
1.22 \\
-1.26 \\
-0.70\end{array}$ & $\begin{array}{l}1.272770-01 \\
2.272520-01 \\
1.272760-01 \\
2.032100-01 \\
2.027320-01\end{array}$ & $\begin{array}{r}-1.53630-04 \\
-1.53670-04 \\
-1.12280-03 \\
-1.86700-02 \\
-.90690-02\end{array}$ & 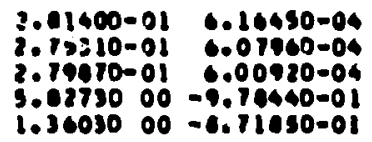 & $\begin{array}{l}9060-02 \\
17090-03 \\
12060-03 \\
3900-03 \\
13430-03\end{array}$ & $\begin{array}{l}-2.00 \\
-2.06 \\
-4.86 \\
-3.05\end{array}$ \\
\hline $\begin{array}{l}11 \\
12 \\
13 \\
16 \\
15\end{array}$ & $\begin{array}{l}2010.42 \\
2609.16 \\
2607.61 \\
2006.41 \\
2605.30\end{array}$ & $\begin{array}{l}6.16202000 \\
3.39601000 \\
3.19312000 \\
1.55102000 \\
2.96310000\end{array}$ & $\begin{array}{l}3.55537003 \\
3.40169003 \\
3.5539003 \\
3.232300 \text { 03 } \\
3.145450 \text { 03 }\end{array}$ & $\begin{array}{l}502.03 \\
630.12 \\
633.05 \\
686.11 \\
673.06\end{array}$ & $\begin{array}{l}-0.47 \\
=0.27 \\
=0.14 \\
=0.06 \\
0.01\end{array}$ & $\begin{array}{l}2.703220-01 \\
2.736390-01 \\
2.699030-01 \\
2.664070-01 \\
2.645500-01\end{array}$ & $\begin{array}{r}-5.79230-02 \\
-3.39670-02 \\
3.25130-02 \\
-1.53900-12 \\
2.17440-03\end{array}$ & 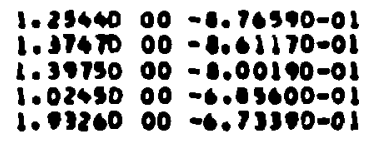 & $\begin{array}{r}-2.72500-03 \\
-9.11040-03 \\
-2.06060-03 \\
9.07100-03 \\
-3.39590-02\end{array}$ & $\begin{array}{l}-4.32620-01 \\
-5.38430-01 \\
-3.62720-01 \\
-3.62330-01 \\
-1.2024000\end{array}$ \\
\hline It & 2003.45 & 3.30610000 & $2,5 ! 910003$ & 674.10 & 0.06 & $2.446340-01$ & $1.418350-03$ & $1.3948000-6.19300-01$ & $3.13620-02$ & $-0.07320-01$ \\
\hline
\end{tabular}




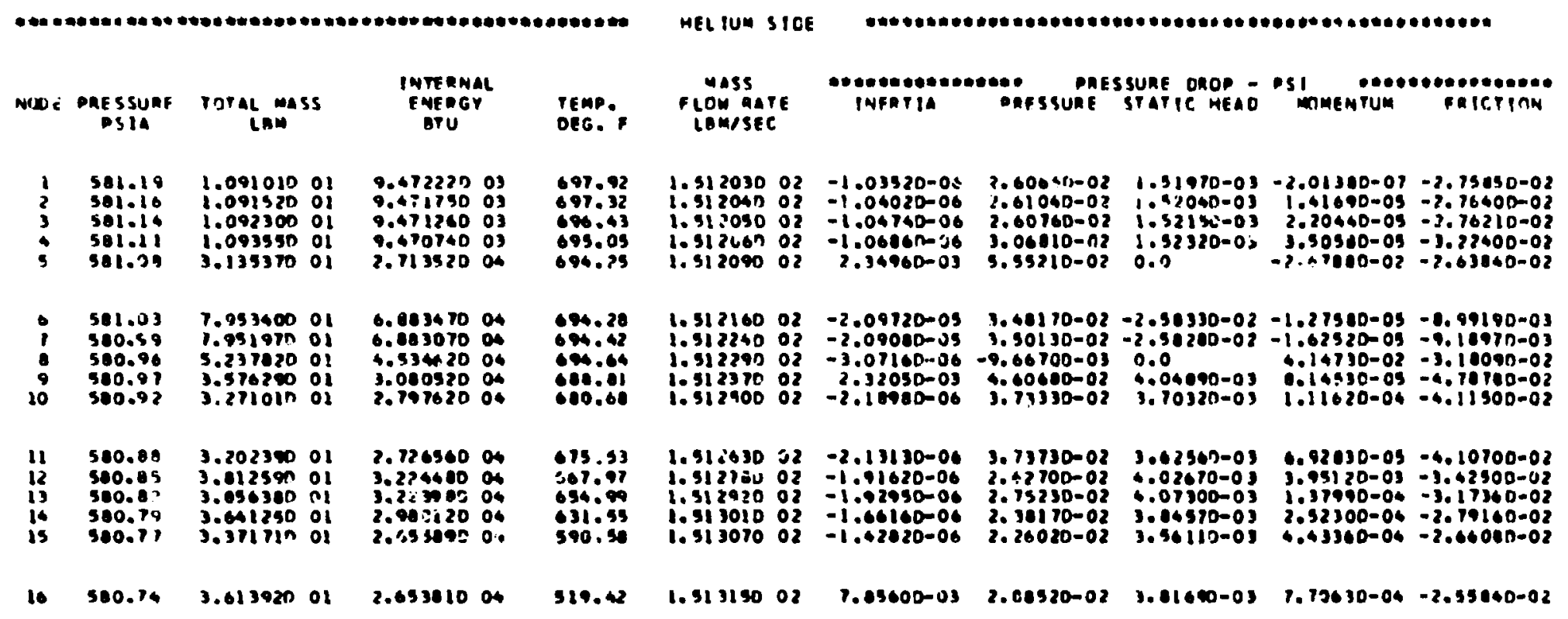


率突

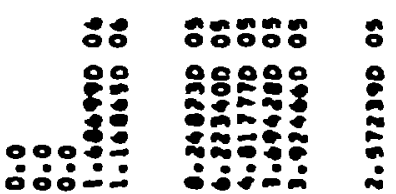

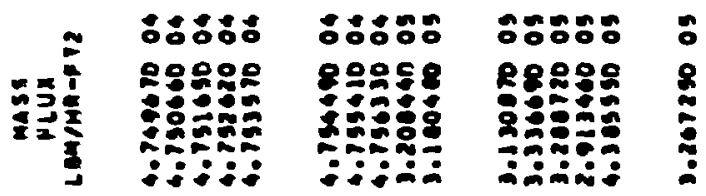

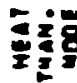

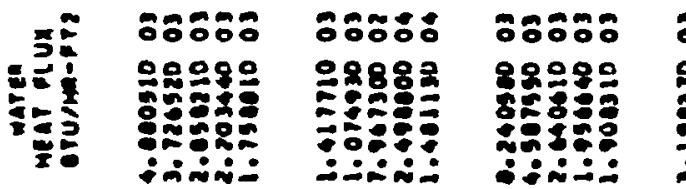

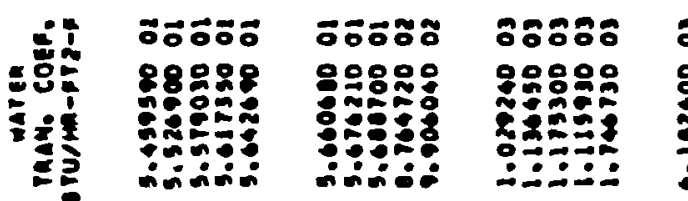

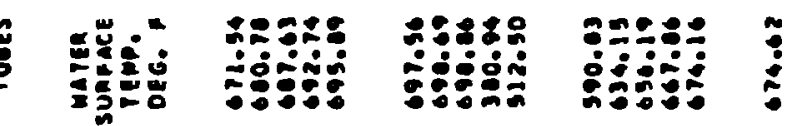

|

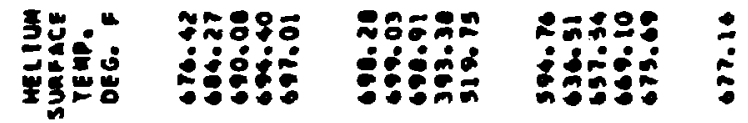

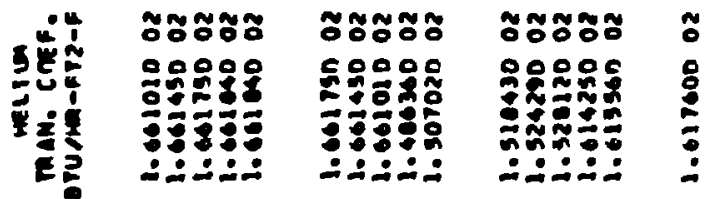

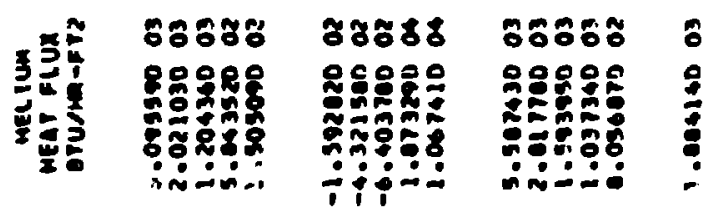

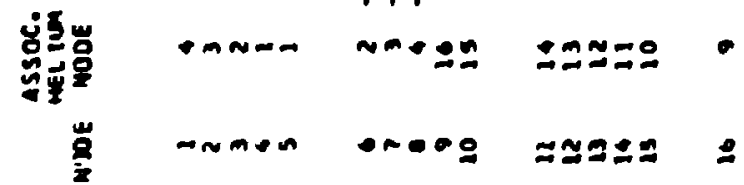

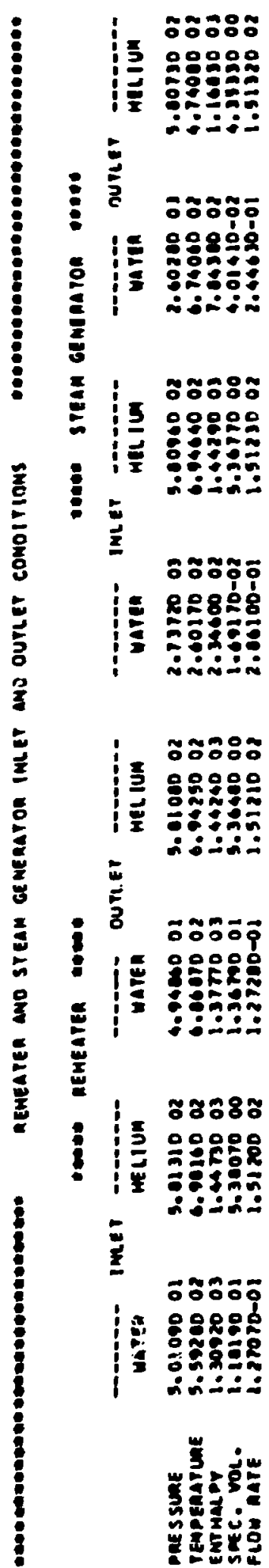




\begin{tabular}{|c|c|c|c|c|c|c|c|c|c|c|}
\hline NOOE & $\begin{array}{l}\text { PAE SSSUAE } \\
\text { - SiA }\end{array}$ & Toral mass & $\begin{array}{l}\text { INTERMAL } \\
\text { Preagr } \\
\text { OTU }\end{array}$ & $\begin{array}{l}\text { Temp. } \\
\text { Deg. }\end{array}$ & eval ITY & $\begin{array}{l}\text { mass } \\
\text { roun arfor } \\
\text { con/sec }\end{array}$ & 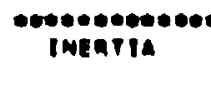 & 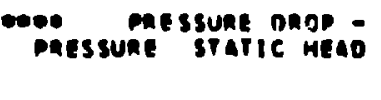 & Ds! monentum & necencenes \\
\hline $\begin{array}{l}1 \\
2 \\
3 \\
3 \\
3\end{array}$ & $\begin{array}{l}47.04 \\
46.05 \\
46.03 \\
46.40 \\
43.58\end{array}$ & $\begin{array}{l}3.730900-03 \\
3.600200-03 \\
3.500160-03 \\
3.422210-03 \\
3.310710-03\end{array}$ & $\begin{array}{r}4.46209000 \\
4.34663000 \\
1.26063000 \\
.10003000 \\
.00002000\end{array}$ & $\begin{array}{l}547 \cdot 49 \\
576 \cdot 22 \\
597.34 \\
613.34 \\
631.33\end{array}$ & $\begin{array}{l}1.14 \\
1.10 \\
1.17 \\
1.10 \\
1.10\end{array}$ & $\begin{array}{l}1.117700-01 \\
1.117000-01 \\
1.117030-01 \\
1.117070-01 \\
1.117000-01\end{array}$ & $\begin{array}{l}-2.07590-05 \\
-2.20290-05 \\
-2.24300-05 \\
-6.69050-05 \\
-3.30460-05\end{array}$ & 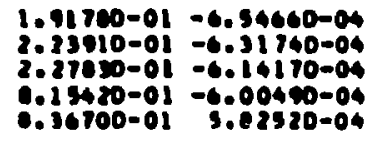 & $\begin{array}{r}1.16510-02 \\
-1.31920-02 \\
-1.07060-02 \\
-1.03420-03 \\
-1.22370-02\end{array}$ & $\begin{array}{l}-2.02010-01 \\
-2.10100-01 \\
-2.16490-01 \\
-8.06040-01 \\
-0.25000-01\end{array}$ \\
\hline$:$ & $\begin{array}{r}40.15 \\
44.31 \\
44.29 \\
2617.94 \\
2612.12\end{array}$ & $\begin{array}{l}3.234700-03 \\
3.205000-03 \\
3.103220-03 \\
6.24654000 \\
6.33321000\end{array}$ & $\begin{array}{l}3.90499000 \\
3.99304000 \\
3.92629000 \\
2.07727003 \\
2.76029003\end{array}$ & 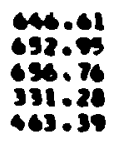 & $\begin{array}{r}1.19 \\
1.20 \\
1.20 \\
-1.32 \\
-0.90\end{array}$ & $\begin{array}{l}1.117930-01 \\
1.117980-01 \\
1.117900-01 \\
2.857500-01 \\
2.207000-01\end{array}$ & $\begin{array}{r}-2.02000-09 \\
-2.06210-09 \\
1.00200-03 \\
9.27100-03 \\
7.23430-04\end{array}$ & 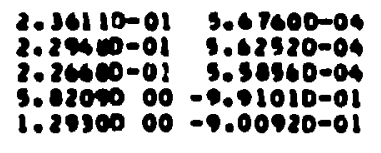 & $\begin{array}{l}-1.07440-02 \\
-3.00300-03 \\
-3.01600-03 \\
-1.21400-03 \\
-2.70150-03\end{array}$ & $\begin{array}{l}-2.25650-01 \\
-2.26860-01 \\
-2.22920-01 \\
-4.82360 .00 \\
-3.00600-01\end{array}$ \\
\hline $\begin{array}{l}11 \\
12 \\
13 \\
16 \\
13\end{array}$ & $\begin{array}{l}2010.02 \\
2009.46 \\
2000.01 \\
2000.46 \\
2005.90\end{array}$ & $\begin{array}{l}0.49401000 \\
3.97421000 \\
3.30124000 \\
3.91300000 \\
3.21070000\end{array}$ & $\begin{array}{l}3.45031003 \\
3.504950 \text { 03 } \\
3.00133009 \\
3.31301003 \\
2.22002003\end{array}$ & $\begin{array}{l}540.72 \\
399.97 \\
630.14 \\
640.16 \\
497.57\end{array}$ & $\begin{array}{l}-0.41 \\
=0.40 \\
=0.28 \\
0.17 \\
=0.12\end{array}$ & $\begin{array}{l}2.029370-2 i \\
2.797900 .01 \\
2.7647110 .01 \\
2.720390-01 \\
8.699760-01\end{array}$ & $\begin{array}{r}1.63000-02 \\
-9.39010-0.03 \\
-3.51520-02 \\
-3.11320-02 \\
3.09320-02\end{array}$ & 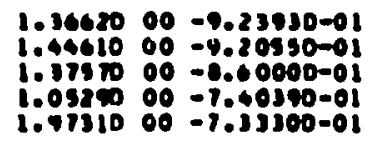 & $\begin{array}{l}-2.35150-03 \\
-8.03130-03 \\
-2.00170-03 \\
0.10000-03 \\
-9.10940-02\end{array}$ & $\begin{array}{l}-4.23430-01 \\
-5.26100-01 \\
-5.69690-01 \\
-3.31730-01 \\
-1.1690000\end{array}$ \\
\hline 16 & 2003.01 & 0.28676000 & 3.01202003 & 462.15 & -0.08 & $2.042530-01$ & $1.30440-02$ & $1.55500 \quad 00-7.00500-01$ & $3.23090-02$ & $1.02010-01$ \\
\hline
\end{tabular}




\begin{tabular}{|c|c|c|c|c|c|c|c|c|c|c|}
\hline $400 E$ & $\begin{array}{l}\text { me ssune } \\
\text { - SIA }\end{array}$ & $\begin{array}{c}\text { roral mass } \\
\text { LaW }\end{array}$ & 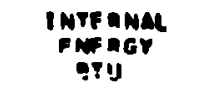 & $\begin{array}{l}\text { TEMP. } \\
\text { DEG. F }\end{array}$ & 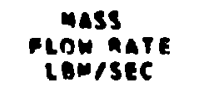 & 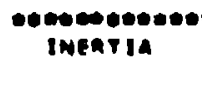 & $\begin{array}{l}\text { Panes } \\
\text { pressune }\end{array}$ & $\begin{array}{l}\text { ssune onoe } \\
\text { sravir. neno }\end{array}$ & - SI MONE MPUN" & 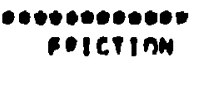 \\
\hline $\begin{array}{l}1 \\
2 \\
3 \\
4 \\
5\end{array}$ & $\begin{array}{l}500.30 \\
360.46 \\
300.63 \\
500.41 \\
500.50\end{array}$ & $\begin{array}{l}1.091370 \text { ol } \\
1.091000 \text { ol } \\
1.092510 \text { ol } \\
1.093510 \text { ol } \\
3.134000 \text { ol }\end{array}$ & $\begin{array}{l}9.13741003 \\
9.13690003 \\
9.13655003 \\
9.13600003 \\
2.01764006\end{array}$ & $\begin{array}{l}656.64 \\
654.06 \\
655.31 \\
654.27 \\
653.65\end{array}$ & 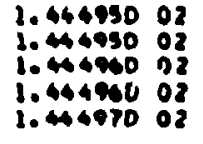 & $\begin{array}{r}2.01420-06 \\
2.00900-06 \\
2.00020-06 \\
2.00240-06 \\
-4.01000-03\end{array}$ & $\begin{array}{l}2.37420-02 \\
2.31790-02 \\
2.37610-02 \\
2.77750-02 \\
4.39550-02\end{array}$ & $\begin{array}{l}1.52020-03 \\
1.52000-03 \\
1.32100-03 \\
1.52320-03 \\
0.0\end{array}$ & $\begin{array}{r}1.01290-01 \\
1.315110-05 \\
1.63110-05 \\
8.40210-05 \\
-2.44690-02\end{array}$ & $\begin{array}{l}-2.52610-02 \\
-2.52110-02 \\
-2.52870-02 \\
-2.95820-02 \\
-2.61640-02\end{array}$ \\
\hline $\begin{array}{c}7 \\
10\end{array}$ & $\begin{array}{l}500.34 \\
300.50 \\
300.45 \\
500.49 \\
500.44\end{array}$ & $\begin{array}{l}7.937330 \text { ol } \\
7.951070 \text { ol } \\
3.237430 \text { ol } \\
3.530040 \text { ol } \\
3.217050 \text { ol }\end{array}$ & $\begin{array}{l}0.640370 \text { of } \\
6.634000 \text { of } \\
4.374460 \text { of } \\
2.971920 \text { of } \\
2.699260 \text { of }\end{array}$ & $\begin{array}{l}653.47 \\
653.71 \\
653.45 \\
656.51 \\
659.04\end{array}$ & $\begin{array}{l}1.445010 \\
1.45040 \\
1.42 \\
1.445000 \\
1.450202 \\
1.4513002\end{array}$ & $\begin{array}{r}4.34740-05 \\
4.39510-05 \\
6.25400-00 \\
-4.62840-03 \\
3.41210-06\end{array}$ & $\begin{array}{r}3.40930-02 \\
3.42720-02 \\
-6.62460-03 \\
3.39900-02 \\
3.67450-02\end{array}$ & $\begin{array}{l}-2.58300-02 \\
-2.50280-02 \\
0.0 \\
4.01820-03 \\
1.04810-03\end{array}$ & $\begin{array}{r}-1.00160-06 \\
-1.07940-05 \\
3.17650-02 \\
-3.47700-05 \\
-3.90900-05\end{array}$ & $\begin{array}{l}-0.21 \\
-8.39 \\
-2.91 \\
-6.42 \\
-3.03\end{array}$ \\
\hline $\begin{array}{l}11 \\
12 \\
13 \\
16 \\
15\end{array}$ & $\begin{array}{l}500.41 \\
540.37 \\
300.35 \\
300.32 \\
300.30\end{array}$ & $\begin{array}{l}3.142300 \text { ol } \\
3.746200 \text { ol } \\
3.001200 \text { of } \\
3.609700 \text { ol } \\
3.397120 \text { ol }\end{array}$ & 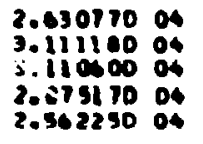 & $\begin{array}{l}456.99 \\
646.22 \\
631.39 \\
302.42 \\
557.45\end{array}$ & 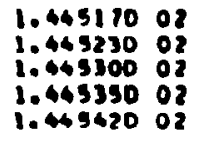 & $\begin{array}{l}3.00970-06 \\
2.92050-06 \\
2.92440-06 \\
2.73700-06 \\
2.60370-06\end{array}$ & $\begin{array}{l}3.41810-02 \\
2.43900-02 \\
2.33400-02 \\
2.17100-02 \\
2.04710-02\end{array}$ & $\begin{array}{l}3.55760-03 \\
3.95450-03 \\
4.01400-03 \\
3.91140-03 \\
3.54570-03\end{array}$ & $\begin{array}{l}3.10790-05 \\
3.6860-03 \\
1.71310-04 \\
2.93920-06 \\
4.51210-04\end{array}$ & $\begin{array}{l}-1.04070-02 \\
-3.19960-02 \\
-2.95230-02 \\
-2.58130-08 \\
-2.46770-02\end{array}$ \\
\hline & .20 & 60230001 & .56022004 & 487.93 & 04553202 & $.15400-03$ & $.+1200-02$ & $3.00400-03$ & $1.16800-04$ & $34950-c$ \\
\hline
\end{tabular}


:

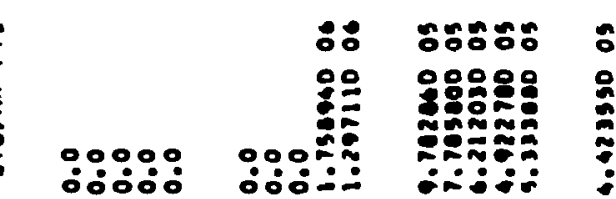

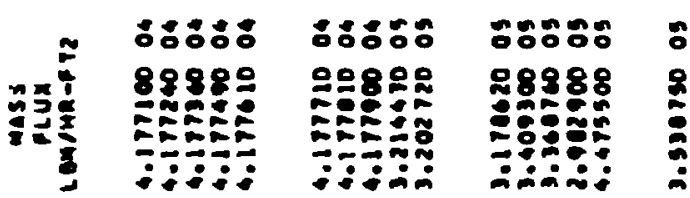

旅

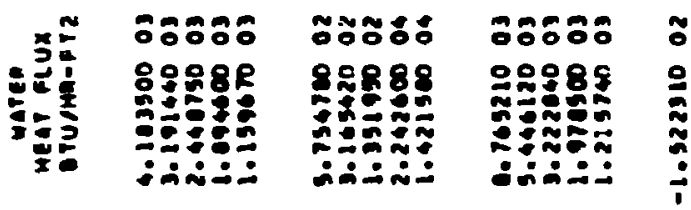

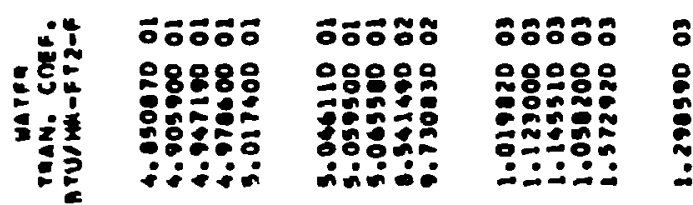

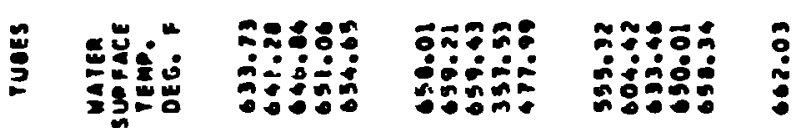

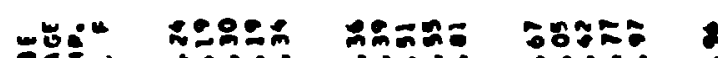

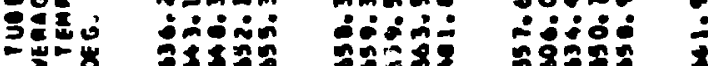

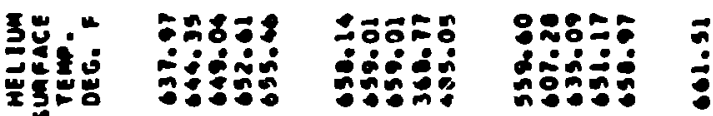

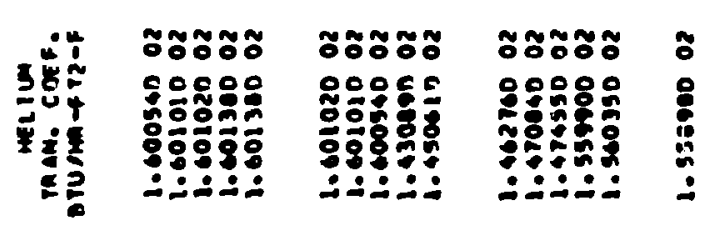

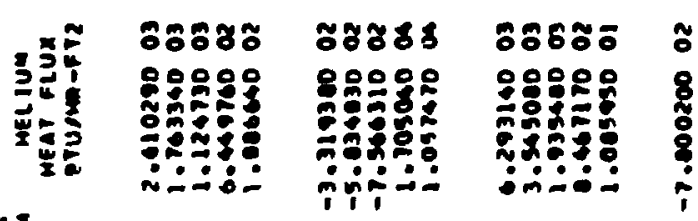

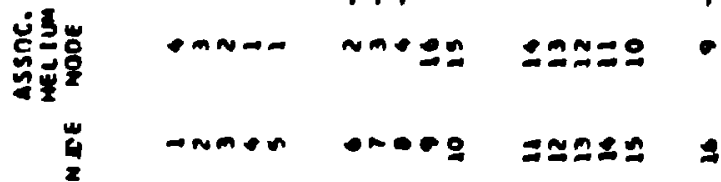

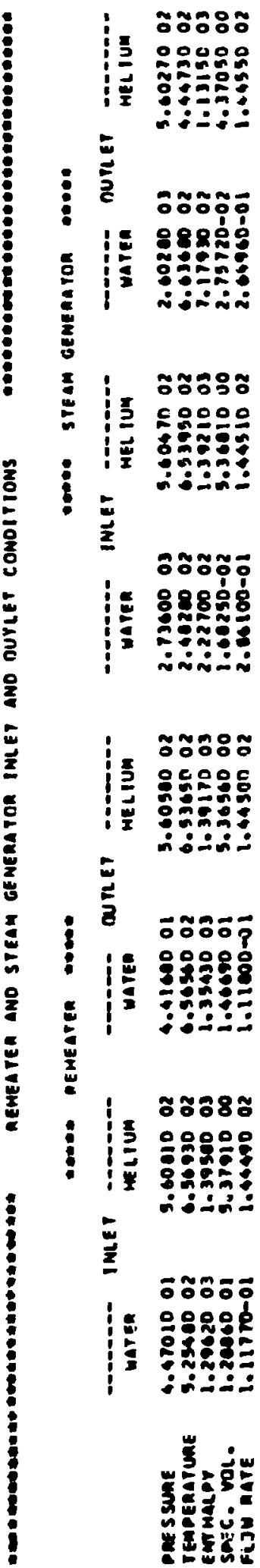

